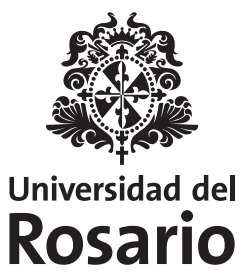





\section{ENEMISTAD POLÍTICA Y DIFERENCIA SEXUAL EN LA MASACRE DE BAHÍA PORTETE}

Retos al concepto de lo político de Carl Schmitt 


\section{Martínez Osorio Margarita María}

Enemistad política y diferencia sexual en la masacre de Bahía Portete : Retos al concepto de lo político de Carl Schmitt / Margarita María Martínez Osorio. - Bogotá: Editorial Universidad del Rosario, Escuela de Ciencias Humanas, 2015.

182 páginas. - (Colección Opera Prima)

Incluye referencias bibliográficas

ISBN: 978-958-738-609-7 (rústica)

ISBN: 978-958-738-610-3 (digital)

Schmitt, Carl, 1888 - 1985 - Crítica e interpretación / Violencia - Bahía Portete (Guajira, Colombia) / Indígenas Wayú - Condiciones sociales / Violencia política / Conflicto armado / / I. Título / II. Serie. 


\section{ENEMISTAD POLÍTICA Y DIFERENCIA SEXUAL EN LA MASACRE DE BAHÍA PORTETE}

Retos al concepto de lo político de Carl Schmitt

MARGARITA MARÍA MARTÍNEZ OSORIO 


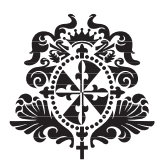

Colección Opera Prima

(C) Editorial Universidad del Rosario

(C) Universidad del Rosario,

Escuela de Ciencias Humanas

(C) Margarita María Martínez Osorio

Editorial Universidad del Rosario

Carrera $7 \mathrm{~N}^{\circ}$ 12B-41, oficina 501

Teléfono: 2970200 ext. 7753

http://editorial.urosario.edu.co
Primera edición: Bogotá D.C., mayo de 2015

ISBN: 978-958-738-609-7 (rústica)

ISBN: 978-958-738-610-3 (digital)

Coordinación editorial:

Editorial Universidad del Rosario

Corrección de estilo: Manuel Gómez

Diseño de cubierta y diagramación:

Kelly Johanna Narváez L.

Impresión: Xpress. Estudio gráfico y digital S.A.

Impreso y hecho en Colombia

Printed and made in Colombia

Fecha de evaluación: 30 de octubre del 2014

Fecha de aceptación: 27 de febrero del 2015

Todos los derechos reservados. Esta obra no puede ser reproducida sin el permiso previo por escrito de la Editorial Universidad del Rosario. 


\section{Contenido}

Agradecimientos ............................................................................. 9

Introducción............................................................................. 13

Guía de lectura .............................................................. 21

Capítulo I. El conflicto en bahía Portete:

la configuración de una enemistad política ............. 23

La tensión paramilitares-wayús y la teoría

del conflicto de Schmitt.................................... 24

Los paramilitares como enemigos de los wayús: la

amenaza a la forma de vida o existencia wayú 29

Enemigo verdadero y enemigo absoluto: el conflicto

de bahía Portete y la guerra de partisanos...... 44

Conclusiones: entre el teórico del conflicto y

el teórico reduccionista ..................................... 61

Capítulo II. El hermano wayú: irreductibilidad,

diferencia y desnaturalización .................................... 69

¿Quién es el enemigo paramilitar? La pureza

conceptual de Schmitt y los retos al

concepto de lo político...................................... $\quad 70$

La irreductibilidad y la guerra entre hermanos......... $\quad 79$ 
El hermano-enemigo wayú y la hostilidad

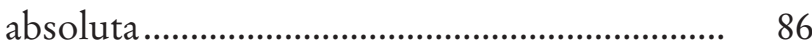

La desnaturalización del hermano ............................... 101

Conclusiones: el concepto de hermano-enemigo y sus potencialidades para pensar el conflicto en bahía Portete

Capítulo III. Hermanos y hermanas wayús:

la diferencia sexual y el concepto de lo político...... 117

Las mujeres wayús: enemigas de los paramilitares ... 119

La diferencia sexual: retos al concepto de

lo político y caracterización de la

enemistad de bahía Portete

El "punto de vista feminista" y la diferencia sexual:

la experiencia de género y las nuevas miradas al conflicto

La violencia sexual en contra de las mujeres wayús:

el significado social de los cuerpos y el

reconocimiento de las enemigas wayús

Conclusiones: ver el conflicto de bahía Portete

desde la violencia sexual................................... 165

Conclusiones. La hermana y lo político............................. 169

Bibliografía 


\section{Agradecimientos}

Quisiera aprovechar este espacio para contar brevemente la historia detrás de quien escribe esta tesis: a mitad de mi carrera había tomado la decisión de no seguir estudiando filosofía, porque sentía que las preocupaciones que, en un inicio, me habían motivado a escoger el camino de la academia y de la filosofía como proyecto de vida no estaban siendo satisfechas. Sentía que la discusión filosófica se enfrascaba en asuntos meramente conceptuales cuya relevancia para estudiar los problemas de violencia, de conflicto armado y de desigualdades sociales no era muy clara. En ese momento, llegué a pensar que me había equivocado de carrera, pues mis intereses por estudiar y analizar el conflicto colombiano y las injusticias que diariamente se derivan de él no se reflejaban en lo que estaba leyendo cada semana para mis clases.

Justo en el momento en que ya había tomado la decisión de abandonar filosofía y pasarme a estudiar historia, Beira Aguilar (mi tutora) e Iván Mahecha me comentaron que en el semestre 2010-II iban a dictar una clase sobre filosofía política feminista; siempre me han interesado las cuestiones relacionadas con el género y por eso me animé a tomar el curso, con muchas expectativas sobre lo que podría aportarme, no sólo en relación con los conocimientos teóricos 
que iba adquirir en ella, sino -y sobre todo-frente a la crisis profesional por la que estaba pasando. En efecto, esa clase me devolvió al mundo de la filosofía y de allí surgen las preocupaciones consignadas en esta tesis. El trabajo que Beira e Iván asignaron para mitad de semestre consistía en analizar la masacre de bahía Portete a la luz de las herramientas proporcionadas por las teóricas feministas que habíamos estudiado en clase. Desde ese momento comenzó mi compromiso con el caso de los wayús y con una filosofía política vinculada con los conflictos y las violencias vividas por los actores sociales reales. Esta tesis es, entonces, la síntesis de un proceso largo de dudas, incertidumbres y búsquedas: al escribirla iba encontrándome nuevamente con el tipo de preocupaciones e inquietudes que me impulsaron a elegir a la filosofía como carrera profesional y pude entender lo que, en un momento, me condujo a querer desistir.

Escribir esta monografía me llevó a enfrentarme conmigo misma, con mis dudas y mis incertidumbres respecto a lo que la filosofía podía proporcionarme y, aunque fue un proceso muy personal y solitario en muchas ocasiones, siempre tuve a mi lado a personas que fueron mi polo a tierra y a las que les agradezco infinitamente por acompañarme en la consolidación de este proyecto de tesis tan importante para mí. En principio, las palabras se quedan cortas para darle las gracias a Beira, una persona que, más que mi tutora, fue mi guía y mi amiga incondicional. Sus comentarios, sus palabras de ánimo, la confianza que depositó en mí y el hecho de que estuviera a mi lado a pesar de la distancia entre países, son cosas que siempre van a estar en mí y que marcaron profundamente 
mi carrera profesional. De igual manera, quisiera agradecer a Wilson Herrera por escucharme cada vez que lo necesité, por leerme y por hacerme comentarios muy pertinentes frente a lo que quería desarrollar en mi tesis. También le debo mi gratitud a Carlos Patarroyo por acompañarme durante el proceso de realización del proyecto; sus sugerencias, críticas y comentarios enriquecieron mis planteamientos y me llamaron la atención sobre cuestiones importantes de las que no me había percatado. Y a Adolfo Chaparro quiero darle las gracias por sugerirme a Derrida como una buena forma para plantear y desarrollar el problema de la diferencia sexual.

Por otra parte, esta tesis no hubiera funcionado sin el apoyo incondicional de mi mamá, sin sus palabras de ánimo constantes y sin la confianza que durante todo el tiempo puso en mí y en mis ideas. Gracias también a mi tía Gloria por transmitirme fortaleza y mostrarme que vale la pena levantarse cada día para luchar por las causas personales. A Sebastián Hernández, por escuchar mis largos discursos sobre filosofía, historia y feminismo durante horas, por recordarme constantemente que esto valía la pena y por haber sido mi fiel guerrero en las batallas que emprendí en las primeras etapas de este proceso. Agradezco también la compañía de Manuela y Juan Pablo, su apoyo y su interés por mis opiniones. A Camila, a Natalia, a Juan y a Sebastián Pérez les doy las gracias por ser mis amigos durante el tiempo de universidad y por estar dispuestos a apoyarme y a escucharme cuando más lo necesitaba. Finalmente, a Andrea, Laura, Mafe, Rocío y Carvi les debo todo mi aprecio por siempre estar ahí para mí, por estar a mi lado en los 


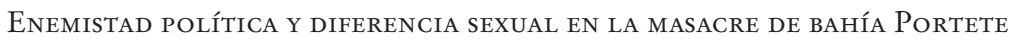

momentos difíciles y por darme fuerza para seguir adelante con mi tesis y con mi camino profesional. 


\section{Introducción}

En la mañana del 18 de abril de 2004 un grupo de aproximadamente 50 paramilitares del Frente Contrainsurgencia Wayuu, comandados por alias 'Pablo', algunos wayús del lugar e individuos que portaban uniformes del ejército irrumpieron en la región de bahía Portete en la Guajira colombiana con el objetivo de torturar y asesinar a las lideresas y líderes de la comunidad wayú que habitaba la zona. Con lista en mano y con la guía proporcionada por los wayús que los acompañaban, estos actores armados dejaron como saldo cuatro mujeres muertas (Margoth, Rosa, Diana y Reina), un hombre (Rubén Epinayú) y los restos incinerados de una persona cuyo sexo no se pudo determinar. No satisfechos con matar, mutilar y violar, los paramilitares también destruyeron el cementerio wayú, sacaron a los muertos de sus tumbas y ubicaron los restos de los individuos masacrados en distintos lugares considerados emblemáticos para la vida en comunidad del grupo indígena atacado. 
En el informe de la masacre elaborado por Memoria Histórica ${ }^{1}$ se registra lo sucedido en bahía Portete y se afirma que el accionar paramilitar responde a la pretensión por controlar los recursos económicos de la Alta Guajira. El puerto de bahía Portete "[...] ha sido entrada y salida de mercancía de contrabando" (Colombia, Centro Nacional de Memoria Histórica 2010, 43) desde el periodo colonial y eso resultaba atractivo para un grupo armado cuya actividad se definía, entre otras cosas, por los negocios ilegales del narcotráfico y el intercambio de armas y municiones. Entonces, el puerto de bahía Portete se mostraba ante los paramilitares como un escenario provechoso para comerciar drogas y armas y para, además, recibir ganancias adicionales al obtener el monopolio sobre las actividades comerciales que los wayús habían llevado a cabo por años y que les proporcionaban amplios beneficios monetarios. Así las cosas, y en vista de que los wayús se opusieron a la incursión paramilitar en la región y a su intención de monopolizar las actividades comerciales históricamente manejadas por este grupo indígena, los actores armados decidieron llevar a cabo la masacre, con el fin de intimidar a los wayús para que

1 El centro de Memoria Histórica es una entidad pública de nivel nacional que tiene como fin "reunir y recuperar todo el material documental, testimonios orales y por cualquier otro medio relativos a las violaciones de que trata el artículo 147 de la Ley de Víctimas y restitución de Tierras" (Colombia, Centro de Memoria Histórica, s. f.). Las funciones de Memoria Histórica se integran en el marco de la reparación y el derecho a la verdad que tienen las víctimas del conflicto armado colombiano, y como parte de esto, también se sostienen sobre el principio de que la ciudadanía en general puede consultar y disponer de la información relacionada con la violencia, el conflicto y la historia de su país. 
renunciaran a su lucha por el puerto. Y, en efecto, después de las muertes y las torturas, la comunidad wayú dejó bahía Portete por miedo a otra arremetida paramilitar. Alias 'Pablo' y sus compañeros cumplieron su cometido: obtuvieron el control sobre el territorio de los wayús.

Uno de los elementos centrales para entender el conflicto de bahía Portete y la ruptura que generó en la comunidad es el hecho de que Chema Bala, un indígena wayú, se alió con los paramilitares para efectuar la masacre en contra de su propio pueblo. Según lo registrado en el informe de Memoria Histórica, la disputa por el monopolio de las actividades del puerto no era algo nuevo para los wayú; por el contrario, era un conflicto que se venía gestando mucho antes de la incursión paramilitar y en el que estaban involucradas diversas familias indígenas que reclamaban su derecho a la propiedad del puerto. Una de esas familias era la de Chema Bala. La tensión entre los diferentes clanes wayús alrededor de la posesión de las actividades comerciales de la zona fue aprovechada por los paramilitares: al llegar a bahía Portete y conocer las particularidades de la disputa por el puerto, este grupo armado comenzó a generar alianzas con las familias enfrentadas para, de esta manera, ir adquiriendo poder al involucrarse directamente en el conflicto. En este contexto, la alianza que tuvo mayor peso y fue decisiva en el momento de la masacre fue la entablada con Chema Bala: este indígena, junto con sus hermanas, participaron en la planeación y ejecución de la masacre, indicándoles a los paramilitares a quién debían matar y cómo debían hacerlo, con el fin de generar mayor impacto en la comunidad y, así, poder dominar el tan 
codiciado puerto comercial. Las víctimas de la masacre se refieren a esta alianza y a sus nefastas consecuencias como una "herida en lo más profundo de su ser" (Colombia, Centro Nacional de Memoria Histórica 2010, 208).

¿Qué pasó ese 18 de abril de 2004 en bahía Portete? ¿Cómo entender las lógicas que llevaron a tales actos de violencia y sevicia en contra de los wayús? ¿Qué puede decir la filosofía al respecto? El filósofo francés Jacques Derrida afirma que en el mundo contemporáneo, en el que nuevas guerras, nuevos conflictos y nuevas violencias están haciendo presencia en diferentes contextos y de diversas maneras, la filosofía debe recurrir a estrategias que puedan responder a la "urgencia política e histórica" (Derrida 1998b, 97) de los nuevos tiempos. "No es ya tiempo de tomar su tiempo", dice Derrida, "nos sentimos, pues, es verdad, llamados 'en directo' a respuestas o responsabilidades inmediatas" (Derrida 1998b, 97), añade. Para Derrida, la filosofía política debe poner en suspenso el intento por articular sistemas conceptuales puros, completamente armónicos en su interior, para dar paso a una filosofía que responda a los tiempos de urgencia y que sea útil para pensar y problematizar lo que está pasando en el mundo político con los actores reales de las comunidades concretas. Es tiempo de atender el llamado de urgencia y pensar el mundo contemporáneo con las herramientas de la filosofía: desde esta perspectiva, es deber del filósofo político tomar los marcos teóricos y ponerlos a dialogar con la realidad política, tomarlos como herramientas de análisis susceptibles de ser puestas a prueba y repensadas, y no como reliquias que hay que conservar 
intactas y aisladas de cualquier tipo de influencia que las pueda impactar.

Derrida apunta, entonces, a pensar en los conceptos de la filosofía política como instrumentos para darle un lenguaje a las violencias contemporáneas, y a partir de allí, comenzar a problematizarlas y a pensar en caminos que puedan conducir a su resolución. En este proceso, los conceptos pueden sufrir cambios, replantearse o mostrarse como inútiles a la hora de leer los fenómenos; esto es inevitable: la realidad siempre le recordará al filósofo "[...] la irreductibilidad de aquello que se mantiene más allá [del] discurso mismo [...]” (Derrida 1998b, 100), es decir, la imposibilidad de capturar de manera absoluta todas las lógicas que se mueven en lo político. Pero de eso se trata: de poner a dialogar a los conceptos con la realidad; esto involucra, por un lado, recurrir a los conceptos como herramientas para entender los conflictos contemporáneos, y por el otro, examinar cómo dichos conflictos les imponen retos a los conceptos y los obligan a repensarse para que sean más adecuados en relación con la realidad a la que intentan atender. Este proceso es el que puede caracterizarse alrededor de la expresión acuñada por Ángela Uribe, "filosofía en tiempos de penuria"2 (Uribe Botero 2005, 23): una filosofía que pone sus herramientas a disposición de la comprensión de casos concretos vividos por actores sociales puntuales y que está dispuesta a repensarse

2 Esta expresión hace eco del planteamiento de Hannah Arendt según el cual somos "hombres en tiempos de oscuridad" (Arendt 1990). 
constantemente, con el fin de ser útil a la hora de atender a las demandas y exigencias de cada conflicto.

Así las cosas, presento un caso: la masacre de bahía Portete en contra del pueblo wayú. Y he seleccionado un marco teórico que puede proporcionar herramientas provechosas en el momento de dar cuenta de ciertas lógicas de guerra y de conflicto que parecen estar presentes en ese conflicto concreto: la teoría de lo político de Carl Schmitt. Este texto tiene, entonces, dos objetivos generales: en primer lugar, examinar las potencialidades y limitaciones del concepto de lo político de Schmitt a la hora de entender las particularidades del caso de bahía Portete; y, en segundo lugar, señalar que las reflexiones de Derrida con respecto a lo político, junto con la metodología del punto de vista feminista, pueden ser puntos de partida provechosos para futuras investigaciones que se propongan cubrir las limitaciones del concepto de lo político de Schmitt.

Tomo prestadas las palabras de Uribe para formular lo que pretendo hacer con los marcos teóricos sugeridos: "dado que la filosofía comporta una dimensión dialógica que le es esencial, mi invitación será [...] a escuchar aquello que algunos autores tendrían para decir sobre el caso que presento; a permitir que de lo dicho por cada uno de ellos quede algo que abra caminos para reflexionar acerca de la compleja situación que él devela" (Uribe Botero 2005, 25 26). Schmitt, Derrida y las teóricas del punto de vista feminista dialogarán sobre el caso de bahía Portete; cada uno de estos marcos conceptuales tendrá herramientas que aportar para explicar qué pasó ese 18 de abril en la Alta Guajira y 
a partir de ese diálogo se generarán preguntas y problemas que complejizan la lectura del caso y que permiten advertir las diferentes lógicas y violencias que subyacen a él.

Por una parte, el concepto de lo político de Schmitt permite caracterizar lo sucedido en bahía Portete como un conflicto político, en el que se puso en juego la existencia de la forma de vida wayú. En este sentido, con base en la teoría de Schmitt se puede examinar el antagonismo que se generó entre los paramilitares y el pueblo wayú, se puede dar cuenta de lo que estaba en juego en dicho conflicto y de la manera como todo eso condujo a unas lógicas de guerra y violencia como las que se revelaron el día de la masacre. Para Derrida, aunque la teoría de Schmitt provee muchos elementos útiles para acercarse a los conflictos y las violencias contemporáneas, el concepto de lo político debe ampliarse e introducir la noción de guerra interna o guerra entre hermanos como parte de sus lógicas, con miras a que se puedan explicar las disputas que surgen al interior de una comunidad política; siguiendo a Derrida, las guerras que se desarrollan desde el antagonismo entre los hermanos de la misma comunidad suponen una escalada de violencia y una agudización de la hostilidad. En relación con el caso de bahía Portete, la sugerencia de Derrida de introducir la noción de "guerra entre hermanos" resulta pertinente, en tanto que posibilita pensar en la figura de Chema Bala como un elemento de relevancia en el desarrollo del conflicto por el puerto, y más aún, como una coyuntura que agudizó la disputa y conllevó al uso de la violencia extrema. Las reflexiones de Derrida contribuyen, entonces, a complejizar la lectura 
del caso a la luz del análisis de la guerra al interior de la comunidad wayú: la disputa no sólo se llevó a cabo entre los paramilitares y los wayús, sino entre los mismos hermanos wayús, y estos son matices que se deben considerar en una lectura del caso que pretenda darle un lenguaje al conflicto y a la violencia que se gestó allí.

Por otra parte, el caso presenta otra particularidad que no parece fácil de capturar con las herramientas proporcionadas por Schmitt y, aunque es sugerida por Derrida, se requiere un lenguaje que la dote de sentido y muestre la pertinencia de señalarla en el marco del concepto de lo político: tanto mujeres como hombres wayús se presentaron ante los paramilitares como sus enemigas y enemigos directos en la disputa por el puerto. Pero en el momento de atacarlos, los paramilitares establecieron una diferencia: mientras las mujeres wayús fueron intimidadas y vulneradas sexualmente, las violencias ejercidas sobre los hombres no estuvieron atravesadas por lo sexual. ¿Por qué esa diferencia en los métodos de intimidación? Y ¿por qué sería pertinente señalarla en una lectura del caso construída alrededor del concepto de lo político?

Esta monografía apunta a plantear estas preguntas en el marco de la teoría política de Schmitt y a sugerirlas como caminos investigativos futuros que pueden proporcionar herramientas para capturar la complejidad de los conflictos y el modo como el género interviene en ellos como un elemento determinante en su definición. Derrida, en Políticas de la amistad, sugiere que la conceptualización schmittiana debería tomar en consideración una noción que capturara 
la importancia de pensar en lo político desde la diferencia sexual y propone la construcción de un nuevo concepto que dé cuenta de ello, a saber: el de hermana. En este contexto, mi propósito es indagar por la pertinencia de una noción como la de hermana para dar cuenta de la diferencia sexual en el conflicto de bahía Portete y sugerir estas reflexiones como centrales para la articulación de investigaciones futuras. La metodología del punto de vista feminista y su aplicación por parte del feminismo radical de Catharine Mackinnon proveen herramientas que posibilitan el planteamiento de esos problemas y que dejan abiertos nuevos horizontes para pensar los conflictos políticos. Por eso, la conclusión de este texto, en lugar de ser un cierre, es una apertura que sugiere posibilidades para pensar en lo político desde otras ópticas $\mathrm{y}$ otros lenguajes que puedan responder a realidades antes no consideradas y que parecen ser cruciales en el desarrollo de los conflictos humanos concretos.

\section{Guía de lectura}

La monografía está compuesta de tres capítulos. El primero de ellos tiene por objetivo realizar un ejercicio de aplicación de conceptos: lo que se pretende en esta parte es examinar las potencialidades de la teoría de Carl Schmitt para dar cuenta de la disputa de bahía Portete. En virtud de esto, a partir del lenguaje schmittiano se caracterizará al conflicto wayú-paramilitares como el producto de una enemistad política y se mostrarán las consecuencias que se derivan de denominarlo de esa manera. El segundo capítulo recoge las reflexiones de Derrida alrededor del concepto de 
lo político de Schmitt, con el fin de poner de manifiesto la complejidad del caso. Se introducirá la noción de "guerra entre hermanos" y, con ello, se mostrará que el antagonismo al interior de la misma comunidad wayú generó las lógicas de guerra y violencia absolutas que se efectuaron en la masacre. Por último, el tercer capítulo tiene por objetivo plantear vías investigativas futuras que posibiliten la introducción de la diferencia sexual como un elemento relevante a la hora de pensar en lo político y en el modo en que este concepto da cuenta del caso de bahía Portete. 


\section{Capítulo I El conflicto en bahía Portete: la configuración de una enemistad política}

El presente capítulo tiene por objetivo utilizar las herramientas proporcionadas por el concepto de lo político de Schmitt para entender lo sucedido en bahía Portete. Esta primera parte está pensada como un ejercicio de aplicación de conceptos: ${ }^{3}$ lo que se pretende es dar cuenta de ciertas lógicas de guerra y enemistad que parecen estar presentes en el caso a partir de las reflexiones sobre el conflicto articuladas por Schmitt. Así las cosas, se argumentará a favor de la idea según la cual la disputa entre paramilitares y wayús fue un conflicto político en el que la existencia de la comunidad indígena se vio amenazada directamente por un enemigo externo y en el que el carácter de la enemistad fue absoluto, lo cual implicó el uso de violencia extrema con el fin de eliminar al enemigo. En la última sección de este capítulo, se esbozarán ciertas

3 Este texto parte de un supuesto: la filosofía política “[...] puede y debe jugar un rol en el debate público” [traducción propia] (Applied Philosophy s. f.). Así, las teorías de la filosofía política deben disponer de sus conceptos para explicar, entender y dar cuenta de las situaciones políticas del mundo contemporáneo. En este sentido, cuando digo que realizaré un ejercicio de "aplicación de conceptos" me refiero a que mostraré las potencialidades y limitaciones de la teoría de Schmitt en el momento de entender ciertas lógicas que se gestaron en el conflicto de bahía Portete. 
limitaciones de la teoría de Schmitt a la hora de acercarse a lo acaecido en bahía Portete y, con ello, se introducirán las reflexiones a seguir en los capítulos subsiguientes.

\section{La tensión paramilitares-wayús y la teoría del conflicto de Schmitt}

Schmitt es un pensador del conflicto. Tal y como lo afirma Chantal Mouffe, en la tradición de la filosofía política "algunos teóricos como Hannah Arendt perciben lo político como un espacio de libertad y deliberación pública, mientras que otros lo consideran como un espacio de poder, conflicto y antagonismo" (Mouffe 2009, 16). El pensamiento de Schmitt se ubica en esa segunda perspectiva, de acuerdo con la cual el conflicto es una dimensión insuperable de la existencia humana y cualquier intento por conceptualizar la manera como se constituyen y organizan las sociedades pasa inevitablemente por el antagonismo inherente a todas las relaciones sociales. En este sentido, una teoría que tome al conflicto como el eje de reflexión parte del reconocimiento de que el carácter de las relaciones entre grupos humanos es tal que el poder es un elemento constitutivo, definitorio e insuperable de la vida en sociedad (Mouffe 2003b, 112); prescindir de él supondría ignorar el desenvolvimiento de la historia humana o, en términos de Schmitt, sería negar lo que es, lo que realmente sucede cuando de relaciones humanas se trata. Obviar la dimensión conflictiva inherente a la condición de los seres humanos equivaldría a adoptar una actitud ingenua ante la realidad y, siguiendo a Schmitt, por más teorías normativas que dictaminen el "deber ser", es indudable que en 
el plano de lo fáctico, la guerra, la hostilidad, el antagonismo y el poder son elementos constantes y determinantes en el desarrollo del mundo humano (Schmitt 1939, 179).

¿Por qué escoger una postura agonística-como la llamaría Mouffe- para acercarse a la masacre de bahía Portete? En principio, se puede decir que la masacre fue la expresión más contundente y violenta de un conflicto entre dos actores: los wayús y los paramilitares. Allí se pusieron en juego lógicas que amenazaban directamente la existencia de la comunidad wayú y que la enfrentaban con un actor que contradecía drásticamente sus valores, principios y formas de vida. En el informe elaborado por Memoria Histórica se resalta este hecho: "mientras que para los wayuu la importancia del territorio radica en que da sentido al orden social garantizando la sobrevivencia y herencia cultural y comunitaria, para los paramilitares el territorio es un escenario móvil para la guerra y el usufructo en procura de intereses económicos" (Colombia, Centro Nacional de Memoria Histórica 2010, 21-22). De acuerdo con lo señalado en la cita, una de las diferencias centrales entre los wayús y los paramilitares radica en la forma como conciben el territorio. Así, por un lado, el territorio de bahía Portete era codiciado por los paramilitares en virtud de su potencial comercial al tener un puerto marítimo caracterizado por ser un centro de contrabando desde la época colonial. Para los paramilitares, adquirir el monopolio de las actividades del puerto suponía, además de obtener el control sobre el intercambio ilegal de productos llevado a cabo por los wayús desde el periodo colonial, usar los circuitos comerciales abiertos por los wayús para sus propios fines 
vinculados con el narcotráfico (Colombia, Centro Nacional de Memoria Histórica 2010, 24). Pero, por otro lado, el valor que el territorio tiene para la comunidad wayú rebasa los intereses económicos o comerciales y, más bien, se postula como un referente cultural de vital importancia en su vida en comunidad. Como bien lo advierte Victoria, una wayú entrevistada por la politóloga María Ochoa Sierra, para los wayús el territorio guarda sus prácticas y su historia:

el territorio para el pueblo indígena no es el pedazo de tierra donde vive. Es todo, territorio es todo [...] la relación con el territorio es integral. No lo vemos de una forma de propiedad privada como lo ven ustedes los no indígenas [...] El pueblo wayú y otros necesitan el territorio para seguir existiendo como pueblos, para mantener nuestras tradiciones, para poder ejercer nuestro gobierno [...] (Ochoa Sierra 2011, 82)

De ahí que se pueda hablar de conflicto: la lógica paramilitar de conquista territorial para provecho económico choca con la valoración del territorio como referente cultural, pues el arraigo territorial de los wayús les impedía a los paramilitares gozar de un monopolio total sobre bahía Portete. En otras palabras, en vista de que el significado del territorio en la comunidad wayú no se reduce a sus potencialidades económicas o comerciales, sino que involucra prácticas, creencias y significados que competen directamente a lo que se considera valioso en la constitución de la comunidad wayú, abandonar el territorio al dejarlo en potestad 
paramiliar implicaba renunciar a un elemento central en su modo de vida y en la configuración de su identidad o de lo que significa "ser wayú". El interés económico paramilitar entra en conflicto con el interés por mantener la existencia de la comunidad wayú en su territorio ancestral. Y aunque, en un comienzo, algunos wayús generaron alianzas con paramilitares, con el fin de obtener protección frente a disputas intrafamiliares que se estaban gestando alrededor del puerto, el conflicto paramilitares-wayús se aguzó en el momento en que los primeros explicitaron su deseo por el dominio territorial total de bahía Portete, lo cual implicaba la pérdida de la soberanía del pueblo wayú sobre el territorio que ancestralmente le había pertenecido y a partir del cual articulaba su modo de vida, sus costumbres y sus creencias. En esta última etapa, el conflicto adquirió el carácter de un juego de suma cero: o los paramilitares expulsaban a los wayús del territorio o viceversa, pero no había posibilidad alguna de convivencia o conciliación entre las dos lógicas enfrentadas.

Una teoría política que ubique al conflicto en el centro de la reflexión sobre la organización y configuración de las sociedades humanas tendría mucho que decir frente al caso de bahía Portete. Se trata de una situación concreta en la que se pueden advertir dos actores luchando por la defensa de su concepción territorial y en la que la hostilidad, la posibilidad de la guerra y el poder se ponen de presente. Pero además de la dimensión conflictiva de este caso, a los teóricos agonísticos, y en particular a Schmitt, les resultaría atractiva la posibilidad de estudiar la masacre de bahía Portete, en la medida en que es en lo fáctico o en el examen de situaciones 
reales que la noción de conflicto y el concepto de lo político derivado de ella adquieren sentido. ${ }^{4}$ Hasso Hofmann ha dicho que "Schmitt domina como ningún otro teórico del Estado el arte de conceptualizar situaciones, conflictos y desarrollos" (citado por Corbetta, 2002, 237), y es que, en efecto, el concepto de lo político schmittiano no proporciona una definición exhaustiva o de contenido sobre lo que significa que una situación sea política; por el contrario, Schmitt establece un criterio para identificar un conflicto político que es susceptible de ponerse a prueba o dotarse de contenido en las situaciones puntuales vividas por grupos humanos particulares. Siguiendo a Montserrat Herrero López, "la inspiración de los escritos de Schmitt es siempre la historia concreta" (Herrero López 1997, 233). Es en el examen de lo que es, de las diversas maneras de existir de las comunidades humanas, donde lo político y el conflicto se dotan de contenido y obtienen su significado concreto. Entonces, hay

4 A lo largo del presente texto se advertirá una tensión entre dos supuestos de la teoría de Schmitt: por un lado, se encuentra la idea según la cual lo político se restringe al marco de los Estados entendidos como unidades políticas consolidadas y reconocidas como tal. Desde esta perspectiva, todo conflicto que no se ajuste a estos límites, no es propiamente político. Por otro lado, Schmitt también defiende que el mundo político es un pluriverso, en tanto que existen diversas formas de vida que entran en conflicto unas con otras con el fin de mantener su existencia. Así, teóricos como Mouffe y Derrida señalan que en este "segundo Schmitt” hay una preocupación por entender los conflictos políticos reales; independientemente de si se restringen o no al marco de los Estados, la noción de pluriverso abre la posibilidad de examinar los conflictos, enemistades y antagonismos que se presentan constantemente en diversos contextos. Siguiendo el espíritu del "segundo Schmitt", este capítulo se propone estudiar un conflicto no desarrollado en el marco de Estados soberanos a partir de las herramientas conceptuales de la teoría del conflicto de Schmitt. 
que preguntarse: ¿cómo puede entablarse el vínculo entre la masacre de bahía Portete y la teoría del conflicto de Schmitt? ¿Cómo entender la disputa paramilitares-wayús desde el lenguaje de lo político asentado sobre el conflicto?

\section{Los paramilitares como enemigos de los wayús: la amenaza a la forma de vida o existencia wayú ${ }^{5}$}

Schmitt comienza su argumentación en El concepto de lo político con la siguiente aseveración: “en general, 'político' es asimilado, de una y otra manera, a 'estatal' o al menos es referido al Estado. Entonces el Estado aparece como algo político, pero lo político se presenta como algo estatal: se trata, manifiestamente, de un círculo vicioso" (Schmitt 1939, 171-172). Con el objetivo de evitar este círculo vicioso generado a partir de la equiparación entre lo político y lo estatal, Schmitt establece una definición de lo político que revela las lógicas propiamente políticas, independientemente de la relación que se pueda establecer entre ellas y el Estado. Así, el punto de partida para iniciar dicha labor es la identificación de categorías que remitan estrictamente a lo político, esto es, que sean autónomas frente a otros ámbitos como el moral, el estético o el económico. Según Schmitt, de la misma manera como puede decirse de lo moral que sus categorías propias son "bueno y malo" y de lo estético que son "bello y feo",

5 En esta sección, me concentraré en definir a los paramilitares como los enemigos externos de los wayús. Sin embargo, no hay que perder de vista el hecho de que algunos miembros de la comunidad wayú se aliaron con ese enemigo extranjero para acabar con su propia comunidad. Esto será analizado con mayor énfasis en el segundo capítulo. 
debe poder encontrarse una distinción propiamente política que para él sería: “[...] la distinción de amigo y enemigo. Ella ofrece una definición conceptual, es decir, un criterio, no una definición exhaustiva o una explicación de contenido" (Schmitt 1939, 177). ${ }^{6}$

Como bien lo indica Enrique Serrano, este criterio “amigo-enemigo” propuesto por Schmitt debe cumplir dos condiciones para adquirir su carácter político: en primer lugar, la intensidad del antagonismo amigo-enemigo debe ser tal que la posibilidad de la guerra esté siempre presente; $y$, en segundo lugar, el enemigo debe ser público (Serrano 2002, 23). Con respecto a lo primero, Schmitt afirma que el criterio "amigo-enemigo" indica "[...] el extremo grado de intensidad de una unión o de una separación, de una asociación o de una disociación [...]" (Schmitt 1939, 177). El enemigo es definido por Schmitt como "el otro" cuya forma de vida amenaza la forma de existir propia. La determinación de quién es amigo y quién es enemigo estará condicionada por esa decisión de quién es "el otro" y, por supuesto, de quién puede ser un aliado en el proceso de defender la propia existencia. La lucha o el enfrentamiento "cuerpo a cuerpo" entre enemigos es siempre, para Schmitt, un presupuesto de esa identificación del otro y de la tensión que este introduce al amenazar la existencia de su enemigo; sin embargo, que sea un presupuesto no significa necesariamente que todo

6 Tal y como lo señala Wilson Herrera, Schmitt “[...] introduce esta distinción sin explicar su origen, como si fuera evidente por sí misma [traducción propia]" (Herrera 2008, 100). 
antagonismo deba ser llevado a las armas. Lo que es importante para Schmitt es el hecho de que, como parte del grado de intensidad de la tensión y de que esta es una cuestión que pone en juego la existencia propia, la guerra siempre debe ser una posibilidad; el grado de intensidad de la unión o separación de amigos y enemigos se mide, entonces, por la posibilidad inmediata o lejana de llevar el antagonismo a las armas: si la guerra se presenta como altamente plausible en una situación determinada, la hostilidad amigo-enemigo es muy intensa y no hay lugar para negociación o conciliación, y al contrario, si la guerra es una posibilidad lejana, la tensión entre amigos y enemigos está presente, pero no tiene un alto grado de intensidad y la conciliación es una vía probable. Por otro lado, de acuerdo con Schmitt, el enemigo político es hostis y no inimicus (Schmitt 1939, 179); no se trata de un enemigo privado que responde a odios personales (inmicus), sino de un enemigo público (bostis): el enemigo político es un pueblo o unidad política que amenaza la existencia de otro pueblo o unidad politica. ${ }^{7}$

De esta caracterización inicial del concepto de lo político de Schmitt se puede hacer un primer acercamiento al caso. Siguiendo de cerca el lenguaje schmittiano, habría que

7 Vale la pena resaltar el hecho de que Schmitt “[...] da una prioridad a la figura del 'enemigo' y se hace a un lado el tema sobre cómo es posible que los 'amigos' constituyan una esfera pública, que hace posible que el 'extraño' el 'otro' o incluso el transgresor interno del orden público (el que deja de ser 'amigo') se convierta en 'enemigo político'” (Serrano 2002, 23). Esto será clave en el momento de problematizar la noción de enemigo a la luz del concepto de hermano o enemigo interno propuesto por Derrida. 
identificar y caracterizar a los enemigos o a las partes enfrentadas por el dominio del territorio de Bahía Portete: de un lado, se encuentra el pueblo wayuu ${ }^{8}$. De acuerdo con Ochoa Sierra, los wayuu "se conciben a sí mismos como un grupo social autónomo, denominan a La Guajira Tou Main, que significa 'mi tierra' y pude corroborar cómo algunos hablan de mi patria wayú, o [...] su woumainoa'a lo que significa 'patria guajira'” (Ochoa Sierra 2011,13). En efecto, después de la masacre, las víctimas alegan que su autonomía fue vulnerada, y con esto se refieren a lo que desde la Constitución de 1991 se reconoció como las demandas básicas de todo pueblo indígena que formara parte de Colombia, a saber: territorio, cultura y autodeterminación (Desde el desierto 2007, 39). Pero además de los principios constitucionales, aunque en estrecha relación con ellos, expresiones como Tou Main o "mi patria wayú" indican que antes de ser ciudadanos colombianos o venezolanos, ${ }^{9}$ los wayús se identifican a sí mismos como un grupo autónomo, regido por sus propios códigos y prácticas. Esto no significa que el pueblo wayú se encuen-

8 Soy consciente de que referirme al "pueblo wayú" puede resultar problemático, en la medida en que la expresión denota una comunidad homogénea y pasa por alto las diferencias internas que efectivamente existen y tuvieron consecuencias importantes en el desarrollo del conflicto con los paramilitares. Sin embargo, por ahora, utilizaré la expresión, con la salvedad de que esta será problematizada a partir de las reflexiones de Derrida y de los planteamientos de los capítulos subsiguientes.

9 Aquí es importante advertir que "los wayús son una etnia de carácter binacional que habita tradicionalmente [...] en la península de La Guajira ubicada en el norte de Colombia en los municipios de Uribia, Manaure y Maicao, y [...] en el noreste de Venezuela en el distrito de Páez en el estado de Zulia" (Ochoa Sierra 2011, 9). 
tre totalmente desligado de la nación colombiana, pero su condición de autonomía cultural y territorial sí es un asunto que se ha presentado como no negociable, en la medida en que, para los wayús, allí está en juego “[...] la legitimidad para regirse y autogobernarse dentro de su jurisdicción en concordancia con sus propios valores culturales" (Guerra Curvelo 2002, 205). En este marco del fuerte reclamo por la autonomía y de la identificación de la "patria wayúu" se ubica la importante noción de alteridad que atraviesa la manera como los wayús se relacionan con otros grupos con los que conviven: para ellos, todos aquellos que no son wayús son arijunas $^{10}$, esto es, extranjeros, otros.

Esto último resulta particularmente llamativo cuando se lee desde el lenguaje de Schmitt. El antagonismo amigoenemigo que funciona como criterio para identificar una situación propiamente política puede descansar, como lo indica Mouffe, en la “[...] formación de un 'nosotros' como opuesto a un 'ellos', y se trata siempre de formas colectivas de identificación" (Mouffe 2009, 18). La noción de “arijuna" revela la distinción entre "nosotros" y "ellos", al demarcar quiénes son extranjeros o ajenos al pueblo wayú. Sin embargo, la oposición "nosotros-ellos" o, en este caso, “alijuna-wayú” no recaería -a la luz de la conceptualización schmittiana- inmediata ni necesariamente en el antagonismo "amigo-enemigo". En otras palabras, el hecho de que los wayús señalen a los no wayús como arijunas no implica

10 Ochoa Sierra (2011) utiliza la palabra "arijunas", el Centro Nacional de Memoria Histórica (2010) habla de "alijunas”. Utilizaré ambas indistintamente. 
necesariamente que esos otros sean enemigos per se; todo otro es potencialmente un enemigo, pero se necesita una condición básica para que se pase de la potencia al acto. Dicha condición es, en palabras de Schmitt, la amenaza y negación del modo de existencia propia (Schmitt 1939, 178), o en términos de Mouffe, el cuestionamiento a la identidad del "nosotros" (Mouffe 2009, 23). Así, en el momento en que esos otros se convierten en una amenaza directa al "nosotros" o a lo que se define como vital para una comunidad determinada, el otro se convierte en enemigo susceptible de ser enfrentado en una guerra. Puede que los valores, principios y forma de vida del otro sean incompatibles con lo propio, pero esta situación por sí misma no conlleva al agrupamiento político entre amigos y enemigos; para esto último se requiere que esa forma de vida del otro ponga en riesgo o amenace la mía. Y es dentro de este marco desde donde es posible catalogar a los paramilitares como enemigos de los wayús. Pero, ¿quiénes eran esos paramilitares que amenazaron a los wayús? ¿Quiénes eran los enemigos? ¿Cómo operaron? ¿Cuáles eran sus objetivos concretos?

La masacre de bahía Portete fue comandada por el paramilitar Arnulfo Sánchez, alias 'Pablo', perteneciente al Frente Contrainsurgencia Wayuu, y por Rodrigo Tovar Pupo, alias 'Jorge 40', jefe del Bloque Norte de las Auc. La planeación y ejecución de la masacre no son fenómenos aislados, responden a un proyecto de expansión paramilitar ejecutado en la región Caribe entre los años 1997 y 2005 (Colombia, Centro Nacional de Memoria Histórica 2011, 29). Bajo el liderazgo de Jorge 40 y Salvatore Mancuso, y después de la reunión 
convocada por los Castaño para entablar formalmente las alianzas entre narcotraficantes, fuerza pública, políticos y ganaderos del Caribe, el Bloque Norte de las Auc configura un proyecto de expansión y control de los departamentos del Atlántico, Magdalena, Cesar y la Guajira. Los fines sobre los que se sustentaba el plan de dominio paramilitar en el Caribe colombiano están inscritos en la llamada "tercera generación del paramilitarismo": "un paramilitarismo sin agenda política, pero con mucho dinero y capacidad de corrupción. El objetivo de esta variante paramilitar, como bien se ha dicho, no era ganarse políticamente a la población, sino 'controlar la población como parte del dominio territorial'” (Colombia, Centro Nacional de Memoria Histórica 2010, 25).

Sin embargo, a pesar de que se trata de un paramilitarismo que busca la expansión territorial vinculada con los beneficios económicos derivados de las actividades del narcotráfico y el contrabando, la actividad de los paramilitares del Bloque Norte de las auc en la Guajira no puede ser reducida a lo meramente económico. Como bien lo señala Mauricio Romero, los paramilitares son "empresarios de la coerción", es decir, son individuos especializados “[...] en administración, despliegue y uso de la violencia organizada” (Romero 2003, 17), con el objetivo de obtener ventajas económicas. Romero afirma que el manejo de violencia organizada supone la regulación de comportamientos y, con ello, la conformación de órdenes sociales precisos; en efecto, el poder de ejercer violencia sistemática descansa en nociones de autoridad, de control y de obediencia que repercuten en la conformación de órdenes y subjetividades producidas como parte de las 
relaciones de poder y de resistencia que se establecen entre el paramilitar y aquellos que son sometidos a él. La violencia es, en últimas, productora de prácticas y discursos (Romero $2003,59)$ que regulan comportamientos humanos y, en este sentido, es política. De ahí que, aunque los paramilitares enemigos de los wayús codiciaran el puerto de bahía Portete en virtud de los beneficios económicos que su posesión acarrearía, el uso de la violencia como arma sistemática para someter a los wayús es un elemento que rebasa los límites económicos y se ubica más en el plano de lo político.

Justamente, las estrategias llevadas a cabo por estos actores armados para la conquista del Caribe abarcan desde la inserción en los circuitos políticos de las regiones y la obtención del monopolio de las actividades comerciales, hasta la intimidación de las poblaciones y los líderes locales, las masacres, las desapariciones forzadas y las violaciones sexuales; no sin razón, las víctimas de la arremetida paramilitar nombran este momento de su historia como la "Ruta del Terror" (Colombia, Centro Nacional de Memoria Histórica 2011, 32-34). La masacre de bahía Portete se inscribe, entonces, en este proyecto de expansión paramilitar, tanto por los fines perseguidos (el control territorial y el monopolio sobre el comercio y las rutas de intercambio) como por los recursos utilizados para subordinar e intimidar a la comunidad wayú (tortura, violaciones sexuales, alianzas con individuos influyentes, entre otros). En últimas, el territorio como medio para la obtención de poder económico y el uso de la violencia organizada para llegar a tal fin es la lógica a la que se ciñe la actividad paramilitar en bahía Portete, y ese operar es lo que 
supondrá el surgimiento de la enemistad con los wayús, en la medida en que estos últimos vieron en la lógica de conquista paramilitar una amenaza para la existencia de su comunidad. En términos de Ochoa Sierra: "los wayús deciden tomar parte en la guerra cuando ésta empieza a ser suya, es decir, cuando los paramilitares los atacan y quieren disputarles el control de su propio territorio y de su autonomía en éste" (Ochoa Sierra 2011, 70). ${ }^{11}$

De esta manera, los arijunas-paramilitares se convierten en enemigos cuando su lógica de conquista territorial pone en peligro la autonomía del pueblo wayú. En ese momento surge aquello que Schmitt llamaría un conflicto político,

11 Es preciso señalar que históricamente los enemigos de los paramilitares han sido los grupos guerrilleros, y en particular, las farc (Salas 2008, 20-27). De hecho, Ángela Salas, en su recuento del surgimiento de los grupos paramilitares, afirma que, desde sus inicios, estos grupos se crearon con el fin de oponerse a la actividad guerrillera y a la manera como esta afectaba intereses de élites regionales o de ciertos grupos de poder. La enemistad paramilitares-wayús es producto de una coyuntura precisa en la que los intereses de estos dos grupos entraron en contradicción y se pusieron en juego cuestiones vitales para la comunidad wayú. Lo que resulta interesante del caso de bahía Portete en relación con la conceptualización schmittiana es que lo que para los wayús fue un conflicto en el que su existencia como comunidad se puso en cuestión, para los paramilitares fue un asunto de beneficios económicos en el que no se amenazaba su existencia como grupo. A pesar de que, del lado de los paramilitares, la disputa por el puerto no parezca política en el sentido en que no se amenazó su existencia como grupo, sí puede decirse que la oposición wayú a la actividad paramilitar sí fue política en tanto que los wayús cuestionaron los modos de operar paramilitar y se opusieron a ellos en defensa de la existencia de su comunidad; por otra parte, los paramilitares ratificaron su existencia al enfrentar a los wayús y a su posesión del territorio. La tensión entre ambas partes de la disputa se desarrolló alrededor de la defensa que cada una de ellas hacía frente a su propia forma de existencia, a sus lógicas y a sus modos de estar en el mundo. En esto radicaría lo propiamente político del conflicto por el puerto de bahía Portete. 
pues una comunidad que se declara autónoma, que tiene un territorio propio y unas prácticas y códigos internos, es amenazada por otro, por un extranjero. Aquí no se trata de una enemistad entre inmicus o enemigos guiados por causas personales, sino de una enemistad política, porque es una comunidad que le declara la guerra a otro amenazante con el fin de defender su forma de vida propia. De igual manera, la posibilidad de la guerra o de llevar la disputa al combate cuerpo a cuerpo fue una constante en el conflicto entre los wayús y los paramilitares; de hecho, más que una posibilidad, fue una realidad, tanto en la perpetración de la masacre como en los combates precedentes, por ejemplo, cuando los wayús mataron a varios paramilitares en una emboscada. Así, las dos condiciones del concepto de lo político de Schmitt parecen cumplirse en el caso de bahía Portete: por un lado, el grado de intensidad de la separación entre amigos y enemigos es tal que la posibilidad de la guerra está siempre presente y, de hecho, en este caso, efectivamente hubo combate cuerpo a cuerpo; y por otro lado, la enemistad es pública: se trata de una comunidad defendiendo su propia forma de vida frente a una amenaza extranjera.

La disputa en bahía Portete se muestra, en principio, como un terreno propicio para un examen del concepto de lo político en una situación histórica concreta, ya que el conflicto relativo a la defensa de la forma de vida propia está presente y esto corresponde con lo que Schmitt identificaba como relevante políticamente. Vicente Gonzalo Massot afirma que lo que primero se destaca de la obra de Schmitt es el hecho de que este pensador toma como eje de su análisis a la 
“dimensión agonal” de lo político: “es que Schmitt y Marx, cualesquiera resulten sus diferencias en otros aspectos de su pensamiento, coincidieron en su interpretación de lo político como una relación hostil. Para uno y otro, el fenómeno social predominante es el conflicto que, lejos de resultar una anomalía o una perversión, es intrínseco a lo político” (Massot 2002, 83). En efecto, para Schmitt, el criterio "amigo-enemigo" encuentra su fundamento en el antagonismo; si una disociación o una unión tienen tal intensidad para que "el otro" se convierta en el enemigo susceptible de ser enfrentado en una guerra y la defensa de la forma de vida propia conlleva el agrupamiento de unidades políticas, allí se trata de una situación propiamente política.

En relación con lo anterior, dice Schmitt que, a diferencia de otras conceptualizaciones de lo político -y, específicamente, en contraposición con el liberalismo ${ }^{12}-$, la suya toma como punto de partida una dimensión existencial y concreta (Schmitt 1939, 178). La relación antagónica entre unidades

12 Uno de los puntos más álgidos de la teoría de Schmitt es el referente a su crítica al liberalismo. De acuerdo con este pensador, "el liberalismo ha tratado de resolver, en un dilema para él típico de espíritu y economía, la figura del enemigo, refiriéndola a un competidor, desde el punto de vista comercial, y a un adversario de discusión, desde el punto de vista espiritual” (Schmitt 1939, 178-179). Esto tiene como consecuencia, siguiendo a Schmitt, la "despolitización de lo político", pues el enemigo no se define por ser propiamente político, sino que se subordina a lo económico o lo moral; lo político deja de ser aquello en lo que se pone en juego la propia existencia, para convertirse en un espacio en el que se discuten intereses económicos o principios morales. En últimas, para Schmitt, la dimensión antagónica y existencial de lo político se desvaneve con el liberalismo. Para una comprensión más precisa del argumento contra el liberalismo y de sus respectivas críticas y respuestas ver: Holmes (1999), Serrano (2002), Mouffe (2003a), Meier (2008) y el capítulo ocho de Schmitt (1939). 
políticas no es simbólica o discursiva; el enemigo político no es un adversario de palabra con quien se entablan discusiones o desacuerdos sólo al nivel del discurso. Por el contrario, el enemigo político es aquel con quien existe la posibilidad real de una guerra, esto es, aquel que concretamente amenaza la existencia misma de mi unidad política. Pero Schmitt es enfático en señalar que la guerra no agota la esencia del antagonismo político. Como bien lo advierte Stephen Holmes, "la guerra no es ni el objetivo principal ni el contenido de la política. Lo que hace de la política algo especial, lo que la dota de su 'específica tensión política', es la sombra de extinción personal que proyecta toda acción genuinamente política” (Holmes 1999, 36). En efecto, no es la guerra propiamente lo que hace de lo político una noción concreta y existencial, es la posibilidad misma de que la unidad política se extinga la que le da sentido al antagonismo y la que revela al enemigo político en cuanto tal.

Según Schmitt, "los conceptos de amigo, enemigo y lucha adquieren su significado real por el hecho de que se refieren de modo específico a la posibilidad real de la eliminación física. La guerra deriva de la hostilidad puesto que ésta es negación absoluta de todo otro ser. La guerra es sólo la realización extrema de la hostilidad" (Schmitt 1939, 182-183). Así, el concepto de enemigo que está en el centro de lo político no depende de si hay guerra o no, pero esta tiene que ser siempre una posibilidad. Y es que, para Schmitt, lo político puede distinguirse de la guerra en la medida en que esta última tiene sus propias lógicas, estrategias y objetivos, pero esa guerra adquiere un sentido específicamente político sólo si 
su presupuesto básico es el antagonismo amigo-enemigo. En esta dirección, la guerra es la expresión más contundente del antagonismo; es la que lo dota de la intensidad requerida para agrupar a las unidades políticas alrededor de la distinción entre amigo y enemigo. Lo propiamente político no es la guerra en sí misma, sino la manera como su posibilidad existencial o real revela el antagonismo articulado en un caso concreto en que una unidad política amenaza la forma de vida de la otra. Lo que está en juego es, en últimas, la propia existencia; es en virtud de esto que el antagonismo y la posibilidad de la guerra derivada de él se hacen plausibles. Puesto en términos de Schmitt, "si una destrucción física semejante de la vida humana [la guerra] no deriva de la afirmación existencial de la propia forma de existencia frente a una negación igualmente existencial de dicha forma, no puede tampoco encontrar legitimación” (Schmitt 1939, 196).

$\mathrm{Si}$, desde la teoría de Schmitt, la destrucción física de la vida humana debe ser una posibilidad siempre presente en un conflicto político, la masacre de bahía Portete es un caso en el que el arremetimiento contra la existencia no sólo física sino moral de los miembros de una comunidad no se quedó en el plano de lo posible, sino que fue un hecho. Los paramilitares afirmaron su propia forma de existencia y negaron totalmente la existencia wayú por medio de la intimidación física y la destrucción de elementos que se consideraban sagrados y vitales para la comunidad. Según Ochoa Sierra,

Los paramilitares degradaron los aspectos más sagrados en la cultura wayú, lo que hizo que sus golpes fueran 
contundentes y ejemplarizantes. Hubo desapariciones forzadas cuando el entierro para los wayús es necesario para el descanso de los muertos, profanaron sus cuerpos al sacarlos de las tumbas siendo que esto sólo es posible cuando se hace el segundo entierro y bajo ninguna otra circunstancia, violaron sexualmente sobre todo a mujeres, torturaron a hombres y mujeres, adultos y pequeños sin distinción de género y edad, destrozaron el lugar sagrado de los wayús, los cementerios, donde descansan sus ancestros, siendo los huesos de toda la línea genealógica el testimonio de la propiedad de la tierra. (Ochoa Sierra 2011, 58)

La tortura sexual, las mutilaciones, las desmembraciones y los asesinatos son expresiones de la violencia extrema efectuada por los paramilitares para acabar físicamente con las lideresas y líderes de la comunidad que se estaban oponiendo abiertamente a la presencia de dichos cuerpos armados en la región. Pero la violencia del enemigo paramilitar no se agotó en la eliminación física de los wayús; también se vulneraron referentes culturales que se consideraban sagrados, es decir, intocables en el marco de la guerra, como es el caso del cementerio, de las desapariciones de los muertos y de la violencia sexual contra las mujeres. En este sentido, la violencia física y la vulneración de pilares culturales del pueblo wayú son, siguiendo el lenguaje schmittiano, las expresiones más contundentes de una enemistad que alcanzó su extremo más radical.

Lo anterior se apoya en que, desde la teoría de Schmitt, el momento político por excelencia es aquel en el que el 
enemigo se revela como tal, ya que es allí donde se hace explícita la amenaza a la forma de vida propia, y con ello, se pone de presente la tensión entre amigos y enemigos. En palabras de Heinrich Meier, "son los momentos en los que el enemigo se percibe, se reconoce como la negación de nuestro propio ser, del destino particular, los momentos en los cuales, en intrínseca relación con ello, se reconoce la propia identidad, que adopta una forma visible" (Meier 2008, 47). Así, por un lado, cuando el enemigo se identifica, esto es, cuando se reconoce que hay otro que amenaza con extinguir la forma de vida propia, el antagonismo político se hace patente. Y, por otro lado, esa explicitación de la enemistad es al mismo tiempo un reconocimiento de la propia forma de vida: frente a ese otro que amenaza con eliminar mi existencia, yo ratifico mi forma de vida, la defiendo. Para que este momento político de identificación y reconocimiento del enemigo se dé, la posibilidad de la guerra siempre tiene que ser una constante, pero no es necesario que se haga efectiva. No obstante, en el caso de bahía Portete se hizo efectiva; no sólo el enemigo político se reveló al comenzar a codiciar un territorio que era constitutivo de la comunidad wayú, sino que además llevó a cabo una batalla cuerpo a cuerpo con crudeza y sevicia. Si la guerra es un presupuesto a partir del cual se mide la intensidad del antagonismo político en los casos concretos, se puede decir que en bahía Portete la oposición amigo-enemigo alcanzó niveles de intensidad muy altos, en la medida en que, con el fin de ratificar su modo de vida y de negar absolutamente el valor de la existencia wayú, los 
paramilitares recurrieron a la violencia extrema para acabar con el enemigo.

\section{Enemigo verdadero y enemigo absoluto: el conflicto de bahía Portete y la guerra de partisanos}

¿Cómo da cuenta Schmitt de este tipo de enemistades radicales en las que los niveles de violencia son extremos y en las que no parece haber posibilidad de conciliación alguna? ¿Se deben aceptar y reconocer como enemistades posibles, inevitables e insuperables dado el carácter esencialmente conflictivo del mundo humano? En un comienzo, para responder estas cuestiones se puede apelar a Schmitt en cuanto teórico del conflicto: de acuerdo con él, “[...] todas las teorías políticas en sentido estricto suponen al hombre como 'malo', o sea que lo consideran un ser extremadamente problemático, más bien 'peligroso', y dinámico” (Schmitt 1939, 207). En contraste con el liberalismo que presupone un hombre esencialmente "bueno", las teorías políticas que, según Schmitt, tienen un valor político en tanto que se sustentan sobre el conflicto y el antagonismo, parten de una concepción antropológica "pesimista", en el sentido en que ven al conflicto como una experiencia insuperable de las relaciones humanas. ${ }^{13}$ Esta condición de "insuperabilidad"

13 En relación con la manera como Schmitt se refiere a las concepciones antropológicas del liberalismo se han planteado varias críticas; en particular, una de las más destacadas indica que no es cierto que el liberalismo parta de un hombre esencialmente "bueno", sino que, al igual que Schmitt, las teorías liberales admiten la dimensión conflictiva de las relaciones humanas. Para profundizar en esta discusión ver Holmes (1999) y Herrera (2008). 
se puede explicar a partir de la distinción que plantea Mouffe entre "lo político" y "la política": mientras que "la política" remite a una serie de prácticas e instituciones que tienen como fin regular y organizar a las sociedades humanas, "lo político" se define desde lo ontológico, es decir, desde lo que constituye el ser mismo de lo humano (Mouffe 2009, 16). Ser humano no puede pensarse sin ser político, es decir, sin el conflicto. De ahí que sea una condición insuperable: en la medida en que es constitutiva del ser humano mismo, no puede evitarse. Preguntarse por lo político es indagar por lo que es esencial al hombre y a su manera de estar en el mundo, y esto, para Schmitt, es el conflicto.

La interpretación que Leo Strauss hace del concepto de lo político de Schmitt apunta en una dirección similar a la de Mouffe. De acuerdo con Strauss, Schmitt retoma de Hobbes el concepto de estado de naturaleza para fundamentar su noción de lo político y, más específicamente, la antropología que está en su base: en tanto que el estado de naturaleza se define por ser el status belli, el énfasis en el conflicto como condicionante de las relaciones entre los hombres se pone de presente. De nuevo, no se trata de que la lucha en sí misma sea lo políticamente relevante, sino de que en el estado de naturaleza, el comportamiento humano se encuentra condicionado por esa posibilidad real de la eliminación física. Según Strauss, el hecho de que el concepto de estado de naturaleza pueda ser tomado como lo que Schmitt cataloga de propiamente político, indica que "[...] lo político es un estatus del hombre; más precisamente, es el estatus, en tanto es el estatus 'natural', fundamental y extremo del hombre" 
(Strauss 2008, 143). El conflicto, la posibilidad de la guerra y de la eliminación física son el estado natural del ser humano, o en otras palabras, son elementos constituyentes de la naturaleza del hombre. De hecho, Strauss afirma que a partir de los planteamientos de Schmitt es posible ubicar a lo político como el destino humano (Strauss 2008, 161), en el sentido de que allí se pone en juego su existencia misma y el enemigo plantea un reto y una amenaza que no se puede pasar por alto si se pretende mantener el modo de vida propio. ${ }^{14}$ Así, tanto para Mouffe como para Strauss, el concepto de lo político schmittiano se sustenta sobre una preocupación por identificar el ser mismo de lo humano, de lo que no puede escapar todo aquel que se declare humano: ${ }^{15}$ el conflicto.

14 Strauss es consciente de las diferencias existentes entre Schmitt y Hobbes con respecto a su concepción de lo político, y en particular, de la noción de estado de naturaleza: mientras para Hobbes el status naturalis supone la guerra entre individuos, para Schmitt, se trata de guerra entre grupos o unidades políticas. De igual manera, en la teoría de Hobbes el estado de naturaleza debe ser superado con miras a consolidar un estado civil, el cual se plantea como opuesto al estado de guerra constante y de inseguridad proporcionado por el estado de naturaleza (Strauss 2008, 142-143); en cambio, para Schmitt, el conflicto no se puede superar: si bien se pueden establecer regulaciones sobre él, siempre formará parte de la naturaleza humana. Sin embargo, a pesar de estas distancias conceptuales, a Strauss le interesa elucidar por qué, para Schmitt, Hobbes se presenta como un pensador estrictamente político, y su respuesta es que el concepto de estado de naturaleza refleja lo que Schmitt busca plantear con respecto a la naturaleza humana: que el hombre no puede escapar a su naturaleza conflictiva, y en últimas, a su naturaleza política.

15 A partir de esto se puede señalar que quizás la preocupación de Schmitt por la despolitización que se promueve desde el liberalismo es que el "destino humano” (en términos de Strauss) o lo propiamente humano se está neutralizando o ignorando. 
Si el conflicto es inherente e insuperable en las relaciones entre humanos, parecería, entonces, que las enemistades radicales y violentas en extremo (como las que se plasmaron en la masacre de bahía Portete) son inevitables. No obstante, Schmitt no estaría satisfecho con esta afirmación. Si, por un lado, Schmitt puede ser caracterizado como un pensador del conflicto (Serrano 2002, xii) -tal y como lo he hecho hasta aquí-, por otro lado, también puede caracterizársele como un pensador del orden (Fernández Vega 2002, 43), que aboga por la acotación de la enemistad con el fin de garantizar el mantenimiento de la seguridad de las unidades políticas. En efecto, el conflicto es una dimensión constitutiva de lo que significa ser humano, pero si este no se regula, si la vida humana se enmarcara en un estado de guerra y violencia permanentes, esto supondría la extinción absoluta de las unidades políticas. El concepto que, para Schmitt, permite conciliar el compromiso hacia una antropología que conciba al conflicto como lo más propio de la naturaleza humana con la idea de que la enemistad debe acotarse para mantener el orden es el de enemistad verdadera ${ }^{16}$. Al hablar del enemigo verdadero, Schmitt piensa concretamente en un enemigo que es reconocido como tal y, particularmente, un enemigo con el que se mantienen las distinciones del derecho de guerra clásico.

16 En algunas traducciones la expresión “enemistad verdadera” es reemplazada por “enemistad real”. Por ejemplo, en Serrano (2002). 
De acuerdo con esto, la enemistad verdadera :

Conoce distinciones inequívocas, en especial, la diferencia entre guerra y paz, de combatientes y no combatientes, de enemigo y criminal. La guerra se hace de Estado a Estado, como una guerra de ejércitos regulares estatales, soberanos, portadores de un ius belli, que se respetan, incluso en la guerra, como enemigos, y que no se discriminan mutualmente como criminales, de tal manera que una conclusión de paz queda siempre posible, e incluso suele ser el fin normal y supuesto de una guerra. (Schmitt 1966, 18-19) ${ }^{17}$

El enemigo verdadero es aquel con quien se pueden establecer treguas y, más importante aún, es quien se reconoce como enemigo legítimo, como un igual que, a pesar de ser una amenaza y de encarnar la posibilidad o la realidad de la guerra, es un enemigo justo, pues se le concede el derecho a declarar la enemistad. Según Schmitt, los Estados son los que tienen esta categoría de enemigos verdaderos en tanto poseen el ius belli, es decir, el derecho a hacer la guerra y a tener la potestad sobre el criterio amigo-enemigo. De

17 Con respecto a esto, a partir de la argumentación de Michael Walzer, se puede afirmar que una enemistad acotada como la que defiende Schmitt debería suponer que las unidades políticas tengan el ius ad bellum y el ius in bellum. La primera noción remite al derecho a entablar la guerra, el cual se mide por las "razones que tienen los Estados para entrar en combate" (Walzer 2001, 51); así, una unidad política tiene el derecho a declarar la guerra cuando está actuando en legítima defensa, por ejemplo. Por otra parte, el ius in bellum se refiere al "derecho en la guerra", esto es, a que se garantice el cumplimiento de unas normativas y regulaciones durante la ejecución del combate. Con estas dos condiciones, la guerra estaría acotada y regulada. 
acuerdo con esto, la unidad política por excelencia es el Estado, ya que sobre él recae la decisión fundamental de, por un lado, determinar quién es el enemigo y, por otro, declarar o no la guerra. Esta tesis se expresa en el siguiente pasaje de El concepto de lo político: "Al Estado, en cuanto unidad sustancialmente política, le compete el jus belli, o sea la posibilidad real de determinar al enemigo y combatirlo en casos concretos y por la fuerza de una decisión propia" (Schmitt 1939, 193). La cuestión de la decisión es de suma importancia en este contexto, pues es en virtud de ella que una unidad adquiere estatus político: con la identificación del enemigo, la comunidad se define a sí misma en términos de su oposición al “otro", al extranjero. Para Schmitt, el hecho de que en una coyuntura concreta la unidad política se encuentre amenazada supone una tensión a partir de la cual, si no se decide quién es amigo y quién enemigo, la existencia misma de la unidad se pone en duda.

No es fortuito que Jorge Dotti se refiera a la decisión como un "acto vital" (Dotti 2002, 22), precisamente porque en ella se pone en juego la existencia de la comunidad política. Si no se decide frente a la situación de crisis, si no se identifica al enemigo, el estatus político de la unidad política se pierde al no tomar las riendas de su existencia con la identificación del otro amenazante y, en este proceso, con la explicitación de lo "propio". Y es que, en efecto, la decisión implica lo que Dotti, siguiendo a Max Stirner, llama la "mismisidad": "Schmitt encuentra en Stirner una apología de la mismisidad más personal que distingue al ser humano como voluntad decisoria, como actor que, al decidir, cumple 
el gesto distintivo de su existencia en las condiciones en que lo pone el drama de la historia" (Dotti 2002, 25). Decidir es identificarse con una forma de vida y defenderla frente a la amenaza que representa el otro. Si la decisión no se lleva a cabo, si el enemigo no es identificado, la forma de vida propia no se hace explícita, y esto conlleva a que la unidad política se pierda, pues sin la "mismisidad" inherente al proceso de enfrentarse al otro, sin la explicitación y defensa de la propia forma de vida, no hay existencia política. Sin una "voluntad decisoria" que actúe en medio de una situación que exige tomar posición frente al criterio amigo-enemigo, el estatus político de la comunidad se pierde, ya que no hay existencia que defender frente al otro amenazante. En este sentido, la condición de posibilidad de la existencia política es la decisión; con ella, la unidad se define a sí misma, se hace explícita, en oposición al otro que es identificado como enemigo. Puesto en palabras de Schmitt: "mientras un pueblo existe en sentido político es él mismo quien debe decidir, al menos en el caso extremo -sobre cuya existencia es también él, sin embargo, quien decide-, acerca de la distinción entre amigo y enemigo. En eso consiste la esencia de su existencia política” (Schmitt 1939, 197).

De acuerdo con Schmitt, el Estado, sintetizado en la figura del soberano, es esa voluntad decisoria de la cual pende la existencia política. Y es que, en efecto, la decisión política no recae sobre un orden legal estatal, sino sobre un sujeto concreto: el soberano ${ }^{18}$. Como bien lo advierte Wilson

18 En Teología política Schmitt afirma: "Es soberano quien decide el estado de excepción [...] La decisión sobre la excepción es una decisión en el sentido 
Herrera, “[...] lo político concierne a las decisiones que son vitales para la comunidad política, y esas decisiones no son tomadas por leyes, sino por agentes políticos concretos" [traducción propia] (Herrera 2008, 95). El soberano se encuentra por encima del orden legal y tiene la potestad para suspenderlo en caso de que la defensa de la unidad política así lo requiera. En esta dirección, el conflicto efectuado desde la noción del enemigo verdadero es un conflicto entre Estados y, más específicamente, un conflicto que depende de las decisiones de los soberanos de cada Estado concreto. Son ellos, como cabezas de unidades políticas, quienes se reconocen como enemigos legítimos, quienes tienen el derecho a declarar la guerra o la posibilidad de negociar la paz. Siguiendo a Mary Kaldor, dicha concepción de que el Estado es la unidad política por excelencia en la medida en que tiene la potestad absoluta para señalar al enemigo y declararle o no la guerra es propia de la definición del Estado Moderno (Kaldor 2001, 31), en virtud de la cual “[... ] el interés del Estado se convirtió en la principal legitimación de la guerra, dejó de ser posible defender por medios violentos

amplio de la palabra” (Schmitt 1933, 23). El soberano es quien tiene la potestad para decidir el curso de acción en el momento en que la existencia de la unidad política se encuentre amenazada; en ese contexto de "estado de excepción" las normas del orden jurídico vigente son puestas en suspenso y el poder absoluto para decidir las medidas a tomar con el fin de defender la forma de vida propia recae en el soberano. En palabras de Schmitt, el soberano "[...] decide si existe el caso de excepción extrema y también lo que ha de hacerse para remediarlo. Se ubica fuera del orden jurídico normal y con todo forma parte de él, porque le corresponde la decisión de si la constitución puede suspenderse in toto" (Schmitt 1933, 24). 
las reivindicaciones de causa justa por parte de otros agentes no estatales" (Kaldor 2001, 33). La concepción estatista de lo político conlleva, entonces, a que el derecho de guerra se ubique sólo en el plano de los Estados, pues es esa guerra la que podrá permanecer acotada, en la medida en que se entabla entre enemigos legítimos que se reconocen unos a otros como iguales; sólo desde esa guerra entre enemigos verdaderos se podrá mantener la existencia y la estabilidad de las unidades políticas.

Pero el conflicto en bahía Portete, a pesar de ser político, pues se trató de una comunidad defendiendo su forma de vida, sus valores, su territorio, sus prácticas, etc. ante un extranjero que la amenaza, no tiene las características de lo que para Schmitt sería una enemistad verdadera. No se trata de una enemistad entre Estados soberanos, no hay regulaciones de ningún tipo sobre la manera de llevar a cabo la guerra y las partes enfrentadas no tienen el ius belli requerido para ser reconocidos como enemigos legítimos. Schmitt no era ingenuo: él presenció el surgimiento de diversos tipos de conflictos que no se reducían al modelo de la enemistad verdadera y al marco de los Estados Modernos soberanos. Justamente, su Teoría del partisano es un intento por capturar conceptualmente esos otros conflictos, las guerras de guerrillas o de partisanos, ${ }^{19}$ que desbordaban los referentes del concepto de lo político entendido en términos estatales. La

19 Los términos "guerra de guerrillas" y "partisanismo" van a ser tratados como equivalentes. Es preciso señalar que el concepto de "guerrilla” que se va a trabajar se restringe a la conceptualización de Schmitt y no está necesariamente vinculado con los usos que ha tomado la palabra en la actualidad. 
tesis más básica que Schmitt plantea frente al modo de operar de los partisanos es que estos luchan irregularmente (Schmitt 1966, 11). Tomando como punto de partida el concepto de "lucha regular", según el cual el conflicto legítimo es aquel que se da entre Estados soberanos (Schmitt 1966, 20), los partisanos no poseen ni el ius ad bellum ni el ius in bellum, es decir, su lucha no se percibe como legítima y no hay regulaciones sobre los modos de atacar o intimidar al enemigo.

Siguiendo a Schmitt, cuando de partisanos se trata no hay un soberano que tome la decisión sobre el criterio amigoenemigo o sobre la declaración de guerra, no hay aquí enemigos verdaderos o enemigos legítimos. Schmitt lo indica en los siguientes términos: "[...] la guerra queda acotada [con el derecho de guerra clásico], y el partisano está fuera del acotamiento. Incluso pertenece a su esencia y a su manera de ser el estar fuera de cualquier acotamiento. El partisano moderno no espera ni gracia ni justicia del enemigo" (Schmitt 1966, 19-20). Las guerras acotadas o reguladas implican ciertas expectativas frente a lo que el enemigo puede o no hacer y a las posibilidades de generar acuerdos o plantear treguas. Michael Walzer se refiere a esto al señalar que una guerra regulada establece distinciones para controlar la enemistad; por ejemplo, la distinción entre un acto de guerra y un acto criminal (Walzer 2001, 80) es fundamental en el momento de legitimar la lucha: mientras que, para Schmitt, el acto bélico se definiría en términos de un marco estatal en el que el soberano decide si hay guerra o no y bajo cuáles condiciones, el acto criminal es el uso de violencia no legítima para efectuar 
una lucha no decidida desde el Estado. ${ }^{20}$ De ahí que Schmitt afirme que los partisanos suelen ser catalogados de criminales, pues su operar no se inscribe dentro de las regulaciones establecidas por el derecho de guerra con base en el cual se define qué es un acto bélico legítimo y, por ello, su accionar violento es ubicado en el plano de lo criminal. Esta criminalización del accionar partisano representa, según Schmitt, la posibilidad de una guerra de aniquilación absoluta (Schmitt 1966, 20), en la medida en que sin normativas que controlen la conducta de los combatientes se presentan situaciones en las que "todo vale"; contra el criminal, contra el enemigo no legítimo, todos los medios de eliminación tienen cabida.

A pesar de que el partisano está por fuera del orden regular y precisamente por eso es tratado como un criminal, Schmitt reconoce que este combatiente "[...] lucha en un frente político [...]” (Schmitt 1966, 25), puesto que su reivindicación se vincula con la defensa de su forma de vida frente a un enemigo que la ataca. En relación con esto, Schmitt es enfático al señalar que el carácter del engagement político del partisano suele ser más intenso que el de los combatientes regulares porque estos últimos no están comprometidos directamente con su causa. Lo que dota de más intensidad a la lucha partisana es su carácter telúrico, el cual remite al hecho de que el partisano combate por la defensa de su tierra, sus costumbres y sus prácticas frente a un enemigo que

20 Otras de las regulaciones propias de las guerras acotadas son la diferenciación entre civil y militar (los civiles no pueden ser atacados en el marco de los enfrentamientos) (Walzer 2001, 193) o los derechos de los prisioneros de guerra o de los heridos en combate (Kaldor 2001, 41). 
las amenaza. De acuerdo con Schmitt, "la fundamentación del partisano en el carácter telúrico me parece necesaria para destacar especialmente la postura defensiva, es decir, la limitación de la enemistad en el espacio y para evitar la reivindicación absoluta de una justicia abstracta" (Schmitt 1966, 32). La reivindicación partisana está ligada, entonces, a la defensa de la tierra; ${ }^{21}$ de allí nace el carácter particularmente intenso de la enemistad: el partisano toma la defensa de su suelo con sus propias manos, no actúa en virtud de la decisión de un soberano y, por ello, su violencia es ilegítima, lo cual lo enmarca en un contexto de "todo vale". Su lucha lo compromete directamente: el partisano está dispuesto a “[... ] defender casa, familia y patria contra un invasor extranjero

21 Y más específicamente, siguiendo el vocabulario schmittiano, también podría decirse que la lucha partisana se articularía alrededor de la defensa del nomos. Schmitt define al nomos como el momento fundacional de la toma de la tierra; según esto, la toma de la tierra por parte de los hombres es el punto a partir del cual se articula todo derecho y orden posterior. En palabras de Schmitt, "la toma de la tierra es el arraigar en el mundo material de la historia" (Schmitt 2001, 469). La apropiación del espacio es, para Schmitt, el acto que funciona como condición de posibilidad de la historia y de la creación del orden humano, ya que es allí donde los hombres entablan su relación con el mundo y configuran su forma de vida propia. Monserrat Herrero López, por su parte, afirma que la creación del nomos implica una "homogeneidad sustancial", es decir, una forma de vida, unos valores y una relación con el mundo compartida por todos aquellos que forman parte del mismo territorio enmarcado en el nomos. En palabras de Herrero López, "la 'homogeneidad sustancial' significa aquí igual configuración de un nomos. Los pueblos con un nomos común excluyen la posibilidad de la enemistad entre ellos [...] El modo de ser de un pueblo está configurado por el espacio, por las costumbres y por su historia" (Herrero López 1997, 282). El nomos remite, en últimas, a una historia, unas prácticas y unos valores compartidos por los grupos humanos en su interior. 
[...]” (Schmitt 1966, 44) y a recurrir a todos los medios posibles para garantizar la existencia de su forma de vida.

En este contexto, el conflicto en bahía Portete parece tener más rasgos de una lucha partisana que de una guerra regular. Los wayús ratifican y defienden su forma de vida y su territorio en el momento en que se oponen abiertamente a la lógica paramilitar de conquista territorial. Esta no es una disputa llevada a cabo por un ejército que represente la voluntad decisoria del Estado colombiano ni hay normativas o acotamientos cuando de acabar con esa amenaza extranjera se trata. Sin embargo, en este punto, el caso exige que se tomen en cuenta algunas particularidades importantes en su caracterización: según el antropólogo Weildler Guerra Curvelo, en la sociedad wayú "el conflicto es visto como algo natural y cotidiano; como algo en lo que los seres vivos se ven ineluctablemente inmersos" (Guerra 2002, 157). En efecto, como parte del orden y la legislación wayú, se contempla el conflicto entre los apushi o las unidades familiares ${ }^{22}$

22 Siguiendo a Ochoa Sierra, "los wayús están organizados en clanes que se dividen por linajes, según su ranchería. La descendencia es muy importante para ellos, pues su organización social se basa en los lazos de parentesco: los matrilinajes locales (apushi) siguen siendo la unidad básica de cohesión social" (Ochoa 2011, 13). La organización social wayú se define por el parentesco y, en particular, por un parentesco determinado por la vía materna; es decir, los parientes cercanos de un individuo son los de la madre y no los del padre. Las rancherías se constituyen por ese parentesco matrilineal, en la medida en que son grupos de ranchos que comparten lazos familiares y que juntos forman una unidad familiar. Ochoa Sierra también advierte que matrilineal no significa matriarcado: aunque " [...] la autoridad, bienes y descendencia se transmiten por la vía materna [...]" (Ochoa 2011, 14), la figura de autoridad que, en el caso de las sociedades occidentales se representa por el padre, es, en el caso wayú, el tío materno, es decir, el hermano de la madre. Por otra parte, es importante resaltar que los lazos de solidaridad 
como una situación cotidiana y natural. Por esta razón, los códigos de guerra wayú tienen normativas precisas para solucionar las disputas que se presentan constantemente entre las distintas unidades familiares que conviven en el territorio ancestral. Según Guerra, los conflictos entre los wayús usualmente están relacionados con el tema del control territorial o de la distribución de los recursos, con la competencia para alcanzar cargos de autoridad, con el hurto de ganado o con homicidios (Guerra 2002, 86). Justamente, la disputa por el puerto de bahía Portete no comenzó con la llegada de los paramilitares, previamente se había generado un conflicto “[...] entre Chema Bala, su familia y las familias Fince Epinayú, Uriana Fince y Ballesteros Epinayú en torno a quiénes eran los propietarios del puerto" (Colombia, Centro Nacional de Memoria Histórica 2010, 140-141). En principio, en la medida en que dicha disputa era entre unidades familiares wayús se apeló a los códigos de guerra de este pueblo para buscar una solución.

El procedimiento regular aplicado por los wayús para la resolución de conflictos especialmente agudos (como lo fue el conflicto por el puerto en bahía Portete) comienza por el

entre los miembros del apushi o unidad familiar son muy fuertes; de hecho, si un individuo se ve involucrado en una disputa con otro perteneciente a otro linaje, se considera que este es un conflicto no entre individuos, sino entre los apushi. Es en este sentido en que Ochoa Sierra afirma que en el pueblo wayú "[...] el sentido colectivo prima sobre el individual" (ibid.), ya que la persona no se define por su individualidad, sino por su pertenencia a un linaje determinado. Por último, es preciso advertir que los apushi funcionan como unidades autónomas; aunque se establecen constantemente alianzas, negociaciones y se comparten recursos y espacios con otros apushi, cada unidad familiar es independiente de las otras. 
envío de un palabrero (putchipu'u) que opera como el intermediario enviado por la familia directamente afectada, con el fin de solicitarle a la familia agresora una compensación económica por la afrenta cometida (Guerra 2002, 117). Esta retribución ofrecida por los agresores debe corresponder con el estatus social de la familia afectada: si la familia afectada posee muchos bienes, tiene muchos miembros y alianzas con otras familias poderosas, el pago por el daño debe ser más alto que si se tratara de una familia de bajo estatus. Cuando las partes enfrentadas no logran conciliar a través del palabrero, la segunda opción de compensación por los daños cometidos es la venganza (Guerra 2002, 150). En este caso, el conflicto tiende a hacerse más intenso a medida que involucra enfrentamientos cuerpo a cuerpo, pero esta vía de acción se considera legítima en el orden wayú. Sólo hay dos condiciones inviolables en el marco de la guerra wayú: las mujeres no pueden involucrarse de ninguna manera en los combates cuerpo a cuerpo y los cementerios no pueden ser profanados. Como lo indica el testimonio de una víctima de la masacre: "el Wayúu tradicionalmente es un pueblo de guerreros y muchos de sus conflictos internos han sido resueltos a través del uso de armas. Sin embargo, por más sangrientas que han sido estas guerras, los Wayúu siempre han manejado un estricto código de honor y una ética de guerra que no acepta ni la muerte de mujeres y niños ni la profanación de los cementerios" (Desde el desierto 2007, 51).

Una de las lecturas que atraviesa varios testimonios de las víctimas de la masacre enfatiza en el hecho de que "los principios de guerra y los códigos de honor que caracterizan 
los conflictos wayuu han sido pervertidos y desvirtuados por el accionar paramilitar" (Desde el desierto 2007, 29). Los paramilitares se muestran ante los wayús como un enemigo carente de legitimidad, ya que su accionar contradice los códigos de guerra wayú y constituye un daño que desborda los referentes de la guerra, la reparación y la normatividad de esta comunidad indígena. La violación sexual a mujeres, el desmembramiento de sus cuerpos y la profanación a los cementerios son prácticas prohibidas en el marco de la guerra wayú y su ejecución deslegitima totalmente al enemigo. Aquí, el término "deslegitimar" remite al hecho de que el otro deja de ser visto como un enemigo honorable, como un igual, y se convierte en una amenaza que debe y puede ser eliminada prontamente y a través de cualquier medio posible. Otro testimonio de una víctima de la masacre expresa bien esta idea de los paramilitares como enemigos no legítimos: "en nuestros días lamentablemente no podemos acudir a la putchi [intermediación por la vía del palabrero], o palabra Wayuu, porque no hay una contraparte con honor con quien conciliar, así mismo tampoco podemos acudir a la guerra porque nuestras guerras tienen límites éticos y llevan implícito el respeto por lo sagrado, cuestión de la que no entienden los paramilitares" (Desde el desierto 2007, 16). Este lenguaje de la guerra wayú tiene ciertas similitudes con lo que, desde Schmitt, se definía como una guerra acotada. Con la salvedad de que para Schmitt el conflicto regulado sólo puede presentarse en un marco estatal con un soberano como cabeza, las regulaciones de las disputas entre los wayús también conocen distinciones parecidas a las del derecho 
de guerra clásico (combatiente-no combatiente, enemigo legítimo-enemigo no legítimo), así como la posibilidad de la tregua, de la compensación o de la negociación. En este sentido, es posible decir que el enfrentamiento con los paramilitares vulneró este marco de guerra regular wayú al dinamitar los pilares sobre los que se fundaba. Siguiendo de cerca a Schmitt, el rompimiento de los códigos de guerra y de las normativas que la regulan conlleva al olvido de la enemistad verdadera y al paso a la enemistad absoluta.

Para explicar la noción de "enemigo absoluto" generalmente se apela a las guerras de religión: "en las luchas religiosas que precedieron a este derecho [el derecho internacional o el derecho de guerra clásico], cada uno de los bandos decía luchar por la 'causa justa' y, por tanto, se consideraba al rival como un 'enemigo absoluto', esto es, un hereje que transgrede valores universales” (Serrano 2002, 41). El enemigo absoluto es, entonces, aquel que no lucha por la defensa de su propia forma de vida, sino por salvaguardar valores que se piensan como universales y necesarios. Siguiendo este razonamiento, Schmitt alude a lo problemático que resulta el término "humanidad", el cual es usado como bandera en muchas guerras que se presentan como las luchas por mor de la humanidad. Según Schmitt, esta noción resulta engañosa en la medida en que se plantea una guerra en la que los defensores de la "humanidad" se muestran como los portadores de los valores que representan a todo aquel que es humano, mientras al enemigo se le niega su calidad de humano (Schmitt 1939, 201). Pero la humanidad no puede entablar ninguna guerra. Sostener esto, además de ser engañoso 
también es peligroso, pues apelar a una idea que apela a la universalidad de los valores conlleva a la deslegitimación y negación absoluta de formas de vida diferentes. Esto supone la exacerbación de la violencia y el resquebrajamiento de las distinciones propias del derecho de guerra clásico o de la enemistad verdadera: el enemigo absoluto no es reconocido como un enemigo legítimo, sino que es tratado como un criminal cuya existencia debe ser aniquilada, sin posibilidad alguna de entablar acuerdos o programar treguas. A pesar de que la defensa de valores absolutos y universales es una característica de la enemistad absoluta, quizás su rasgo más distintivo es el hecho de que lo político se convierte en un juego de suma cero: si el otro existe, yo no puedo existir; la existencia misma del otro representa la negación de mi propia existencia y viceversa. El concepto de lo político es llevado a su máxima radicalidad cuando se eliminan las regulaciones características de la enemistad verdadera y se pasa al desorden y radicalidad de la enemistad absoluta. El rompimiento de los códigos de guerra wayú y el ejercicio del monopolio de la violencia ilegítima por parte de los paramilitares supuso que el conflicto se desarrollara en un marco de irregularidad sin acotamiento alguno, en el cual el otro era percibido como una amenaza que había que enfrentar y eliminar con el fin de ratificar el modo de vida propio.

\section{Conclusiones: entre el teórico del conflicto y el teórico reduccionista}

Desde el lenguaje schmittiano, el conflicto paramilitareswayús puede ser caracterizado como un conflicto político: la 
comunidad wayú se enfrenta a los paramilitares para defender su existencia y los paramilitares amenazan la existencia wayú, pues esta descansa sobre la valoración del territorio como el lugar en el que se cohesionan sus prácticas y creencias. Son dos grupos enfrentados luchando por ratificarse a sí mismos a partir de la negación del otro. Pero además de ser un conflicto político, también debería añadirse que es un conflicto con rasgos de partisanismo: es un combate irregular, no hay acotamientos sobre la enemistad, los códigos de guerra wayús son trastocados, los paramilitares ejercen violencia ilegítima ${ }^{23} y$, por estas razones, la enemistad es absoluta, ya que todos los medios se muestran como plausibles a la hora de acabar con el enemigo (de ahí la violencia extrema de la masacre). Las herramientas conceptuales proporcionadas por la teoría de Schmitt permiten interpretar la disputa de bahía Portete, pues proveen un lenguaje que captura ciertas lógicas de guerra que parecen estar presentes en el caso y que llevaron a la configuración de un conflicto con reglas de juego no escritas y donde la eliminación del otro para garantizar la supervivencia de la comunidad política era la prioridad.

23 Con respecto a la violencia ilegítima de los paramilitares es preciso señalar que "la llegada de los paramilitares a la Alta Guajira se produjo durante el periodo en que supuestamente cumplían un cese de hostilidades como parte del proceso de desmovilización que se estaba acordando con el gobierno nacional en julio de 2003” (Colombia, Centro Nacional de Memoria Histórica 2010, 111). Así, el accionar violento de los paramilitares no sólo es ilegítimo por el hecho de violar el principio schmittiano según el cual el Estado es el portador por antonomasia de la violencia legítima, sino que también se suma el factor de que este grupo armado estaba en un proceso de negociación con el gobierno cuya condición básica era el cese al fuego. 
Ahora bien, como mostré a lo largo de este capítulo, es posible caracterizar a la teoría de Schmitt de dos maneras: por un lado, se puede decir que Schmitt es un pensador del conflicto, pero, por otro, es un pensador del orden y, particularmente, del orden representado por el Estado soberano. Estas dos perspectivas del concepto de lo político pueden conducir a dos interpretaciones diferentes del caso, las cuales entran en mutua tensión. En primer lugar, el compromiso con una antropología "pesimista”, según la cual el conflicto es una dimensión insuperable de la existencia humana, implica el interés por examinar los diversos tipos de conflicto político que se pueden presentar en diversos contextos y que pueden dar cuenta de diversas manifestaciones de la naturaleza conflictiva del mundo humano. La antropología schmittiana encuentra su punto de partida en la idea de Helmuth Plessner de que el hombre es una "cuestión abierta" (Schmitt 1939, 206), es decir, es un ser indeterminado al que no puede atribuírsele una esencia inmutable que dictamine su existencia de antemano. Como bien lo indica Serrano, rechazar el esencialismo supone inmediatamente que pueden existir diferentes órdenes sociales y no hay un único modelo a partir del cual todas las comunidades deban guiarse (Serrano 2002, 24). En virtud de lo anterior es que Schmitt sostiene que el mundo político es un pluriverso y no un universo, ya que la existencia de una unidad política depende de la existencia de las otras unidades; si existiera una suerte de "Estado mundial” y único no habría política en tanto no habría conflicto. En palabras de Schmitt, "la 
unidad política presupone la posibilidad real del enemigo y por consiguiente otra unidad política, coexistente con la primera" (Schmitt 1939, 200).

La noción de pluriverso, según Herrero López, trae consigo el reconocimiento de que el problema del otro, es decir, de la manera como nos relacionamos, enfrentamos, valoramos, juzgamos, esas formas de vida diferentes a la propia, es central para la filosofía política, pues toda reflexión sobre lo político debe estar vinculada con lo que Schmitt llamaría lo fáctico: desconocer la diferencia supondría, de acuerdo con esta visión, “[...] desconocer el mundo en que vivimos” (Herrero 1997, 340). Bajo esta perspectiva, el Schmitt del conflicto abogaría por estudiar los diferentes conflictos políticos y por examinar los tipos de enemistades que allí se gestan, las diferentes formas de enfrentarse con el otro y los diversos modos usados por las comunidades para ratificar la existencia propia. El concepto de lo político se alimentaría de este análisis y se pondría a prueba en el estudio de los conflictos reales; en este plano no se trataría de juzgar si el conflicto es legítimamente político en términos de que se desarrolle o no en el marco de los Estados, sino de analizar las distintas manifestaciones de lo político y la manera como estas proporcionan información sobre ese pluriverso que es el mundo humano. La preocupación central, en este contexto, es atender a cómo en el mundo real se articulan diferentes tipos de enemistad y de identidades políticas que tienen consecuencias sobre la organización y el desenvolvimiento de las comunidades concretas. 
En segundo lugar, Schmitt, en su calidad de pensador del orden, concibe al Estado como la unidad política por excelencia. Esta tesis es compatible con la noción de pluriverso hasta un punto concreto, pero llega a ser incompatible con ella en el momento en que Schmitt sostiene que al interior de los Estados no puede haber diferencia, sino que debe haber homogeneidad. La noción de Estado como la unidad política por antonomasia no dictamina la no pluralidad de formas de vida; todo lo contrario: para que exista lo político es preciso que el antagonismo entre unidades políticas derivado de la defensa de la propia forma de vida sea una lógica fundamental del desenvolvimiento del mundo social. Lo que sí dictamina esta idea de "unidad política" es el hecho de que el "enemigo interno" de los Estados debe ser combatido, ya que este resquebraja lo que podría denominarse la "unidad existencial” requerida para la decisión y para el estatus político de una comunidad. Siguiendo a Schmitt, la defensa de la forma de vida propia inherente a toda decisión política implica que la unidad decisiva, es decir, el Estado, es homogénea en su interior. La posibilidad de la decisión sobre el criterio amigo-enemigo presupone que aquel que decide -el soberano- representa y defiende los valores, normas o nociones de vida de la comunidad amenazada por el otro; si hay divergencia al interior del Estado, la decisión no parecería ser existencial, en la medida en que no se está defendiendo el modo propio de existir, sino una forma de existencia entre las otras posibles. Esto último resulta problemático para Schmitt porque acaba con la noción de 
"unidad"; el Estado se convertiría en un conglomerado de grupos defendiendo diversas formas de vida y la unidad decisiva requerida para la afirmación de la existencia frente al enemigo se perdería. ${ }^{24}$ Por esta razón, Schmitt defiende la "necesidad de pacificación interna" (Schmitt 1939, 193) como garantía del mantenimiento de la unidad política presta para la decisión frente al criterio amigo-enemigo. A este Schmitt estatista no le interesaría el carácter de los conflictos al interior de las unidades políticas, pues estos sólo parecen amenazar la soberanía y el estatus político de los Estados. ${ }^{25}$

Entonces, mientras, por un lado, el concepto de lo político de Schmitt abre la posibilidad para estudiar y analizar diversos conflictos y distintas formas de enemistad, por el otro, juzga las disputas internas de los Estados como conflictos no legítimos que deben ser erradicados. Esto último imposibilita la comprensión de las rivalidades internas con base en las herramientas dadas por las nociones de enemigo, amigo, conflicto y antagonismo, ya que, de entrada, las tensiones internas son vistas como no legítimas. Iris Marion Young catalogaría esta última postura como reduccionista: de acuerdo con esta pensadora, "el reduccionismo [...] consiste en la tendencia de la teoría política moderna a reducir

24 De ahí que Schmitt critique fuertemente a la democracia (Serrano 2002, 54-70) y, en particular, a la democracia liberal (Mouffe 2003a).

25 Aunque al Schmitt estatista no le interesaría el conflicto interno, al Schmitt como teórico del conflicto sí le interesaría y, de hecho, con la teoría del partisano, Schmitt pone de manifiesto la centralidad de las disputas al interior de las unidades políticas en el momento de pensar en lo político. Esto será estudiado con mayor detalle en el siguiente capítulo. 
los temas políticos a una unidad y a valorar lo común o lo idéntico por encima de lo específico y lo diferente" (Young $2000,12)$. Una filosofía política reduccionista como la que se articularía alrededor de la concepción estatista de Schmitt no puede dar cuenta de las diferentes variables que entran a jugar en los conflictos internos de los Estados ni de la forma como estas revelan nuevas enemistades que pueden enriquecer o imponerle retos al concepto de lo político. Bajo la concepción reduccionista, la disputa de bahía Portete se consideraría un conflicto interno del Estado colombiano al que sería preciso dar solución a través de la homogenización: tanto paramilitares como wayús representarían diferencias que amenazan con acabar la soberanía del Estado colombiano. ElSchmitt reduccionista no prestaría atención al análisis de los actores del conflicto por el puerto, a las enemistades que allí se gestaron o a los factores que llevaron a la consolidación de un conflicto absoluto en el que la violencia extrema fue la constante. Asumir la posición reduccionista implicaría, entonces, la ceguera ante los diferentes matices y retos que el conflicto de bahía Portete podría introducir en la reflexión sobre lo político y, más aún, no permitiría entender las complejidades del caso en relación con los conceptos de enemigo, guerra, unidad política, etc.

En el siguiente capítulo, se apelará a Schmitt en cuanto teórico del conflicto, con el fin de tomar las herramientas dadas por la teoría de lo político y darle un lenguaje a una situación que fue central en la disputa de bahía Portete y que, desde una concepción reduccionista, no sería considerada como parte de lo político, a saber: los paramilitares se aliaron 
con miembros de la misma comunidad wayú para atacar a sus enemigos indígenas. El examen de cómo este enemigo interno entra a participar en el conflicto y, al parecer, a agudizarlo será realizado a partir de la noción de "guerra entre hermanos" propuesta por Derrida. A grandes rasgos, las reflexiones del filósofo francés le exigirán al concepto de lo político la incorporación de un lenguaje que capture lógicas de hostilidad absoluta no consideradas en el marco de una visión reduccionista del conflicto. Esta perspectiva abonará el terreno para los interrogantes que se plantearán en el último capítulo con respecto a los métodos de intimidación utilizados por los paramilitares para acabar con la forma de vida de sus enemigos wayús. 


\section{Capítulo II \\ El hermano wayú: irreductibilidad, diferencia y desnaturalización}

Este capítulo tiene por objetivo complejizar y problematizar la lectura del caso de bahía Portete a partir de un concepto que, para Derrida, reta a la conceptualización schmittiana y la lleva a replantearse y repensar sus límites: el concepto de hermano. Derrida señala que el Schmitt reduccionista no proporciona herramientas suficientes a la hora de pensar en las enemistades que se pueden generar al interior de las unidades políticas, pues sólo las concebiría como fallas del Estado en el momento de consolidar su soberanía absoluta. Para el filósofo francés, este acercamiento a los conflictos internos de las comunidades no permite preguntarse por la manera como se configuran las enemistades y los conflictos al interior de las unidades políticas, y por cómo estos elementos pueden enriquecer o cuestionar el concepto de lo político. En este contexto, por medio del examen de la teoría del partisano, se mostrará que la noción de hermano resulta crucial para dar cuenta del tipo de enemistad que se gestó entre paramilitares y wayús en el caso de bahía Portete y, en este sentido, la lectura reduccionista de lo político se queda corta en el momento de caracterizar las complejidades presentadas por el caso. 


\section{¿Quién es el enemigo paramilitar? La pureza conceptual de Schmitt y los retos al concepto de lo político}

De acuerdo con Ochoa Sierra, "[...] la hegemonía del BN [Bloque Norte de las AUc] no siempre se dio por la fuerza” (Ochoa 2011, 44). Años antes de la masacre de abril de 2004, los paramilitares operaron con dos estrategias de conquista territorial: en primer lugar, "[...] aprovecharon las peleas entre clanes y se presentaron como apoyo para los hombres wayús que ejercían como contrabandistas" (Ochoa 2011, 60). En efecto, en la medida en que los clanes wayús de bahía Portete habían manejado el negocio del contrabando desde la colonia, las disputas por el puerto y por el dominio del territorio habían sido constantes; los paramilitares, en principio, apoyaron con armas y recursos a ciertos apushi wayús como parte de guerras intrafamiliares y presentaron su lealtad a las familias de Mario Cotes y Luis Ángel González. Con este precedente, se comenzaron a entablar diversas alianzas entre wayús y paramilitares en las que los primeros acudían a los segundos para protección o defensa de sus intereses y posesiones territoriales. ${ }^{26}$ Sin embargo, a medida que los paramilitares adquirían mayor poder, lo que en un comienzo era una relación de subordinación en la que los intereses

26 La estrategia de presentarse como grupos de "defensa privada” que protegen los intereses y las posesiones de ciertas élites regionales es típica del accionar paramilitar en Colombia (Romero 2003, 24). La protección ofrecida por los grupos paramilitares no es desinteresada; por el contrario, responde a intereses económicos precisos, y sobre todo, al interés por monopolizar las actividades de la región ocupada a través de la alianza con hombres poderosos. 
wayús imperaban, terminó por convertirse en su opuesto: los paramilitares empezaron a asesinar a los contrabandistas wayús con quienes se habían aliado (por ejemplo, Mario Cotes y Luis Ángel González fueron asesinados y los paramilitares se quedaron con sus tierras) con el fin de obtener su estatus y poder y, en algunos casos, los mismos wayús terminaron trabajando para los comandantes del Bloque Norte, como lo muestra la situación de Chema Bala, hombre wayú que, junto con su familia, contribuyó a la planeación y ejecución de la masacre en bahía Portete.

Esta primera forma de intervención paramilitar en el territorio estuvo acompañada de otra estrategia: la inserción en las redes de parentesco wayú. A la par que se iban generando alianzas con las familias contrabandistas de más renombre en la zona de la Alta Guajira, los paramilitares también entablaron vínculos matrimoniales con las mujeres wayús. Este hecho es particularmente significativo por dos razones principales: por un lado, siguiendo a Guerra Curvelo, para los wayús, el estatus y el poder son elementos de central importancia en la organización social. Las tierras, las riquezas y los bienes contribuyen a la generación de estatus de la unidad familiar y, como parte de este modelo, el hecho de que un apushi tenga la capacidad de proteger sus propiedades por medio de las armas es una característica básica en el momento de revelar el poder de la familia. De ahí que Guerra Curvelo se refiera a los momentos de conflicto wayú como un “escenario de generación de estatus” (Guerra 2002, 92), pues es allí donde se pone a prueba el poder de las unidades familiares enfrentadas: si la disputa se lleva a las armas es 
porque las familias en conflicto tienen tanto poder como para poseer ejércitos y defenderse; y si la disputa se resuelve desde la práctica de la compensación, los bienes materiales entregados a la familia afectada deben corresponder con su estatus o aumentarlo, es decir, antes de dar la compensación por los daños cometidos se debe reconocer públicamente el poder que tiene la familia víctima en la organización social wayú, y en virtud de esto, negociar la compensación material. En este sentido, la posesión de ejército propio, de armas, de bienes y de riquezas son todos elementos que expresan el poder y el estatus de la unidad familiar wayú.

La alianza con paramilitares y, más aún, la inserción de este grupo armado en las redes de parentesco indígenas por medio del matrimonio fueron factores que favorecieron la obtención de poder por parte de algunas familias. Los paramilitares se presentaban como hombres con armas y riquezas que podían ser útiles en la defensa de los intereses del apushi $i^{27}$, pero, en particular, el hecho de que se casaran con las mujeres wayús implicó que estos hombres poderosos empezaron a formar parte propiamente de las familias, y de esta manera el estatus del apushi aumentaba considerablemente. ${ }^{28}$ En palabras de Guerra Curvelo, “[...] la relación

$27 \quad$ El apushi es la unidad familiar wayú compuesta por la familia cercana que, en el caso de la organización matrilineal wayú, está compuesta por los parientes ligados a la madre (Ochoa 2011,31). Ver nota al pie 22.

28 A este respecto, Ochoa Sierra explica que, para denotar su poder, “[...] los paramilitares han ofrecido al tío materno de la mujer que desean -sea su esposa o compañera ocasional-dotes millonarias y tumas u otras piedras con gran valor simbólico" (Ochoa 2011, 67). El dinero y las joyas ofrecidas como dote aumentaban el poder y el estatus de la familia que las recibía y, en este sentido, 
con los miembros de la sociedad occidental creó a lo largo de la historia oportunidades económicas y políticas para el ascenso social de algunos grupos familiares Wayuu que se disputaban con otras unidades familiares extensas la preponderancia política y social de un determinado lugar" (Guerra 2002, 54-55). En el caso de bahía Portete, el grupo occidental que se unió por parentesco a los wayús era un grupo armado que tenía un ejército constituído y que aspiraba a conquistar el territorio y los recursos de la Alta Guajira para su propio beneficio. En esta dirección, a pesar de que las alianzas matrimoniales sí aumentaron el poder y el estatus de las familias wayús, el descenlace de los hechos en la masacre muestra que quienes obtuvieron mayor poder sobre el territorio, sus recursos y su población fueron los paramilitares y no los wayús.

Por otro lado, además de que los vínculos matrimoniales aumentaran el estatus y poder de las familias, también propiciaban unas lógicas de solidaridad que encajaban perfectamente con las dinámicas sociales wayús, pero que resultaron bastante problemáticas respecto a la adquisición de poder por parte de los paramilitares. La sociedad wayú define enfáticamente quiénes son sujetos de sus lealtades más inmediatas: en tanto que se trata de una organización social matrilineal, la familia cercana o los parientes de cada individuo son los de la línea materna; a ellos se les debe la lealtad y con ellos se articulan los lazos de solidaridad en la unidad

convertirse en esposa del paramilitar mejoraba la reputación no sólo de la mujer, sino de su unidad familiar. 
familiar. Según Guerra Curvelo, el momento de conflicto "[...] pone a prueba la existencia de lealtades, reciprocidades y hostilidades en el seno de cada grupo familiar extenso y entre éste y los otros grupos familiares indígenas" (Guerra 2002, 65). Cada individuo debe su lealtad a sus parientes del apushi y en los tiempos de disputa es cuando debe expresarla abiertamente. Con la inserción de los paramilitares en las redes de parentesco wayú, si un paramilitar entraba en conflicto con un apushi determinado, el apushi al que ahora pertenecía el paramilitar debía apoyar y ser leal a su pariente. Como bien lo indica el testimonio de una mujer wayú: “ya un hombre que sea miembro del grupo paramilitar, pues ya casado con una hija mía y me lo van a lastimar y yo no lo voy a permitir, porque él está casado con mi hija y es difícil, y ahí es donde vienen los enfrentamientos" (Ochoa 2011, 67).

¿Quién es entonces el enemigo paramilitar? ¿Es el extranjero, el otro, el arijuna? ¿O es el pariente, el aliado, el miembro de mi apushi? A lo largo del primer capítulo intenté definir a los actores en conflicto en términos de lo que, desde Schmitt, era el enemigo político, a saber: "el otro, el extranjero", para el cual "basta a su esencia que sea existencialmente, en un sentido particular intensivo, algo otro o extranjero [...]” (Schmitt 1939, 177). Pero, ¿qué pasa cuando el enemigo es un pariente que está inserto en las redes de parentesco de mi comunidad? En otras palabras, ¿ cómo entender el hecho de que el pariente o el aliado amenacen y rompan con los códigos propios de la forma de vida, que se supone, deben defender? ¿ Introduce esto nuevas variables al concepto de lo político? Siguiendo a Derrida, se puede decir 
que el planteamiento de estas preguntas en relación con un conflicto real vivido por grupos humanos concretos implica exigirle a la teoría de Schmitt la renuncia al reduccionismo y la apertura del concepto de lo político a los matices y retos que un caso real le pueda imponer.

Para desarrollar esta afirmación, Derrida objeta a Schmitt el estar obsesionado con la pureza conceptual de lo político. Esta tesis se explica, en un primer momento, por la distinción tajante de la conceptualización schmittiana entre lo público y lo privado: en lo público está el enemigo político (hostis), mientras en lo privado se encuentra ese enemigo personal (inmicus), hacia el que se dirigen pasiones y afecciones que no tienen repercusión alguna en la constitución de la enemistad pública. Puesto en otros términos, “[...] el enemigo político no sería forzosamente inamistoso, no alimentaría necesariamente sentimientos de enemistad respecto a mí, y recíprocamente [...] el sentimiento no tendría nada que ver con esto, ni la pasión, ni el afecto en general. He aquí una experiencia del amigo/enemigo totalmente pura, en su esencia política, de todo afecto, al menos de todo afecto personal [...]" (Derrida 1998b, 107). El enemigo público, y lo que es lo mismo, el enemigo político no necesariamente despierta mi odio, como sí lo hace el enemigo privado que no tiene relevancia política; es en este sentido en que es posible, bajo el modelo de Schmitt, amar al enemigo político, pues el sentimiento o las pasiones personales no afectan esa enemistad "pura”, es decir, esa enemistad que no traspasa la distinción entre público y privado y que es neutral frente a quién es el enemigo en su espacio privado. 
Bajo esta perspectiva, es posible entender cómo, para el Schmitt estatista, el partisano desborda los límites del concepto de lo político y constituye una desviación del mismo: la enemistad del partisano borra la distinción público-privado al propiciar una enemistad absoluta, esto es, al plantear al otro, al enemigo, como susceptible de ser odiado y exterminado de manera absoluta por todos los medios posibles. ${ }^{29}$ En la lucha partisana hay pasiones y afecciones que no respetan las regulaciones de la guerra clásica entre Estados ni el acotamiento -tan defendido por Schmitt- del concepto de lo político: el partisano es telúrico y, en este sentido, se compromete directamente con su causa, lo que en últimas quiere decir que su "ser", sus valores, sus prácticas, lo suyo están en juego en la guerra y va a defenderlos a toda costa. Aquí lo que Schmitt definiría como emociones o afecciones privadas tiene un peso decisivo para la configuración de la díada amigo/enemigo, pues el partisano se mueve en virtud de esos afectos al ver amenazada su forma de vida, o lo que Derrida llamaría, su oikos, su hogar. En efecto, a pesar de que el antagonismo propiamente político no tendría que

29 En este punto es preciso recordar que en el concepto de lo político, Schmitt define al enemigo político como hostis y no inmicus: "Hostis es aquel con quien libramos públicamente una guerra [...] y en esto se diferencia del inmicus, que es aquel con quien tenemos odios privados" (Schmitt 1939, 179). A lo que Derrida apunta es a borrar esa distinción que se entabla aquí entre lo público como el espacio ajeno a los odios o afectos privados y lo privado como el lugar donde sí se manifiestan odios y afecciones que no son propiamente políticas. Para Derrida, lo que Schmitt llama “odios privados” se encuentra en el centro de lo político y define el carácter de muchas enemistades, en particular, la que se desarrolla desde el partisanismo. 
depender de afectos u odios, en el momento en que surge una enemistad absoluta estos acotamientos no son tan claros: en la lucha partisana, los límites se violan constantemente y la manera de pensar en el otro-enemigo se encuentra atravesada por diversas concepciones, pasiones y afecciones que convierten al otro en un objeto de odio susceptible de la eliminación total.

El Schmitt reduccionista ve en el partisano, y en la subversión de los límites entre lo público y lo privado, desviaciones del concepto de lo político. Lo político, desde esta perspectiva, debe ser acotado, con el fin de que la hostilidad no involucre pasiones privadas y no desborde el marco de los Estados soberanos. En la medida en que el accionar partisano no encaja en este modelo, esta es una lucha que se sale de la norma, es una enemistad que contradice los principios del concepto de lo político definido en términos del antagonismo entre Estados. En este modelo está presente la obsesión por la pureza conceptual que Derrida señala: todo lo que no se acomode con el concepto "puro", con las distinciones claras que lo político acotado establece, es desviado, es contradictorio. A pesar de que Schmitt insiste en que su teoría muestra lo que es la realidad y la manera como se desenvuelven las relaciones humanas, aquí se logra evidenciar un compromiso con un deber ser de lo político, en tanto que se prescribe que lo político debe ser acotado, regulado y debe respetar las distinciones; de lo contrario, es desviación. Pensar en las realidades que no se ajustan a la norma como desviaciones o contradicciones implica ceguera: el concepto de lo político deja de ser sensible ante conflictos 
concretos, ante diversos modos en que se configuran enemistades, al juzgar y leer las disputas bajo el lente prescriptivo del estatismo y de las acotaciones del conflicto.

De acuerdo con Derrida, esa obsesión por la pureza del concepto no sólo es ingenua, sino además problemática. Ingenua porque la realidad humana demuestra constantemente que hay más enemistades "desviadas" que acotadas y problemática porque un concepto de lo político articulado de tal forma no es útil como herramienta para pensar los conflictos de un mundo que "[...] está entregado a nuevas violencias, a nuevas guerras, a nuevas figuras de la crueldad o de la barbarie [...]" (Derrida 1998b, 97). Y es que, en efecto, si seguimos el espíritu del Schmitt reduccionista, la enemistad que el caso de bahía Portete plantea, en la que ese otro que amenazaba la forma de vida propia resultó ser un aliado o un pariente, y en la que la enemistad absoluta es lo que prima, constituiría una desviación a la norma. Pero este "diagnóstico" reduciría la complejidad del fenómeno y no permitiría examinar cuidadosamente qué puede decir esa realidad sobre el concepto de lo político, cómo puede enriquecerlo o modificarlo, qué elemenos nuevos introduce. En últimas, en este punto, el caso mismo exige, para su comprensión, que el concepto de lo político se ponga a prueba a partir de lo que la realidad expone. Si el objetivo es dar cuenta de las nuevas formas de conflicto, de las nuevas hostilidades, hay que abandonar al Schmitt reduccionista comprometido con la pureza conceptual y tomar su reflexión sobre el conflicto como herramienta que es susceptible de ser enfrentada a la realidad y, en este caso particular, a la realidad vivida en 
bahía Portete. Con este fin en mente, Derrida introduce el concepto de "irreductibilidad", el cual permite concebir a lo político como un espacio sensible, receptivo y capaz de atender a los conflictos políticos del mundo contemporáneo.

\section{La irreductibilidad y la guerra entre hermanos}

La tesis central de Derrida con respecto a lo político pensado alrededor de la teoría schmittiana indica que la lucha partisana, en lugar de ser una desviación o una contradicción de lo político, en realidad lo afirma. Para entender esto, es preciso hacer algunos comentarios con respecto a la manera particular a través de la cual Derrida hace filosofía. ${ }^{30}$ Siguiendo a Richard Beardsworth, un principio fundamental del pensamiento derrideano es el de la irreductibilidad ${ }^{31}$; de acuerdo con este, la realidad es irreducible "[...] a todas las formas de organización (conceptual, lógica, discursiva, política, técnica, entre otras)" (Beardsworth 2008, 17). Para Derrida, todo intento por organizar o capturar conceptualmente la

30 Usualmente, se dice que la forma de hacer filosofía practicada por Derrida tiene el nombre de "deconstrucción". Sin embargo, quiero tomar distancia de este término porque esta palabra designa diferentes modos de operar en filosofía y en ciencias sociales que, en ocasiones, difieren considerablemente unos de otros y plantean distintas interpretaciones de lo propuesto por Derrida. En vista de que mi objetivo no es hacer una deconstrucción o discutir con las versiones que existen de ella, prefiero abstenerme de usarlo, para evitar equívocos o confusiones al respecto. En esta misma dirección, Richard Rorty ha planteado: "no veo una verdadera conexión entre lo que hace Derrida y la actividad a la que se llama 'deconstrucción'” (Rorty 1998b, 39), en la medida en que el término no logra dar cuenta de todas las herramientas y supuestos con los que opera Derrida en su filosofía.

31 Algunos lo traducen como “indecibilidad”, por ejemplo Mouffe(1998a). 
realidad y las contingencias que le son inherentes es fallido; siempre se queda algo por fuera, siempre hay algo que rebasa los límites impuestos por la organización. Por esta razón, el proceso de conceptualizar una realidad supone un acto de violencia (Beardsworth 2008, 19), puesto que es inevitable que haya exclusiones en el intento de unificar una realidad determinada por medio de conceptos. No obstante, a pesar de que la exclusión de los fenómenos diferentes al concepto sea un paso ineludible, la idea es comprometerse con la práctica de la "violencia menor", esto es, con una conceptualización que esté dispuesta a renegociarse y a abrir la posibilidad para que esas diferencias que no fueron capturadas puedan modificar o cuestionar el concepto y llevar a nuevas formas de capturar la realidad. ${ }^{32}$

32 Esta cuestión de la irreductibilidad ha sido ampliamente tratada por los comentaristas de Derrida en diversas áreas del pensamiento de este filósofo. En particular, se ha enfatizado en la irreductibilidad y la violencia inherentes a todo orden jurídico; al respecto, Drucilla Cornell afirma que "para Derrida, no hay sistema alguno que pueda establecerse por sí mismo como la única realidad. Pensar que cualquier sistema social, legal o de otro tipo, puede capturar toda la realidad social es otro mito, el mito de la presencia total" [traducción propia] (Cornell $2002,172)$. En este caso, se muestra la imposibilidad de capturar la realidad social a partir de un orden jurídico concreto; más adelante, Cornell mostrará que la instauración de una ley, por ejemplo, implica un acto de violencia en la medida en que siempre existirán fenómenos que se queden por fuera de su cobertura. Por otra parte, la irreductibilidad también ha sido un supuesto básico en las reflexiones de Derrida sobre la teoría lingüística y de los signos de Saussure; para profundizar en este asunto ver: Beardsworth (2008) y Kamuf (1991). En el plano de los análisis políticos, se ha dicho que "todo acto de fundación de una sociedad o polis va a estar marcado, para empezar, por el 'sî' que precede a toda actuación supuestamente inaugural” (Bennington y Derrida 1994, 239). En este sentido, la fundación de todo orden político supone la exclusión de realidades, actores e identidades que no se ajustan a lo que se definió como "propio" de la polis. De 
En el campo de lo político la irreductibilidad tiene unas consecuencias precisas. Siguiendo a Mouffe, a partir de esta noción es posible pensar en una filosofía política que sea más receptiva "[...] a la multiplicidad de voces que abarca una sociedad pluralista y a la complejidad de la estructura de poderes que implica esta red de diferencias" (Mouffe 1998, 32). En un comienzo, Derrida llama la atención sobre la violencia constitutiva de todo orden conceptual: todo concepto va a intentar dar cuenta de una realidad incapturable, va a intentar unificar fenómenos que no son unificables y, en este sentido, la determinación conceptual necesariamente excluye lo que no se ajusta a ella. Eso es, justamente, lo que pasa con el concepto de lo político de Schmitt: al intentar encontrar lo propiamente político a través del "[...] descubrimiento

manera similar, el análisis de Simon Critchley sobre la filosofia de Derrida enfatiza en la manera como el concepto de justicia participa de la irreductibilidad: teniendo en cuenta que todo orden político excluye realidades que no le son propias, se debe abogar por reducir la violencia inherente a este proceso por medio de la introducción de nuevos enfoques, nuevas demandas, nuevas exigencias y nuevos fenómenos a la noción de polis. Critchley afirma que "la justicia es una experiencia de lo indecible" (Critchley 1998, 76), en tanto que es un concepto que no logra capturar todas las exigencias sociales posibles, pero que siempre está abierto a ampliarse para cumplir con el compromiso de una política de la violencia menor. Esta propuesta de Critchley se articula desde el diálogo que se puede entablar entre la indecibilidad de Derrida y la ética de Levinas. Como se puede advertir, todos estos acercamientos a la irreductibilidad son útiles para entender cómo funciona esta noción; sin embargo, no encontré estudios que aborden específicamente la relación entre la irreductibilidad y el análisis del concepto de lo político de Schmitt. Los estudios nombrados anteriormente son útiles para entender el funcionamiento de lo irreductible en relación con áreas como lo jurídico o lo sígnico, pero no examinan lo que específicamente pretendo desarrollar aquí, a saber: el concepto de lo político de Schmitt y su problematización a la luz de ciertas realidades que no captura y que parecen ser parte fundamental de sus lógicas. 
y la fijación de las categorías específicamente políticas” (Schmitt 1939,176), se lleva a cabo una conceptualización que dictamina qué es lo político. Y al entender lo que es, se prescribe, al mismo tiempo, lo que no es. El partisano, la enemistad absoluta, las afecciones privadas no son, para el Schmitt reduccionista y estatista, elementos específicamente políticos. La crítica de Derrida apunta, no tanto a señalar esta "violencia" de la determinación conceptual (pues es inherente a todo intento por pensar conceptualmente una realidad), sino a advertir que el concepto debe ser susceptible de romper con sus propios límites para responder a las diferencias que existen efectivamente en el mundo real y que no se han capturado aún; aquí Derrida apela a Schmitt en cuanto teórico del conflicto: desde esta perspectiva, el concepto de lo político no es prescriptivo, sino que está pensado como un criterio que proporciona una clave de lectura a los conflictos reales, pero cuyo fin es enriquecerse y ponerse a prueba a la luz de las enemistades y los antagonismos que se den en las comunidades concretas. Siguiendo a Simon Critchley, se puede decir que Derrida se apoya sobre el pensador del conflicto que es Schmitt para "dilucidar [las] estructuras profundamente aporéticas o indecibles” (Critchley 1998, 72) de lo político; se trata, entonces, de pensar en lo político como una herramienta para acercarse a la realidad humana que es susceptible de ser modificada o retada en virtud de los matices que la misma realidad impone y que no han sido capturados por la conceptualización inicial. En este contexto, el caso de bahía Portete tiene una particularidad de la que Derrida ha dado cuenta desde el mismo concepto de lo 
político schmittiano, a partir de la teoría del partisano y, en particular, de la noción de stásis o guerra interna.

En el capítulo anterior se había señalado la tensión que existe en el pensamiento de Schmitt entre la defensa del mundo político como un pluriverso y el llamado a pacificar a los Estados en su interior en pro del mantenimiento de la unidad política soberana. Derrida afirma que la preocupación que parece estar en la base de esta contradicción es, precisamente, la posibilidad de que el concepto de lo político se desgarre, es decir, pierda sus límites y sus acotamientos con el surgimiento de un enemigo que impida la consolidación de una unidad política inquebrantable. En palabras de Derrida, "la idea que domina aquí es que un pueblo no puede hacerse la guerra a sí mismo, y que una 'guerra civil' no es jamás otra cosa que el desgarramiento de sí[...]” [subrayado mío] (Derrida 1998b, 110). El problema en este caso es que, si Schmitt es fiel a su propio concepto, no puede negar que el enemigo interno nace de las mismas lógicas impulsadas por lo político y no las contradice en absoluto. Lo que Derrida pretende aquí es, como lo diría Ernesto Laclau, “[... ] reinscribir los casos aparentemente desviados en la misma estructura lógica de la relación que estamos analizando" (Laclau 1998, 104), esto es, ubicar al enemigo interno en el centro de lo político, en lugar de excluirlo. El enemigo interno, entonces, no desgarra lo político, sino que lo afirma con mayor contundencia.

A partir de La República de Platón, Derrida define a la guerra interna de la siguiente manera: "el litigio (diaphorá) entre quienes comparten lazos de parentesco o de origen (oikeion kai syggenés: familia, casa, intimidad, comunidad 
de recursos y de intereses, familiaridad, etc.), es la stásis, la discordia o la guerra que se llama a veces civil” (Derrida 1998b, 112). Esto se opone a la guerra entre extranjeros o el polemos. En la teoría de Schmitt lo político como tal se ubicaría en el lado del polemos, mientras la stásis sería una desviación de lo político y se debería optar por la pacificación a fin de que la familia, lo propio, la comunidad o la unidad política no se fragmenten. Esta guerra interna sigue las lógicas de lo que Schmitt había postulado para el partisano: se trata de una lucha irregular, puesto que rompe con la definición de lo político como aquella enemistad verdadera que se da en el marco de los Estados, opera en virtud de una enemistad absoluta, en tanto que lo que está en juego es la defensa de los valores y prácticas más propias, más familiares. Por esta razón, la intensidad del enfrentamiento aumenta, pues lo que se ha definido como valioso y vital para una comunidad es amenazado por un enemigo que debe eliminarse, pero cuya particularidad radica en que es un miembro de la misma comunidad: este enemigo representa la diferencia dentro de una unidad que debería ser de iguales, en el sentido en que se deberían compartir y defender los mismos valores que definen lo propio de la comunidad, los que la hacen ser lo que es. Esta enemistad interna es sintetizada por Derrida en la figura del hermano: la stásis es el momento en el cual los hermanos de la misma comunidad política se declaran la guerra y se dan muerte unos a otros.

¿Quién es esta figura del hermano? ¿Y cómo puede estar vinculada con la enemistad? Una de las definiciones de amistad que proporciona el Lisis de Platón y que es usada por 
Derrida indica que "[...] el amor, la amistad, el deseo apuntan, al parecer, a lo más propio y próximo [...] Así pues, si vosotros sois amigos entre vosotros, es que, en cierto sentido os perteneceis mutuamente por naturaleza [subrayado mío]" (Lisis. 221 e). Lo mismo aplica para el hermano: el hermano es con quien comparto mi forma de vida, es mi próximo y nos pertenecemos mutuamente por el hecho de que tenemos el mismo origen, las mismas prácticas, los mismos valores. $M i$ hermano es "lo propio", es mi naturaleza, es el que me conoce y me es leal en razón de que compartimos el mismo modo de vida. De ahí que la traición del hermano sea la más desgarradora: el hecho de que $m i$ hermano no responda a mis expectativas y me haga la guerra implica el incremento de la enemistad porque en el hermano, con todo lo que él encarna, está la vida de la comunidad, está en juego la unidad, la fraternidad y la cohesión del grupo que denomino mi familia, mis iguales, mi oikos. La guerra con el hermano supone, entonces, el quebrantamiento de esa fraternidad; por ello, esa es la "guerra fratricida" (Derrida 1998b, 171): el enemigo más fratricida y desgarrador se encuentra en lo familiar, en lo propio y no en lo extranjero. Con esto, los límites del concepto de lo político se desbordan; la enemistad con el hermano no puede ser "pura”, ya que todos los afectos están directamente comprometidos. Esta es la enemistad política más intensa: el hermano-enemigo debe ser eliminado a toda costa, en la medida en que es la amenaza más desgarradora a $m i$ forma de vida, pues la conoce de primera mano; el hermano sabe cuáles son mis puntos débiles, sabe cómo se puede destruir la unidad política desde dentro. Es 
así como Derrida declara: “ ¿cómo podría un hermano estar sujeto a la hostilidad absoluta? Va a haber que invertir la hipótesis. Sólo hay hostilidad absoluta para un hermano" (Derrida 1998b, 171). ${ }^{33}$

\section{El hermano-enemigo wayú y la hostilidad absoluta}

La masacre de bahía Portete puede ser leída en términos de la guerra entre hermanos. La inserción de los paramilitares en las redes de parentesco wayú implicó que estos actores armados entraran a formar parte de los apushi, de sus lógicas de lealtades y que conocieran de primera mano las prácticas indígenas. ${ }^{34}$ Esto se tradujo en que los que efectuaron la masacre demostraron tener un conocimiento muy claro de los valores wayús, de tal manera que sabían concretamente qué debían atacar y cómo. En primer lugar, vulneraron el cementerio; para los wayús este espacio es de vital importancia

33 El propio Schmitt se refirió de manera muy breve a la guerra entre hermanos y la definió como la enemistad más absoluta: refiriéndose al caso de Salan, un comandante del ejército francés que se enfrentó con los partisanos argelinos para defender a su nación y que, a causa de ciertas decisiones de guerra que tomó, fue condenado por traición por parte de sus propios "hermanos" franceses, Schmitt afirma que "Salan consideraba al partisano argelino como el enemigo absoluto. De repente, surge a sus espaldas un enemigo mucho peor, mucho más intensivo: el propio gobierno, el propio jefe, el propio hermano [...] El hermano de ayer se reveló como el enemigo más peligroso" (Schmitt 1966, 118).

34 Es preciso señalar que, para los wayú, aquellos que por matrimonio se inserten en las redes de parentesco entran inmediatamente a formar parte de los apushi, es decir, se convierten en familia y como familia se les debe lealtad. Por esta razón, el hecho de que los paramilitares comenzaran a vincularse con las unidades familiares wayús trae consigo lealtades y solidaridades que fueron violadas en el momento en que el grupo armado decidió efectuar la masacre. 
porque allí reposan los ancestros de las unidades familiares, lo cual, además de tener una carga simbólica fuerte, también es la garantía de que la tierra pertenece al apushi. Como bien lo indica el testimonio de un hombre indígena recopilado por Ochoa Sierra en su trabajo de campo, "un wayú prefiere un cementerio a una casa, porque su... el derecho a la tierra está fundamentado alrededor del cementerio. O sea, si tú eres dueño de una tierra, de una zona, sin un cementerio esa zona no es tuya (sic)" (Ochoa 2011,16). El ataque de los paramilitares a los cementerios wayús puede interpretarse como una toma de posesión del territorio; si sabían el significado que tenían estos lugares para la población que allí habitaba, sacar a los muertos de sus tumbas y destruir todos los ornamentos del cementerio es un claro mensaje de deslegitimación de las prácticas wayús y de su posesión del territorio. El daño que esto causó a la comunidad se expresa de manera contundente en el siguiente testimonio: "la profanación de un cementerio es la mayor afrenta que se puede hacer a un clan o familia, que en esta circunstancia se siente herida en lo más profundo de su ser" (Colombia, Centro Nacional de Memoria Histórica 2010, 208).

En segundo lugar, el hecho de que los paramilitares recurrieran a la desaparición forzada como estrategia de terror tampoco es fortuito. Para los wayús, el tratamiento que los cuerpos deben recibir en el momento de su muerte es de gran importancia: si la persona murió naturalmente los rituales son distintos de si murió en virtud de acciones violentas. En el primer caso, las mujeres son las encargadas de hacer la limpieza del cadáver y prepararlo para el funeral; sin este 
paso, el cuerpo no podría ser enterrado, lo que implicaría su no acceso al Jepirra, lugar de descanso de los muertos, ubicado en el Cabo de la Vela. Cuando se trata de una muerte violenta, también son las mujeres las que deben encargarse de la limpieza, pero antes de esto deben cubrir el cuerpo con una manta y no permitir que los hombres lo toquen, ya que esto puede afectar su papel de guerreros, al quebrar su voluntad. En este caso, la limpieza y los preparativos de las mujeres sobre el cádaver garantizan que el hecho violento no vuelva a suceder y que el hombre que murió reciba justicia, ya sea a través de la venganza de sus familiares o de la compensación material. Por esta razón, “[...] la desaparición de Diana y Reina [mujeres lideresas wayuu] desencadena unas consecuencias nefastas puesto que los vivos -familiares de los muertos-, no pueden cumplir ni con los reclamos de justicia por parte de los muertos ni llevar a cabo los rituales que garantizan la no repetición y el tránsito por el camino de los indios muertos a Jepirra [...]" (Colombia, Centro Nacional de Memoria Histórica 2010, 96-97). Así, desaparecer los cuerpos generó parálisis en la comunidad: los cadáveres que no pasen por los rituales prescritos no encuentran paz, y esa intranquilidad, ese no descanso, se transmiten al apushi y quedan grabados en la memoria colectiva hasta el momento en que se encuentren los cuerpos y puedan obtener justicia.

Por último -y esta es quizás la afrenta que mayor peso tuvo para la comunidad wayú en el cuadro de la masacretorturar, mutilar y violar a las mujeres son acciones que no tienen referente alguno dentro de los marcos de guerra 
wayú. ${ }^{35}$ Las mujeres son intocables en las guerras y el hecho de que los paramilitares hayan subvertido esta norma básica representa un golpe decisivo para el pueblo wayú. Sin embargo, es preciso señalar que lo que para la comunidad se vulnera de manera más recalcitrante aquí es la masculinidad de los guerreros wayús. De acuerdo con el informe de Memoria Histórica, el cuerpo de las mujeres wayús se convirtió en un espacio en el que se grababa quién tenía el poder; la vulneración al cuerpo femenino "[...] se torna en mecanismo para establecer la supremacía de los victimarios sobre los hombres Wayuu y específicamente en este caso, de doblegar un modelo de masculinidad de aferrados guerreros, en los que la fortaleza física y emocional y el control del entorno son centrales" (Colombia, Centro Nacional de Memoria Histórica 2010, 100). Entonces, el ataque a las mujeres wayús por parte de los paramilitares tenía como objetivo socavar la figura del guerrero wayú al demostrarle su impotencia para proteger a sus mujeres y al poner en evidencia el poder absoluto que habían conquistado; tan absoluto, que podían disponer del cuerpo de las mujeres, lo cual, en principio, sólo era una facultad legítima de los hombres wayús. ${ }^{36}$

35 Aquí es pertinente resaltar que la violación y tortura a mujeres es una práctica prohibida en el marco de la guerra. Esto no implica que, en la cotidianidad, los casos de violencia contra las mujeres no se presenten. Por el contrario, Guerra Curvelo (2002), por ejemplo, muestra varios ejemplos de cómo se negoció la compensación material o la venganza en situaciones de violencia sexual contra mujeres de determinados .

36 El problema de las relaciones entre los géneros, y en particular, del ataque al cuerpo de las mujeres wayús será de central importancia en las reflexiones del siguiente capítulo. 
Las alianzas entre paramilitares y wayús y la inserción de los primeros en las redes de parentesco de los segundos fueron factores que permitieron el conocimiento por parte de los paramilitares de las prácticas y referentes culturales de la comunidad indígena. Si bien el ataque paramilitar se consideró una traición, en el sentido en que muchos miembros de este cuerpo armado formaban parte de los apushi, por lo cual no se esperaba que generaran tal rompimiento de los códigos culturales wayús, hubo una traición aún más desgarradora que, desde los términos de Derrida, se puede pensar propiamente como la traición de un hermano: José María Barros Ipuana, alias 'Chema Bala', miembro de la unidad familiar wayú de los Ipuana, colaboró en la planeación y ejecución de la masacre, al indicarles con exactitud a los paramilitares a quién debían matar, cómo y los lugares que debían destruir para generar mayor impacto en la población. La familia Ipuana, en su lucha por el monopolio del puerto de bahía Portete, fue una de las que se alió con los paramilitares que se estaban asentando en la región, con el fin de tener un apoyo en armas y en recursos a la hora de reclamar el dominio de los productos del puerto. En virtud de las relaciones de solidaridad que se manejan en los códigos wayús, la familia de Chema Bala respaldó su alianza y contribuyó también en la ejecución de la masacre. Varios testimonios indican que las hermanas de Barros Ipuana "les enseñaban a los arijunas o paramilitares, que era a ellos a los que había que agarrar o gritaba dándole órdenes para que sacara las cosas de la casa de Ocha (sic)" (Colombia, Centro Nacional de Memoria Histórica 2010, 98). Las mujeres wayús que acompañaron a los paramilitares 
en la masacre les iban señalando concretamente a estos actores armados a quién tenían qué matar, cómo debían hacerlo y qué otros mecanismos debían llevar a cabo para que el mensaje de terror fuera más efectivo. Por ejemplo, estas mujeres se acercaban a las casas de las lideresas wayús, les mostraban a los victimarios que allí habitaba la persona a quien tenían que matar y los guíaban en la elección de los lugares donde se le debía dar muerte (se escogieron lugares públicos de gran repercusión para los wayús, como los cementerios o los espacios usualmente destinados para la discusión abierta de cuestiones concernientes al bien de la comunidad).

¿Por qué este accionar de la unidad familiar Ipuana es considerado por los wayús como una traición? Como se ha advertido, la lógica social wayú prescribe que el individuo debe ser leal a los miembros de su apushi; estos son los lazos de solidaridad que se deben entablar. En este sentido, las acciones del clan Ipuana son coherentes con esa lógica de lealtades, pues la familia apoyó a Chema Bala en su decisión de aliarse con los paramilitares para la obtención del puerto. De la misma manera, la estructura social wayú está articulada desde la posibilidad de que se presenten conflictos entre las distintas familias; es viable, entonces, pensar que el ataque de Chema Bala fue un conflicto más entre los que se manifiestan constantemente al interior de los diferentes clanes wayús. No obstante, los testimonios de las víctimas de la masacre señalan recurrentemente que el accionar de Chema Bala y de sus familiares fue una traición al pueblo wayú en general porque no se respetaron sus códigos de guerra, ni los elementos considerados de carácter sagrado para esta comunidad. A pesar 
de que el conflicto es un supuesto central de la organización social wayú, las disputas deben estar reguladas y enmarcadas por los códigos de guerra compartidos por todos los apushi. En virtud de esto, la masacre y sus consecuencias como el desplazamiento forzado o la intimidación a las mujeres, y, con ello, la humillación a los guerreros wayús, son inaceptables para esta comunidad porque trastocan los límites impuestos por las regulaciones a partir de las cuales operan todas las unidades familiares en momentos de disputas.

En términos de Schmitt, se podría decir que lo que se puso en cuestión con la masacre no fueron los intereses de uno o dos apushis, sino la forma de vida wayú, pues se atacaron referentes centrales de lo que, para los wayús, es su estructura social y su forma de ver y estar en el mundo. Un ejemplo de la desestabilización producida por la masacre en la comunidad es la cuestión del territorio. El hecho de que los habitantes de bahía Portete hayan tenido que abandonar el territorio por las vulneraciones sufridas durante la masacre supone la desintegración de los apushi y el desarraigo con respecto a las prácticas de socialización, de trabajo y de vida familiar que se desarrollaban en la cotidianidad. La destrucción de los cementerios, las constantes amenazas en contra de las mujeres y la intimidación generada por los actos de sevicia presenciados en la masacre llevaron a las familias de bahía Portete a abandonar el territorio mientras los paramilitares se apoderaban de él. Tanto la impotencia ante la actuación paramilitar como la perplejidad frente a la manera de operar del enemigo condujeron a los wayús a desplazarse de su lugar de habitación, elemento central en la formación 
y cohesión de los apushi y, en general, de la vida cotidiana wayú. El siguiente testimonio recogido por Ochoa Sierra resulta muy diciente respecto a las implicaciones que tiene el desplazamiento forzado para esta comunidad indígena: "la tierra pa' nosotros es muy sagrada y, por lo menos, ¡salir yo de mi tierra! Eso a mí me afectó mucho, porque es que yo sentía que estaba abandonando... abandonar yo mi tierra es abandonar yo mi madre, abandonar mi abuela, o sea, abandono yo a los míos (sic)" (Ochoa 2011, 86).

De acuerdo con este testimonio, abandonar el territorio fue sinónimo de la renuncia a su forma de vida por varias razones: en primer lugar, las unidades familiares constituidas por parientes uterinos tuvieron que desintegrarse debido a que en los lugares de refugio o de los familiares venezolanos que los hospedaron no podían quedarse tantas personas. En segundo lugar, los hombres tuvieron que buscar trabajos que nunca habían realizado y para los cuales, muchas veces, no estaban capacitados dado que no hablaban español. En tercer lugar, varias mujeres renunciaron a sus roles como lideresas. Y, por último, al abandonar el territorio, los wayús perdieron la autonomía alcanzada con la Constitución de 1991, puesto que, a pesar de que conforme a la ley las prácticas, los códigos culturales y los valores wayús son legítimos y respetados como parte de la nación colombiana, sin territorio, y con ello, sin el lugar a partir del cual se socializa, se practica y se reproduce la vida wayú, no hay autonomía o autogobierno para este pueblo. Los referentes simbólicos (como el hecho de que el Jepirra sea el Cabo de la Vela) y culturales (como las formas de socialización, el 
lenguaje, los roles de cada individuo en la estructura social, la unidad de los apushi, etc.) se fragmentan con la pérdida del territorio. En palabras de Ochoa Sierra, "con el desplazamiento se deterioran aún más sus condiciones de vida; en las mujeres se debilita la autonomía en asuntos como la salud, la alimentación, la producción artesanal y en los hombres se reduce también la capacidad productiva, el poder de control social, territorial y jurídico. De ser soberanos pasan a ser subordinados, vulnerables y dependientes" (Ochoa 2011, 86).

A pesar de que los wayús se definen a sí mismos como un pueblo de guerreros en el que el conflicto es una dimensión ineludible de su existencia, la disputa con los paramilitares trajo consigo consecuencias que desestructuraron sus significados y prácticas básicas. Si bien en el pasado los conflictos entre las diversas unidades familiares suponían frecuentemente el desplazamiento de las familias que perdían la disputa (Desde el desierto 2007, 53), la situación con los paramilitares generó un abandono casi total del territorio y, en particular, una puesta en suspenso de los códigos wayús. En efecto, más allá de la autonomía que tienen los apushi y de las lógicas de solidaridad que funcionan entre ellos, los wayús "como cualquier comunidad son heterogéneos, pero sus usos y costumbres los agrupan en un nosotros" (Ochoa 2011, 85); en otras palabras, aunque las unidades familiares sean autónomas, hay códigos, prácticas y referentes culturales compartidos por los wayús en general. Es así como, en el marco de disputas entre clanes, los códigos de guerra se respetan por las partes enfrentadas y se sabe con precisión, por ejemplo, que las mujeres no se involucran y que los 
cementerios no se tocan. La lucha con los paramilitares desbordó estos límites y atacó lo que es común a los wayús, lo que, independientemente de los conflictos que tengan entre ellos, debe ser defendido y valorado por todos los que dicen pertenecer a esta comunidad.

Desde una perspectiva derrideana, se podría afirmar que sólo un hermano pudo haber trastocado de tal manera las estructuras wayús constitutivas de su identidad y de su concepción de lo valioso para generar consecuencias como el desplazamiento y la pérdida de los referentes culturales considerados más valiosos. Este diagnóstico es compartido por las víctimas de la masacre. En el comunicado redactado tiempo después del acontecimiento se afirma lo siguiente:

[...] desleznable resulta el argumento de las alianzas de nuestros ancestros al que recurren los familiares de Chema Bala para justificar su accionar, pues en el mismo tapete y nivel ponen dichas alianzas con las tejidas por Chema Bala con los paramilitares. Una cosa son las alianzas de nuestros antepasados en guerra justa, para enfrentar al invasor español y otra, son las alianzas de Chema Bala con los paramilitares para masacrar a su propia etnia del pueblo Wayuu y para continuar a manos llenas con el negocio del narcotráfico. [cursiva mía] (Colombia, Centro Nacional de Memoria Histórica 2010, 194)

El rechazo a la comparación entre las alianzas de los ancestros para oponerse al enemigo español con el vínculo entre Chema Bala y los paramilitares resulta revelador: se 
puede pensar que mientras la oposición a los españoles es vista como un accionar para defender la forma de vida wayú, el proceder de la familia Ipuana se presenta como una amenaza directa. Pero lo que se alega en el comunicado no es sólo la amenaza a la forma de vida propia, sino el hecho de que esta proviniera de un wayú. En esto parece radicar la acusación de traición que se plantea frente a Chema Bala: en su carácter de miembro de la comunidad, nunca debió atacar a las unidades familiares con las que tenía disputas por fuera del marco de lo legítimo para el pueblo wayú. Teniendo en cuenta que la alianza entre el clan Ipuana y los paramilitares repercutió en el desplazamiento, en la no posibilidad de reclamar justicia dada la desaparición forzada de los cuerpos y en la violación sexual a las mujeres que se consideran sagradas en el marco de la guerra los wayús acusan a Chema Bala de haber llevado a su propio pueblo al exterminio (Colombia, Centro Nacional de Memoria Histórica 2010,73), al tomar ventaja de su conocimiento inmediato de la estructura social wayú por ser miembro directo de esta. De ahí que, a pesar de que la familia Ipuana haya apelado al sistema judicial indígena como mecanismo para reparar sus afrentas, los wayús hayan optado por rechazar esta petición afirmando que el accionar de este clan trastocó todos los códigos de la comunidad y, en virtud de esto, no hay referentes para juzgarlos y establecer una pena. En palabras del informe de Memoria Histórica, "[...] los miembros de la comunidad dejan claro que la actuación de José María Barros Ipuana alteró profundamente su orden social, económico, cultural, étnico, religioso y jurídico, puesto que los delitos 
que comete son desconocidos 'por nuestros códigos orales y consuetudinario' y, por tanto, transgreden la normatividad que regula las guerras y las disputas entre los Wayuu" (Colombia, Centro Nacional de Memoria Histórica 2010, 73).

Una noción que llama la atención en el comunicado en relación con la conceptualización schmittiana de lo político y con el concepto de hermano en Derrida es la de "guerra justa". Como lo indica Serrano, Schmitt piensa en la "guerra justa” en correspondencia con el concepto de enemigo absoluto: de acuerdo con esto, la guerra justa es aquella en la que cada parte enfrentada "dice defender la verdad y la Justicia” (Serrano 2002, 29). En esta dirección, de la misma manera que las guerras por la humanidad niegan existencialmente al otro de manera absoluta, las guerras que se dicen justas también se sostienen sobre la idea de que la mera existencia del otro es una amenaza sobre la verdad y la justicia universales, por esta razón ese otro debe ser eliminado definitivamente. Así las cosas, el hecho de que los wayús apelen a la noción de guerra justa para definir el accionar de Chema Bala como “injusto” da cuenta de lo que está en juego en el momento de la "traición" del clan Ipuana: lo que se traicionó con la masacre fue lo que para los wayús era la verdad y la justicia, es decir, su forma de vida, sus valores, sus prácticas y sus códigos. Y el hecho de que los ataques estuvieran dirigidos a los elementos que se consideraban representativos de esa verdad y de esa justicia wayús supone la "absolutización” de la enemistad. En palabras de Serrano, "todo grupo que busca defender su identidad, sustentándola en valores absolutos, transforma al otro en 'enemigo 
absoluto', con el que no es posible negociar [...]" (Serrano 2002, 39). ${ }^{37}$ Los paramilitares, y en particular Chema Bala y su unidad familiar, atacaron los valores que se piensan como definitorios de la identidad wayú, como aquellos sin los cuales no puede existir "lo wayuu. En virtud de esto, la enemistad se volvió absoluta: la mera existencia de Chema Bala y de sus aliados paramilitares representa el fratricidio y, con ello, la descomposición y desaparición de la vida wayú.

Lo que la reflexión de Derrida pone de presente frente al caso es que el enemigo absoluto aquí es un hermano. Las víctimas de bahía Portete dividen su historia en dos: antes y después de la masacre. ${ }^{38}$ La traición de Chema Bala y la incursión de los paramilitares en la región representan los puntos de ruptura en la medida en que a partir de estos acontecimientos la estructura social wayú comenzó a fragmentarse; desde Chema Bala, los apushi se tuvieron que dividir y desplazar, las mujeres fueron violadas, los muertos

37 La pérdida de la capacidad de negociación se ve reflejada, por ejemplo, en el cierre a toda posibilidad de conciliación: las víctimas wayús no están dispuestas a conceder prerrogativas al clan Ipuana, y mucho menos a juzgarlos de acuerdo a la normativa jurídica wayú, pues esto implicaría reconocer a Chema Bala y a su familia como enemigos justos.

38 En el informe de Memoria Histórica se apunta que, al relatar los hechos, las víctimas narran el pasado de manera idílica, como si previamente a la llegada de los paramilitares la vida wayú hubiera estado libre de conflictos externos: “[...] la violencia propia se naturaliza, mientras que la externa no, y por eso la masacre se vive como una situación límite de sus vidas en lo personal, a nivel familiar y como comunidad" (Colombia, Centro Nacional de Memoria Histórica 2010, 177). Esto resulta interesante, pues permite advertir cómo las comunidades van grabando ciertos hechos en la memoria colectiva y la traición de Chema Bala, por ejemplo, se nombra de manera enfática y se ubica como el punto de ruptura entre esa vida armónica y la situación de fragmentación que se vive hoy en día. 
desenterrados y los cadáveres desaparecidos. Y digo "desde Chema Bala” porque, para las víctimas, además de que los paramilitares se familiarizaron con la vida wayú desde sus matrimonios y alianzas con unidades familiares, la información que el clan Ipuana aportó para llevar a cabo la masacre fue crucial: en la medida en que esta familia era wayú, su conocimiento de los códigos, de los referentes culturales y de los valores de esta comunidad indígena era directo, por esto sabían concretamente qué debían atacar para lograr el desplazamiento y la rendición de los wayús. No es fortuito que las hermanas de Chema Bala les fueran indicando con precisión a los paramilitares cabezas de la masacre a quién debían matar, las casas a las que debían irrumpir y la forma como debían hacerlo. Entonces, diría Derrida que el enemigo absoluto encarnado en el hermano es aún más absoluto porque no hay quien pueda poner en cuestión el orden de manera tan radical como lo hace el hermano: es él quien me conoce de primera mano, es mi gemelo (Derrida 1998b, 171), tenemos el mismo origen, la misma forma de vida, por esta razón, cuando el hermano se convierte en enemigo, el orden corre más riesgo de ser fragmentado y eliminado, pues sólo el hermano sabe con precisión qué atacar y cómo.

Derrida escribe: “‘ ‘a quién puedo finalmente reconocer como mi enemigo?'. Respuesta: 'manifiestamente, sólo a aquel que puede ponerme en cuestión. En cuanto lo reconozco como mi enemigo, reconozco que puede ponerme en cuestión. ¿Y quién puede efectivamente ponerme en cuestión? Sólo yo mismo. O mi hermano" (Derrida 1998b, 187). Cuando el conflicto se da entre unidades políticas soberanas 
(tal y como lo describe y prescribe Schmitt), hay un enemigo verdadero que pone en cuestión la propia forma de vida; sin embargo, en este caso, existen regulaciones sobre la guerra, sobre qué puede ser atacado y qué no. Con un enemigo verdadero se pueden establecer treguas y negociaciones; aquí se puede dialogar con el otro sobre los términos para llevar a cabo el enfrentamiento. En contraposición, con el enemigo absoluto no se negocia: con el enemigo absoluto se entabla una guerra sin retroceso, en la que el otro tiene que ser eliminado por mor a la conservación propia. En esto radica el hecho de que este hermano-enemigo "ponga en cuestión” el orden de manera absoluta: en la medida en que el vínculo de hermandad trae consigo familiaridad, proximidad, hogar (Derrida 1998b, 188), el hermano representa lo que es la unidad política, es decir, lo que la dota de cohesión; los valores, las prácticas y los referentes que son comunes y compartidos por todos los miembros de la comunidad y que los unen alrededor de una misma forma de vida. Es por esto que, en el momento en que el hermano se presenta como una amenaza para la existencia del orden, lo pone en cuestión absolutamente, pues rompe con la unidad que se supone, debe defender como propia; el hermano-enemigo es la diferencia dentro de ese mundo de iguales vinculados por la fraternidad y esa diferencia quiebra el orden desde dentro. No se trata de una amenaza externa frente a una comunidad unificada y cohesionada, sino de una amenaza interna que fragmenta internamente. Por ello, si el hermano-enemigo no se elimina, la unidad política se extingue. De ahí que la guerra interna, la guerra con el hermano, en lugar de negar 
lo político al romper sus acotaciones, en realidad alberga una “hiperpolitización” (Derrida 1998b, 152), debido a que el conflicto, el antagonismo y la hostilidad se radicalizan, hasta el punto de negar absolutamente al propio hermano en favor del mantenimiento de la unidad política. Así, para Derrida, lo político en su sentido más acuciante está allí donde Schmitt encontraba una negación de lo político: lo que amenaza de manera más intensa la forma de vida propia, lo que lleva las lógicas de la hostilidad propias del conflicto a su nivel más absoluto es el hermano-enemigo porque fragmenta a la comunidad desde su interior. ${ }^{39}$

\section{La desnaturalización del hermano}

Además de postular al concepto de hermandad como parte integrante (y a la vez desintegrante) del concepto de lo político, ${ }^{40}$ Derrida indaga sobre la manera como se consti-

39 Derrida ha dicho que su forma de hacer filosofía parte de identificar la condición de posibilidad de un fenómeno como su condición de imposibilidad (Derrida 1998a, 159). Este movimiento parece efectuarse a propósito del concepto de lo político de Schmitt: si la condición de posibilidad de lo político es la existencia de una unidad política representada por el Estado soberano, esto también es su condición de imposibilidad en la medida en que la figura del hermanoenemigo pone de presente que la unidad política como condición de posibilidad del concepto alberga en síla posibilidad de su destrucción, de su fragmentación.

40 Integrante porque el concepto de hermano-enemigo está inmerso en las lógicas propias del conflicto y la hostilidad; el hermano "fratricida" -como lo denomina Derrida- surge en lo político mismo y no por factores externos a él: surge de la traición al modo de vida propio y de la amenaza al orden que, en su calidad de "hermano", debería ser defendido y no atacado. Pero, del mismo modo que es un concepto integrante de lo político, también es desintegrante porque, si se piensa en lo político tal y como Schmitt lo hacía, en virtud del mantenimiento de la unidad política soberana, el hermano constituye la amenaza más radical a esta unidad. 
tuye el lazo de fraternización entre los hermanos de la misma comunidad política. Usualmente, dice Derrida, hablar de hermandad implica referirse a una unión natural: se es hermano de alguien en tanto se comparte la misma madre, el mismo origen; como bien lo indica el Lisis, el hermano es hermano por naturaleza (Platón 1985, 314). Bajo esta perspectiva, la hermandad se funda en "[...] la homogeneidad, en la homofilia, en una afinidad sólida y firme, puesto que nacida del co-nacimiento, de la comunidad natal. Y este parentezo alimenta una amistad constante y homófila no sólo en palabra sino, de hecho, en acto" (Derrida 1998b, 113). La cohesión de la unidad política estaría dada, entonces, por ese lazo natural entre los hermanos, por ese origen común que supone la homogeneidad, la igualdad entre todos los miembros de la comunidad. Para Derrida, esta manera de pensar en el hermano como un concepto directamente relacionado con la naturaleza resulta sumamente problemática, pues esa "naturalización” de la fraternización esconde el carácter contingente e histórico inherente a la formación de la hermandad. Ser hermano es una convención, es un constructo social.

En este sentido, la filosofía de Derrida comparte con el pragmatismo de Rorty la idea según la cual las posturas fundacionalistas en filosofía se equivocan al atribuirle al mundo humano la existencia de "[...] un poder ahistórico que tiende a lo justo, un poder llamado verdad o racionalidad [...]" (Rorty 1998a, 126) que descansa en la naturaleza humana. Efectivamente, en el momento en que la hermandad se define en virtud de estos poderes que se muestran como ahistóricos 
y como definitorios absolutos de lo que es la verdad y la justicia, estamos en el campo de la enemistad absoluta y, con ello, de la escalada de la violencia, pues el otro se piensa como un contradictor de valores universales y naturales, como una amenaza al orden y como susceptible de ser eliminado por todos los medios posibles. Rorty enfatiza que la articulación de una comunidad de un "nosotros" en contraposición a un "ellos" no es producto de una naturaleza humana inalienable o de unos valores de cáracter universal; cuando la cohesión del "nosotros" se piensa de esa manera, el "ellos" se concibe como un grupo de individuos "seudo-humanos" o como un conjunto particularmente malo de humanos, en razón de que no se acogen a los valores supuestamente válidos universalmente y por naturaleza (Rorty 1998a, 129). En este campo de "lo natural" no hay diálogo posible con el otro que es diferente, porque no se reconoce que los valores que vinculan al "nosotros" son contingentes, es decir, son producto de contextos históricos precisos que pueden cambiar y renegociarse, y por ello, la diferencia es vista como desviación que debe ser rectificada.

De esta manera, la naturalización del hermano genera una naturalización de la unidad política, ya que se presume que todos los integrantes de una comunidad de hermanos deben compartir los mismos valores sustentados sobre "lo natural" o sobre identidades articuladas como esenciales o fundadas en fuerzas que trascienden lo histórico y se asume que esos valores naturales y universalmente compartidos son las condiciones de posibilidad para la existencia de la 
unidad. ${ }^{41}$ No obstante, de acuerdo con Derrida, las unidades políticas, a diferencia de lo que diría Schmitt, no son cerradas, no son homogéneas en su interior; por el contrario, albergan diferencias, es decir, no son “puras”, sino que están inmersas en procesos de negociación y de redefinición constantes. En esta dirección, el concepto de hermano-enemigo pone de manifiesto ese punto de quiebre en la unidad política que se piensa como homogénea, o, en los términos de Derrida, el hermano amenazante de su propia forma de vida da cuenta de la "heterogeneidad originaria" (Derrida 1998b, 128) de todo grupo humano. Nuevamente, Derrida apunta aquí a señalar lo irreductible al concepto, lo que escapa a todo intento de homogenización; se puede decir que, con base en el concepto de hermano-enemigo, es posible pensar en la unidad política en términos de la diferencia, es decir, en términos de lo que cuestiona la homogeneidad supuestamente natural de la comunidad. Como bien lo advierte Beardsworth, en la filosofía de Derrida, es preciso "[...] trazarse una distinción entre una comunidad política y lo que necesariamente excede a esa comunidad, o lo que queda afuera del cálculo de ella, en el proceso de auto-formación”, y se añade que una filosofía política de este tipo "[...] demanda un pensamiento

41 A este respecto, Derrida se refiere a lo problemáticos que resultan los nacionalismos sustentados sobre la idea de "hermandad natural", puesto que, para él, estos se encuentran directamente relacionados con la xenofobia y el etnocentrismo, y, en últimas, con la idea de que, en virtud de que cada comunidad está constituida sobre lazos "naturales" y esenciales, todo grupo humano que no se acomode a estos no es natural y hay que eliminarlo para mantener la "pureza" de la unidad política (Derrida 1998b, 121). 
de la comunidad política que tome en serio el tiempo y las diferencias" (Beardsworth 2008, 18).

Pero ¿qué significa "tomar en serio el tiempo y las diferencias"? En primer lugar, reconocer que la unidad política no es una entidad homogénea, conduce a la desnaturalización de la hermandad o, en últimas, a dejar de ver los lazos que vinculan a las comunidades como naturales e innegociables, para concebirlos como históricamente constituidos. En segundo lugar, una filosofía política de la diferencia de corte derrideano también pretende poner a prueba los conceptos de la filosofía en la realidad misma, esto es, en las dinámicas vividas por los grupos humanos reales. Este objetivo no dista mucho de lo que el Schmitt en cuanto teórico del conflicto se proponía con el concepto de lo político: en efecto, al articular una definición de lo propiamente político, Schmitt planteó a la díada amigo-enemigo como un criterio susceptible de ser contrastado con la práctica. En este sentido, Derrida sigue esta misma operación, pero con el fin no de mantener a la unidad política a toda costa, sino de examinar los procesos que se llevan a cabo para su constitución y las realidades que deja de lado al fundarse como unidad homogénea. Puesto en otros términos, la reflexión de Derrida apunta a utilizar el concepto de lo político como una herramienta para pensar el mundo contemporáneo. Por esta razón, el concepto debe ser sensible ante los diferentes tipos de conflictos que son inherentes a las configuraciones actuales y reales de amigos y enemigos que, en ocasiones, por el ánimo de mantener la "pureza conceptual", se ignoran, a pesar de que forman parte de las lógicas de lo político. 
Por último, a la pretensión de tomar en serio las diferencias subyace un compromiso con la emancipación, la reducción de la violencia y, sobre todo, con la democracia (Derrida 1998a, 160; 1998b, 126). Según Derrida, una democracia no puede estar fundamentada en la homogeneidad o en la naturalidad, pues esto repercute en la invisibilización y silenciamiento de lo que no se ajusta a la norma dictada por naturaleza. Por esta razón, Derrida aboga por “[...] pensar y vivir una política, una amistad, una justicia que comiencen por romper con su naturalidad o su homogeneidad, con su supuesto lugar de origen. Que comiencen, pues, allí donde el comienzo (se) divide y difiere. Que comiencen por marcar una heterogeneidad 'originaria'” (Derrida 1998b, 128). Si se reconoce la diferencia o heterogeneidad inseparables de todo orden social, la enemistad absoluta, en la que el otro es visto como una amenaza susceptible de ser eliminada definitivamente, no será la regla. En palabras de Laclau, el reconocimiento de la contingencia constitutiva del mundo humano supone pensar en todo orden como provisional y como sujeto a negociación (Laclau, 1998); a pesar de que, siguiendo a Schmitt, el conflicto sea una dimensión definitoria de lo humano, es preciso saber que las identidades configuradas en virtud de la oposición "amigo/enemigo" no son naturales ni ahistóricas. Pensarlas así sólo aumentará la hostilidad, supondrá la escalación de la violencia y no permitirá que las realidades diferentes se introduzcan en el campo de lo político y entren a negociar o a participar en él.

Bajo esta óptica, además de que el concepto de hermanoenemigo es útil para Derrida, ya que pone en evidencia los 
puntos de quiebre de la unidad política entendida como un orden homogéneo y natural, también es un concepto que enriquece la discusión sobre lo político en tanto que da cuenta de la manera como se construyen y naturalizan las identidades como parte del funcionamiento de órdenes concretos y de configuraciones de formas de vida determinadas, y el modo en que esto conduce al aumento de la violencia. Si se atiende al caso de bahía Portete es posible advertir que el extremismo de la violencia de la masacre radica, no tanto en el hecho de que, siguiendo a Schmitt, fue parte de un conflicto irregular con rasgos de partisanismo, sino en que lo que se puso en el centro de la disputa fue el mantenimiento o la extinción de la forma de vida wayú. Lo que se consideraba central para la existencia wayú se puso en cuestión en el momento en que Chema Bala y su familia les señalaron concretamente a los paramilitares qué debían atacar y cómo. Entonces, plantear el concepto de hermano-enemigo como una clave de lectura para el caso permite examinar la manera como los wayús se definen a sí mismos, al igual que es posible hacerse una idea de por qué este grupo indígena divide su historia en dos desde la traición de Chema Bala, es decir, de las razones por las cuales la masacre representó la fragmentación de la comunidad y de los valores que la cohesionaban.

Efectivamente, se puede afirmar que el concepto de enemigo es fructífero en la reflexión sobre lo político en virtud de que, a partir de él, se pueden estudiar las lógicas vinculadas con la formación de las identidades o de las formas de vida; parecería que el enemigo dice más de mí mismo que de él mismo, en el sentido de que, en el momento en que ese otro 
me pone en cuestión, $m i$ forma de vida se hace explícita. La traición de Chema Bala puso de manifiesto, entonces, lo que era concebido como definitorio de la forma de vida wayú y su ataque implicó su puesta en cuestión y su rompimiento. Pero además de ser útil en este caso para advertir la manera como el hermano pone en jaque la forma de vida wayú, que a la vez se hace explícita en este proceso, el concepto de hermano-enemigo también resulta provechoso para pensar en la diferencia, en cómo los wayús no son una comunidad cerrada alrededor de una identidad unívoca e inmutable. El hecho de que se entablaran alianzas con los paramilitares y de que, en general, a lo largo de su historia este pueblo haya tenido que modificar sus prácticas como consecuencia de las relaciones entabladas con otros grupos ${ }^{42}$ evidencia la no naturalidad del orden, su contingencia, su articulación históricamente constituida.

Así las cosas, la reflexión de Derrida sirve al caso en tanto que complejiza la lectura de Schmitt, al mostrar que para el

42 Tal es el caso, por ejemplo, de la figura del “corredor wayú”. Este oficio, generalmente practicado por mujeres, tiene como objetivo mediar entre el mundo wayú y el mundo no wayú (Guerra 2002, 94); para ser corredor, se requiere el aprendizaje de otros idiomas y el manejo de buenas relaciones interpersonales. Esta figura fue apareciendo a medida que el contacto con otros pueblos fue desarrollándose. Otro ejemplo de cómo la forma de vida se renegocia a partir del contacto con los otros es el modo en que las actividades económicas de tipo occidental se convirtieron en símbolos de estatus y poder en la comunidad wayú; según Guerra Curvelo, el narcotráfico y el contrabando principalmente son fenómenos que “[...] se proyectan en el escenario social y económico de la península [de la Guajira] promoviendo el surgimiento de nuevos modelos de riqueza basados en estas actividades y estimulando procesos de jerarquización social dentro de la comunidad Wayuu” (Guerra 2002, 93). 
estudio sobre lo político es central preguntarse por el modo a partir del cual se construye y se piensa en la unidad política, en esa comunidad de hermanos vinculados por lazos de fraternización. Y, como parte de esta indagación, se logra advertir que la unidad política no es una entidad homogénea, cerrada y ajena a los procesos históricos; por el contrario, alberga diferencias y realidades que no forman parte de lo que se ha instituido como el orden a seguir, pero que son cruciales a la hora de entender las lógicas mismas de constitución de comunidad. De ahí que si el concepto de lo político de Schmitt resulta provechoso para pensar las realidades concretas en las que la díada amigo/enemigo opera, es preciso que sea sensible a los diferentes tipos de enemistad y a la manera como la amistad se forma, en este caso, a través de la figura del hermano. Para el Schmitt reduccionista que define lo político en términos del mantenimiento de la unidad política soberana y en contra de cualquier tipo de enemigo interno que pueda fragmentarla, el hermano-enemigo es sinónimo de despolitización, pues esta figura alberga la extinción de la unidad política. En contraposición, el Schmitt pensador del conflicto y de la diferencia vería en el hermano-enemigo una forma de enemistad que habría que examinar, con el fin de determinar su relevancia frente al concepto de lo político. Justamente, lo que se ha intentado en este capítulo es mostrar, a partir de las reflexiones de Derrida en relación con el caso, que el concepto de lo político vinculado con una noción de unidad política ahistórica y homogénea resulta problemático e infructuoso en el momento de atender al conflicto que se desarrolló en bahía Portete. 


\section{Conclusiones: el concepto de hermano-enemigo y sus potencialidades para pensar el conflicto en bahía Portete}

El concepto de hermano-enemigo desarrollado en el capítulo anterior da cuenta de lo complejo que es el caso de bahía Portete principalmente en tres sentidos: en primer lugar, siguiendo las reflexiones de Derrida, la noción de hermano supone pensar en la unidad política en términos de la diferencia. En la conceptualización schmittiana la homogeneidad se presenta como la condición de posibilidad de la unidad política, en virtud de esto se sostiene que las diferencias internas fragmentan y acaban con la forma de vida propia. Por esta razón, se afirmaba que el Schmitt reduccionista concebía al enemigo interno como susceptible de ser eliminado a toda costa, en pro del mantenimiento de la unidad soberana e inquebrantable, y con esta mirada se olvidaba la reflexión y el cuestionamiento de la unidad política misma, de cómo se conforma, de cuáles son sus contradicciones y sus desarmonías, y de cómo estas generan nuevos tipos de enemistades que un análisis de lo político definido desde el conflicto no puede pasar por alto. Así las cosas, la propuesta de Derrida invita a pensar los conflictos, las rupturas y las contradicciones de la unidad política como parte de lo político mismo y conlleva a la articulación de un concepto de lo político que funcione como herramienta para entender los conflictos reales del mundo contemporáneo, conflictos que, valga decir, están cargados de complejidades internas que no se reducen al marco de comunidades homogéneas y armónicas enemistadas con grupos extranjeros igualmente 
homogéneos y armónicos. El concepto de hermano-enemigo rompe, entonces, con el reduccionismo de Schmitt, al mostrar que las unidades políticas albergan diferencias internas que rebasan cualquier intento de unificación. Es justamente por esta razón que el hermano resulta una categoría útil frente a las demandas del caso de bahía Portete: allí se trata de un conflicto en el que la aparición del enemigo interno fue la coyuntura precisa para que la comunidad se pusiera en cuestión y para que la violencia aumentara considerablemente. El concepto de lo político debe ser sensible a este enemigo interno si se pretende que funcione como herramienta para pensar el caso desde el lenguaje de la enemistad y el conflicto.

En segundo lugar, además de cuestionar la supuesta homogeneidad de las unidades políticas, el concepto de hermano-enemigo también trae consigo la idea según la cual el lazo de "hermandad", que se muestra como el factor cohesionador y unificador de las comunidades alrededor de la defensa de una forma de vida propia, no es natural, sino históricamente constituido. En efecto, para Derrida, la noción de hermano suele conducir casi implícitamente a la noción de "lo natural": se es hermano de sangre, se es hermano por naturaleza, por nacimiento. Este supuesto lleva a la naturalización de las unidades políticas, y con ello, al aumento de la violencia, pues cada grupo humano dice defender los valores y prácticas cuya validez y legitimidad recaen en su carácter natural. Bajo esta lógica, el otro con forma de vida diferente se percibe como un enemigo de lo natural y, por esto, como un enemigo que debe ser eliminado completamente. Lo que Derrida intenta poner de presente a 
través del concepto de hermano-enemigo es que un análisis de lo político que tenga como base un compromiso con la comprensión de los conflictos y las violencias contemporáneas, $y$, sobre todo, con la democracia y la reducción de la violencia, debe partir, por un lado, del reconocimiento de que esa idea de los órdenes fundados en la naturaleza opera en la formación efectiva de los grupos humanos y tiene consecuencias precisas sobre la manera como se desarrollan los conflictos, y por otro lado, de que dicho reconocimiento viene acompañado por la tarea del filósofo de cuestionar esa supuesta naturalidad de las identidades, con el fin de entender los procesos que operan en su configuración e identificar los problemas que acarrea (como la reproducción de prácticas de violencia y sevicia, por ejemplo). En relación con el caso, la desnaturalización de las identidades permite percibir el modo en que el surgimiento del enemigo interno fue producto de una serie de procesos sociales que llevaron al aumento de la tensión entre los diversos clanes wayús, y finalmente, al ataque a los valores y prácticas que históricamente se han considerado como las bases de la identidad de ese grupo indígena. Puesto en otros términos, el hermanoenemigo de los wayús se gestó históricamente y como parte de procesos sociales, de contacto con otros grupos y prácticas, en los que la propia comunidad estaba inmersa.

En tercer lugar, el concepto de hermano-enemigo viene acompañado del de “irreductibilidad”. Como se señaló anteriormente, según Derrida, la realidad es incapturable en conceptos y cualquier orden conceptual siempre dejará escapar algún fenómeno. El ejercicio filosófico, de acuerdo 
con esto, no se define por el mantenimiento de la pureza conceptual, es decir, por la defensa ciega del concepto frente a las realidades que lo ponen a prueba, sino por la manera como estas enriquecen, modifican o llevan a la disolución del orden conceptual y a la articulación de otro que responda de manera más acertada a los requerimientos que la realidad misma impone. En otras palabras, la idea es que el concepto sirva como herramienta para pensar los fenómenos reales, y en esta dirección, la realidad exige al concepto, lo pone a prueba y le demanda pensar sus límites. El hermano-enemigo da cuenta de esta irreductibilidad de la realidad al concepto, en la medida en que a partir de esta noción Derrida pone a prueba a la teoría schmittiana, al mostrar cómo la aparición del enemigo interno, en lugar de negar o contradecir el concepto de lo político, en realidad alberga un tipo de enemistad absoluta cuyo carácter es preciso considerar en el marco de una conceptualización del conflicto. El caso de bahía Portete es enriquecedor a este respecto en tanto que le exige al concepto de lo político de Schmitt la introducción de nuevos elementos y matices sin los cuales no es posible la comprensión. El matiz que se consideró en este capítulo fue el del enemigo interno o el hermano: un análisis reduccionista de lo político no sería sensible a la aparición de la figura de Chema Bala y de su alianza con los paramilitares, pues se limitaría a pensar estos fenómenos como la incapacidad del Estado colombiano para unificarse en su interior y para ser soberano. Esta interpretación desconoce los procesos sociales, políticos y económicos que se pusieron en juego en el momento de la masacre y que fueron cruciales para el surgimiento 
del conflicto entre los wayús y los paramilitares y para la configuración de la enemistad. Por esta razón, el concepto de lo político pierde su capacidad para ponerse a prueba y repensarse a partir de la reflexión sobre los conflictos reales. Para Derrida, el juego entre lo político y la irreductibilidad es lo que permite la apertura del concepto, lo que recupera su sensibilidad frente a los retos que imponen las situaciones concretas vividas por grupos sociales particulares. Desde esta perspectiva es que el caso de bahía Portete entra a dialogar con la conceptualización de lo político.

Siguiendo las lógicas de la irreductibilidad y su relación con el concepto de lo político, en el próximo capítulo se abordará una realidad del caso de bahía Portete que parecería exigirle a la teoría del conflicto de Schmitt la apertura a nuevas perspectivas y la introducción de nuevas herramientas para entender el tipo de enemistad que allí se gestó: las mujeres wayús se presentaron ante los enemigos paramilitares como sus enemigas, en tanto que ellas se opusieron a ellos constantemente y llevaron a cabo diversas actividades de resistencia frente a su accionar. La inquietud que guiará las reflexiones que siguen se puede formular así: si tanto mujeres como hombres wayús se mostraron abiertamente como enemigas y enemigos de los paramilitares, ¿por qué estos actores armados recurrieron a la amenaza y la tortura sexual como estrategia de intimidación sobre el cuerpo femenino y no utilizaron estas mismas armas en contra de los hombres? ¿En qué radica la diferencia? Y, más aún, ¿es relevante plantear dicha distinción en el marco del concepto de lo político y de la noción de enemistad? Lo que se examinará a continuación 
es si estas cuestiones tienen sentido y son pertinentes en el contexto del lenguaje schmittiano alrededor del cual se ha estudiado el caso. Si esto es así, tendríamos, entonces, otra diferencia (la diferencia sexual) que, desde el reduccionismo, podría fragmentar aún más lo político, pero que, al apelar al teórico del conflicto que es Schmitt, se tendría que estudiar y problematizar para dar cuenta de la manera como se configuró la enemistad en el caso de bahía Portete. Esto último será sugerido como un terreno provechoso para desarrollar en futuras investigaciones. 



\section{Capítulo III \\ Hermanos y hermanas wayús: la diferencia sexual y el concepto de lo político}

A través del concepto de hermano-enemigo, Derrida le puso retos a la conceptualización de Schmitt: si el concepto de lo político se pensó como un criterio que proporciona claves de lectura y herramientas para entender los diferentes conflictos entre grupos humanos, el enemigo interno que surgió en el caso de bahía Portete no puede ser ignorado. Más bien, el hermano-enemigo debe ser estudiado como parte de las lógicas del conflicto porque, de lo contrario, la complejidad de la disputa no lograría ser capturada y el concepto de lo político se volvería inútil ante el entendimiento de los conflictos reales, ya que no podría ser sensible frente a sus particularidades y matices. En el caso de bahía Portete, el concepto de hermano fue provechoso para mostrar los lazos de fraternidad, históricamente constituidos, que dotan de cohesión a la unidad política y que, al romperse por la traición del hermano, ponen en cuestión la existencia de la forma de vida propia de manera absoluta. Con base en esto, Derrida parece plantear otro reto cuyo sentido no es explicado: “¿Y la hermana? ¿Estará en el mismo caso? ¿Será un caso de fraternidad?” (Derrida 1998b, 172). 
En el presente capítulo se defenderá que la pregunta de Derrida por la hermana es central en el momento de entender el carácter del conflicto que se desarrolló en bahía Portete. La introducción de la figura de la hermana en la discusión sobre lo político tiene dos consecuencias: en primer lugar, supone ubicar a la diferencia sexual en el centro de las lógicas del conflicto, al mostrar que las diferencias entre hombres y mujeres tienen impacto sobre el modo en que se define la disputa. En segundo lugar, en el caso de bahía Portete, esa diferencia entre hombres y mujeres se manifiesta por la distinción en los métodos de intimidación usados para acabar con enemigas y enemigos. Por esta razón, la introducción de la diferencia sexual en ese conflicto descansa sobre el examen de las estrategias usadas para dar muerte al enemigo y a la enemiga. En este sentido, si se pretende dar cuenta de los matices y complejidades de la disputa de bahía Portete no se puede pasar por alto el hecho de que los métodos de intimidación aplicados a enemigos y enemigas fueron diferentes y esto repercutió en el carácter que adquirió el conflicto. La centralidad de la noción de diferencia sexual sintetizada en la figura de la hermana radica, entonces, en que le exige a Schmitt pensar en lo político con sexo, es decir, advertir que las diferencias socialmente articuladas entre hombres y mujeres son cruciales a la hora de definir y reconocer al otro-enemigo. De ahí la pertinencia de proponer un concepto como el de "hermana" para entender lo político desde la diferencia sexual. 


\section{Las mujeres wayús: enemigas de los paramilitares}

Guerra Curvelo afirma que "las mujeres Wayuu pueden desempeñar un papel importante en el desarrollo de las disputas en que se ve envuelto un grupo familiar" (Guerra, 2002, 121). A pesar de que la potestad sobre las decisiones recae en las autoridades tradicionales encabezadas por hombres, las mujeres suelen tener gran influencia en el curso de los hechos en momentos de conflicto. En efecto, en el marco de las guerras, las mujeres "[...] usualmente dan consejos a sus parientes varones, ayudan a movilizar apoyo, contribuyen con sus bienes al pago de las compensaciones y algunas pueden hablar muy fuerte durante las negociaciones" (Guerra 2002, 121), de la misma manera como pueden asumir roles de espías y garantizarle a su apushi un conocimiento detallado sobre los "puntos débiles" del enemigo. Estos papeles que las mujeres desempeñan en los conflictos no son producto de la arbitrariedad; por el contrario, descansan sobre las actividades sociales que usualmente se asignan a lo femenino en la estructura wayú. El antropólogo Alessandro Mancuso (2006) estudia las relaciones de género entre los wayús y dedica especial atención a los roles asumidos por las mujeres en diferentes áreas de la vida social. Particularmente, enfatiza en el hecho de que el liderazgo de algunas mujeres wayús en relación con asuntos políticos y de guerra se explica por los espacios que ellas manejan en la vida diaria y que son, en su mayoría, vetados para los hombres. En virtud de esta división de roles, las mujeres han adquirido habilidades específicas para interactuar constantemente con otros grupos 
y para desenvolverse en diversas áreas relacionadas con los intereses de los clanes o de la comunidad en general.

Uno de los espacios que usualmente se ha definido por ser estrictamente femenino en la comunidad wayú es el del comercio. De acuerdo con Mancuso, "[...] el comercio es considerado sobre todo una actividad femenina, no sólo porque los hombres por lo general se encuentran ocupados en otras actividades, sino también porque las mujeres tienen la reputación de ser más cuidadosas y 'responsables' en el manejo del dinero" (Mancuso 2006). Las mujeres wayús, al intercambiar productos tanto hechos por hombres como elaborados por ellas mismas (como en el caso de las mochilas), han entablado relaciones con sectores del mundo no indígena (con arijunas), con los que mantienen un intercambio constante como parte de los arreglos comerciales. En este contexto, las mujeres wayús se han caracterizado por tener habilidades en el manejo de la palabra, en el aprendizaje de otros idiomas y en el conocimiento de los otros grupos sociales con quienes hacen negocios. Es por esto que se ha afirmado que uno de los roles centrales asignado a lo femenino en el mundo social wayú es el de "intermediación", esto es, el papel de comunicarse, interactuar y negociar con el mundo "no indígena".

Pero esta "función de frontera", como la ha llamado Ochoa Sierra (Ochoa, 2011, 25), no se restringe al comercio: las mujeres también son fundamentales en el momento de interacción entre el mundo de los vivos y el de los muertos. Siguiendo el informe de Memoria Histórica, "ellas también, en su papel de chamanes y encargadas de enterrar a los muertos 
son las que se comunican con el mundo de los espíritus" (Colombia, Centro Nacional de Memoria Histórica 2010, 92); ellas son las encargadas de realizar los ritos adecuados para que el espíritu, y con él, su línea familiar, puedan descansar en paz. Sin esta intervención de la mujer wayú no es posible que el espíritu del muerto pueda seguir su curso hacia el Jepirra; y es la mujer y no el hombre quien asume esa función, porque el hombre es un guerrero y el contacto con los muertos recae en la pérdida de su voluntad y tenacidad a la hora de cobrar venganza o de prepararse para una guerra. De acuerdo con Mancuso, la identificación de la mujer con la función de frontera entre el mundo de los vivos y de los muertos descansa en una concepción de lo femenino que lo vincula con aquello que representa la paz y lo sagrado. El hecho de que sean las mujeres, y no los hombres-guerreros, las que tocan a los muertos y hacen los rituales correspondientes al descanso de los espíritus lleva a pensar en lo femenino como lo que trae paz y armonía, en oposición al mundo masculino, que es el de la guerra y el conflicto. De igual manera, para Mancuso, esta asociación entre mujer y paz o descanso de los muertos también supone concebir a las mujeres en términos de lo sagrado, en la medida en que sólo ellas tienen acceso a espacios que no pueden ser contaminados con el mundo de la guerra encabezado por los hombres.

La función de frontera remite, entonces, tanto a las mujeres mediadoras entre el mundo wayú y los arijunas con quienes se comercia, como al contacto que ellas establecen entre el mundo de los vivos y el de los muertos. El punto clave aquí es el de la intermediación: las mujeres wayús son 
intermediarias, cumplen papeles de comunicación y de interacción con otros espacios y grupos sociales. De ahí que Ochoa Sierra apele al término "frontera": las mujeres tienen la capacidad para moverse, interactuar y negociar con otros mundos; ellas pueden ubicarse en el límite entre el mundo wayú y el mundo arijuna o el mundo de los espíritus y entablar relaciones desde allí. Mancuso y Ochoa Sierra coinciden en afirmar que, en las últimas décadas, la función de frontera que, en principio, se restringía al comercio y al mundo de los espíritus, se ha ampliado a tal punto que las mujeres han adquirido habilidades en la resolución de disputas interétnicas y, en general, de conflictos que ponen en riesgo tanto a los apushi concretos como a la comunidad wayú en general. Las destrezas ganadas en el campo de la intermediación con otros mundos han sido aplicadas en diferentes ámbitos y han llevado a las mujeres a adquirir potestad sobre asuntos políticos y públicos. El dominio de lenguas extranjeras, las fuertes habilidades en el manejo de relaciones interpersonales con grupos externos y el desarrollo de las capacidades de negociación son algunos de los atributos que dotan a las mujeres de un estatus especial para resolver conflictos políticos. Como bien lo indica Ochoa Sierra, "las mujeres wayús a diferencia de muchas mujeres occidentales, son quienes más estudian, quienes tienen mayor contacto con la economía externa, saben de ello y manejan dinero. Tienen poder de circulación en espacios masculinos de arijunas [...] lo que hace que no se perciban como desvalidas, en especial aquellas con alto estatus social” (Ochoa 2011,28). 
Sin embargo, el liderazgo logrado por algunas mujeres wayús como parte de su papel de intermediarias tiene un carácter ambiguo. Según Mancuso, "el líder se presenta como la persona que va a 'hablar' con los alijuna, con los 'criollos' e intenta 'lograr cosas' a través de ellos” (Mancuso 2006), pero esto no implica pensar en la posición de liderazgo en términos de poder o autoridad: el líder no es el jefe. En este sentido, el líder se muestra ante los enemigos de la disputa, es visible públicamente ante ellos, pero las decisiones últimas recaen en el papel del jefe. El líder es justamente un intermediario. La ambigüedad de este papel radica, entonces, en el hecho de que, por un lado, el líder es el que se presenta públicamente ante el enemigo, el que lo enfrenta, el que negocia con él, y, no obstante, por otro lado, el líder no toma las decisiones importantes con respecto al conflicto, aunque puede generar influencia en él por medio del uso de la palabra, de la transmisión de información y del conocimiento detallado del enemigo. Así, el líder se muestra como el enemigo directo frente a los otros, pero él no toma las decisiones fundamentales para la resolución de las disputas. Mancuso afirma que "[...] un alto porcentaje de líderes Wayúu son mujeres [...]” (Mancuso 2006) (lo cual encuentra su razón de ser en la función de frontera desempeñada por las mujeres wayús en la cotidianidad) y, en esta dirección, estas mujeres-líderes se ubican en la ambigüedad de dominar el espacio de la discusión pública con grupos externos y no poseer la potestad de tomar las decisiones determinantes en el curso de los conflictos. 
La unión entre las dinámicas promovidas por la función de frontera, las generadas desde el papel de liderazgo en momentos de conflicto y la ambigüedad de estos dos roles se puede advertir en las posiciones asumidas por las mujeres wayús en el marco de la disputa de bahía Portete. Desde que comenzó a agudizarse el conflicto entre diversos clanes wayús por el monopolio de las actividades del puerto, las mujeres, en su papel de intermediarias y lideresas, tomaron diversos cursos de acción para defender los intereses de sus apushi. En primer lugar, en el informe de Memoria Histórica (Colombia, Centro Nacional de Memoria Histórica 2010, 133) se explica que, debido a los múltiples proyectos de explotación minera que se estaban consolidando en la Guajira en las últimas décadas, varias mujeres lideresas crearon organizaciones sociales que tenían como objetivo resistir y negociar con las multinacionales. En los hechos precedentes a la masacre de bahía Portete en el 2004, estas organizaciones operaron como espacios de discusión y de resistencia frente al accionar violento de diversos clanes en el momento de reclamar su potestad sobre el puerto y, con mayor énfasis, frente a la incursión paramilitar en la región. Las mujeres wayús organizaron varias reuniones en las que ponían a discutir a las diferentes partes enfrentadas sobre el mejor curso a seguir para entablar negociaciones y fueron ellas quienes denunciaron abiertamente ante el Estado la presencia y las amenazas del paramilitarismo en la zona.

En segundo lugar, un hecho significativo en relación con la presencia femenina en el conflicto de bahía Portete fue lo acaecido en días posteriores al asesinato de Francisco Iguarán 
Epinayú. Según señalan algunos testimonios, esta muerte pudo ser causada por la familia de Chema Bala, como reacción a la noticia de que las familias Fince Epinayú y Fince Uriana tenían el poder sobre el puerto en virtud de su historia como poseedores de esa parte del territorio. Aunque la acusación de asesinato nunca se pudo corroborar, desde ese momento las tensiones entre dichas familias aumentaron considerablemente, pues los clanes Fince Epinayú y Fince Uriana le exigían a Chema Bala una compensación material por la muerte de su pariente, y en vista de que no recibían respuesta alguna, proclamaron venganza. A raíz del aguzamiento de las hostilidades entre estos apushi, las mujeres intervinieron y cerraron el puerto como acto de presión para que las partes enfrentadas llegaran a algún acuerdo. Como bien lo indica el informe de Memoria Histórica, este accionar de las mujeres wayús frente a la disputa que estaba empeorando es característico de sus papeles como mediadoras, consejeras y conciliadoras en los conflictos (Colombia, Centro Nacional de Memoria Histórica 2010, 146).

En tercer lugar, es de resaltar la importancia de las hermanas de Chema Bala en la planeación y ejecución de la masacre. En este caso, se puede advertir cómo las mujeres transmiten información a su bando sobre los puntos débiles del enemigo; según algunos testimonios, "ellas [las hermanas de Chema Bala] les señalaban a los arijunas o paramilitares, que era a ellos a los que había que agarrar o gritaba dándole órdenes para que sacara las cosas de la casa de Ocha (sic)" (Colombia, Centro Nacional de Memoria Histórica 2010, 98). En su rol de comunicadoras y de seres 
de frontera en medio de un conflicto, las mujeres pueden recopilar y transmitir información relacionada con el enemigo que sea útil para su línea familiar. Esto es justamente lo que hicieron las hermanas de Chema Bala en el momento de la masacre: les comunicaron a los paramilitares datos precisos sobre las familias enemigas, sobre quiénes eran las lideresas más importantes para la comunidad y sobre qué aspectos debían atacar si querían generar gran impacto en la forma de vida wayú.

Estas tres líneas de acción que tomaron las mujeres en el conflicto por el puerto de bahía Portete generaron una consecuencia que puede catalogarse como "ambigua” en el sentido explicado arriba: "el posicionamiento de la mujer como intermediadora, vocera o resistente en este ámbito público, las hacía más vulnerables al ataque de las nuevas estructuras armadas ilegales que pretendían convertirse rápidamente en el actor dominante en la zona" (Colombia, Centro Nacional de Memoria Histórica 2010, 149). En efecto, al presentarse como lideresas resistentes, como espías o como consejeras, las mujeres wayús fueron percibidas como las enemigas directas de los paramilitares, como las que estaban al frente del conflicto, y esto supuso que las vulneraciones producto de la disputa se recargaran sobre esas mujeres líderes que se opusieron a la intromisión paramilitar desde su inicio. Entonces, además de atacar a las mujeres porque esto implicaba la violación a los códigos de guerra wayús, y con ello, el rompimiento de un referente central de lo que esta comunidad considera valioso y vital, los paramilitares no agredieron a mujeres escogidas al azar: mataron y torturaron 
a las lideresas que se habían resistido abiertamente a su presencia en la zona. Por ejemplo, Rosa Fince Uriana, una de las víctimas de la masacre, era una famosa comerciante que era conocida en la región por su prestigio, al poseer varios bienes como animales y víveres. Pero su rol central en el marco del conflicto por el puerto fue el de intermediación: ella era la líder del clan Uriana y, junto con otras mujeres, encabezó la oposición a los paramilitares. Otro ejemplo de una mujer lideresa torturada y asesinada en la masacre es el de Margarita Fince Epinayú: ella participó en la creación de la Asociación Indígena de Autoridades Traicionales y era reconocida en la comunidad por su papel de preservar la tradición wayú, al relatar las historias memorables de este pueblo. También se opuso a la incursión paramilitar y por eso fue asesinada. Teniendo en cuenta estos casos, se puede decir que "los victimarios, al torturar y asesinar a Margoth y Rosa, al saquear sus casas y robar objetos de gran valor cultural, operan bajo la lógica de propiciar un castigo ejemplar a estas mujeres que se caracterizan por su intermediación y liderazgo social, pero también por su resistencia a la ocupación paramilitar [...]" (Colombia, Centro Nacional de Memoria Histórica 2010, 84).

La ambigüedad de los roles que las mujeres wayús asumieron en la disputa de bahía Portete descansa, entonces, en que el hecho de ser figuras públicamente visibles en la arena del conflicto las pone en la mira de los ataques propiciados por los enemigos; a pesar de que ellas no son las que toman las decisiones últimas o las que encarnan las funciones propias del "guerrero wayúu" de tomar las armas y defender cuerpo a 
cuerpo a su comunidad en una batalla, las mujeres se encaran con el otro, resisten a él, negocian con él y, como en el caso de bahía Portete, lo enfrentan a través de denuncias y de acusaciones públicas. Esto lleva a que el enemigo las conciba como enemigas, como aquellas que se están enfrentando a él en el momento de defender la forma de vida propia. En este sentido, los paramilitares torturaron a las mujeres porque ellas eran sagradas en el marco de la guerra wayú, pero, además, atacaron a esas mujeres en particular porque ellas se enfrentaron a su accionar y tomaron acciones concretas para oponerse a sus lógicas y expulsarlos del territorio. Por esto se puede decir que las mujeres wayús se convirtieron en enemigas de los paramilitares: al oponerse a su accionar y tomar medidas para defender la forma de vida wayú frente a la incursión del enemigo extranjero, las mujeres se ubicaron “en la mira” de los actores armados. Esas mujeres que denunciaban, protestaban y se oponían a las lógicas paramilitares con el fin de defender la forma de vida wayú debían ser silenciadas, pues constituían un obstáculo para los objetivos paramilitares de conquista territorial. En este caso, la violencia sexual fue la estrategia escogida por los actores armados para destruir a las mujeres wayús enemigas.

\section{La diferencia sexual: retos al concepto de lo político y caracterización de la enemistad de bahía Portete}

Si tanto mujeres como hombres wayús se presentaron públicamente como enemigas y enemigos de los paramilitares, ¿por qué las mujeres fueron atacadas sexualmente y los hombres no? ¿Tiene esta cuestión implicaciones sobre el 
concepto de lo político? ¿Le impone retos a la conceptualización schmittiana? ¿Es pertinente, en el marco de una reflexión sobre lo político, la guerra y el conflicto proponer la distinción entre hombres y mujeres, enemigos y enemigas? Schmitt diría que no. Saber que las mujeres wayús cumplieron roles específicos que las convirtieron en enemigas de los paramilitares y que esto se tradujo en su posterior tortura y muerte puede ser información relevante sociológicamente, pero no impacta en la filosofía política. Schmitt diría que tener datos sobre la manera en que las mujeres asumen ciertos roles distintos a los adoptados por los hombres en los conflictos históricos concretos no parece un asunto relevante en el contexto de la elucidación conceptual de lo político, pues no es algo que afecte el modo de pensar en el amigo, el enemigo o en cómo la tensión entre estos genera dinámicas de hostilidad absoluta. Puesto en otros términos, el concepto de lo político de Schmitt no tiene sexo: no se refiere a hombres o mujeres luchando por su forma de vida, sino a enemigos y amigos agrupándose alrededor de la oposición hacia otro o de la defensa de lo propio; las categorías de "amigo" y "enemigo" son neutrales en relación con el género: no importa si el enemigo es un grupo de hombres o de mujeres, porque lo esencial aquí es la enemistad, esto es, la forma como una unidad política se opone a un enemigo que amenaza directamente su existencia. El género no impacta en las lógicas de enemistad entre unidades políticas: allí no importan las particularidades de los individuos que componen a los grupos humanos; lo central es, más bien, 
cómo las unidades políticas vinculadas por una forma de vida homogénea se enfrentan entre sí.

Según Derrida, Schmitt respondería lo siguiente a la sugerencia de pensar en la diferencia sexual como parte de la arena de lo político:

Desde luego -diría [Schmitt]- puede uno inquietarse por la ausencia de la mujer en este análisis, incluso puede descubrirse en ella lo que llama usted su clandestinidad. Puede uno también dedicarse a explicaciones sociológicas o psicoanalíticas sobre el tema. Puede uno incluso protestar en nombre de la moral, de la justicia o de la igualdad universal de los derechos del hombre. Todo eso puede ser legítimo, urgente incluso, y estaría dispuesto, en ciertas condiciones, a asociarme a usted, y a compartir su interés por la causa de las mujeres, que son por otra parte indispensables, en efecto, en la formación de los grupos y de los pueblos enemigos, sin los cuales no habría política. Pero, mire usted, esa causa puede depender de todas esas disciplinas, el psicoanálisis, el derecho, la moral, el derecho, incluso la religión, y usted puede tratar esta cuestión desde el punto de vista económico. Pero resulta que todo eso no tiene ninguna pertinencia política en cuanto tal. (Derrida 1998b, 181-182)

La diferencia sexual sería, entonces, una cuestión sociológica, psicoanalítica, histórica o moral, pero no política. El problema de esta perspectiva radicaría en que aquí está hablando, nuevamente, el Schmitt reduccionista, el Schmitt 
ciego ante las diferencias que operan y son fundamentales para entender los conflictos reales. Justamente, Derrida afirma que al pasar por alto la cuestión de la diferencia sexual como central a la hora de pensar en lo político, Schmitt construye una teoría política desde "el desierto", es decir, una teoría que pretende ser unitaria y total, pero que, en este proceso, oculta las diferencias, particularidades, matices y retos que constantemente amenazan con quebrar dicha homogeneidad. En palabras de Derrida, “[...] lo que sorprende en esta filosofía de la guerra sin concesiones [la filosofía de Schmitt], en esta puesta en escena del dar muerte 'física', en esta implacable lógica de la hostilidad absoluta, lo que debería saltar a la vista pero pasa desapercibido como la ausencia misma, lo que aparece hasta fundirse en pleno desierto es la mujer o la hermana" (Derrida 1998b, 180). La mujer se funde en el desierto, dice Derrida; la figura de la hermana es ocultada por esa filosofía política reduccionista y homogenizante que aparentemente busca abarcar y dar cuenta de todos los conflictos, pero que, en realidad, oculta y esconde realidades que pueden retarla.

Pero esa imagen del desierto, entendida como una filosofía política con pretensiones de totalidad, unidad y homogeneidad se refiere, de manera más concreta, a la ceguera schmittiana frente a la diferencia sexual:

Lo que una visión macroscópica puede poner en perspectiva, desde muy lejos y desde muy alto, es un cierto desierto. Ninguna mujer. Un desierto poblado, ciertamente, un desierto lleno en pleno desierto, e incluso, dirán algunos, 
un desierto negro de mundo: sí, pero hombres, hombres, hombres, tras siglos de guerra, y vestidos, sombreros, uniformes, sotanas y guerreros, coroneles, generales, partisanos, estrategas, y políticos, profesores, teóricos de lo político, teólogos. Buscaríais en vano una figura de mujer, una silueta femenina, y la menor alusión a la diferencia sexual. (Derrida 1998b, 179)

¿A qué apunta el señalamiento de Derrida? ¿Qué significaría un concepto de lo político que no sea ciego ante la diferencia sexual? En principio, es posible pensar que Derrida apunta a resaltar el papel que las mujeres han tenido en los conflictos; las guerras no sólo se han desarrollado a partir de los papeles jugados por los hombres, sino que las mujeres también han sido guerreras, partisanas, estrategas. En este contexto, el caso de bahía Portete añadiría nueva información al concepto de lo político, al mostrar cómo las mujeres pueden enfrentarse al enemigo y participar activamente en las discusiones vitales para el mantenimiento de la forma de vida propia. Sin embargo, esta perspectiva es vacía, inocua y engañosa, pues la diferencia sexual sería una mera anécdota que no tendría impacto alguno en lo político o en la definición y caracterización de la enemistad y del conflicto. Señalar los diversos roles que han cumplido mujeres y hombres en las guerras y disputas revestiría a lo político con datos históricos, pero no le plantearía retos a la filosofía política; aquí no habría un problema filosófico. Una perspectiva de tales características puede resultar engañosa, en tanto que pone de manifiesto la distinción entre mujeres 
y hombres y, en este sentido, parece ser una perspectiva de diferencia sexual, cuando en realidad no lo es. Siguiendo a Derrida, es posible decir que introducir la diferencia sexual en el marco del concepto de lo político supone asumir una posición que efectivamente ponga a prueba a la conceptualización schmittiana y ubique a las diferencias entre hombres y mujeres como asuntos definitorios de la enemistad y del reconocimiento del otro-enemigo. En este caso, distinguir entre hombres y mujeres en los conflictos ya no remitiría al ámbito de la historia, la sociología o el psicoanálisis, sino a la filosofía política, ya que se convertiría en una cuestión vital para entender cómo opera lo político en las disputas concretas.

Derrida ha sido enfático en señalar la importancia de pensar en la unidad política en términos de la diferencia y de la manera como la heterogeneidad al interior de los grupos humanos genera lógicas de enemistad a las que un concepto de lo político pensado desde el conflicto tendría que atender si se pretende que sea útil para entender los conflictos reales. En esta dirección, el caso de bahía Portete le exige a Schmitt la introducción de la diferencia sexual. Si el objetivo es entender el carácter del conflicto que allí se gestó, el modo en que se reconocieron los enemigos y la repercusión de esto en el tipo de violencia ejercida no se puede pasar por alto el hecho de que las mujeres wayús que se presentaron como enemigas de los paramilitares fueron amenazadas y vulneradas sexualmente, mientras que los hombres wayús enemigos no sufrieron este tipo de torturas vinculadas con lo sexual. Tanto hombres como mujeres se 
enfrentaron a los paramilitares en la lucha por el puerto: los hombres wayús realizaron emboscadas para atacar cuerpo a cuerpo a los actores armados que estaban entrando a bahía Portete y las mujeres se encargaron de interpelarlos, denunciarlos y oponérseles directamente a través de la palabra. No obstante, los métodos de intimidación usados por los paramilitares para atacar a la población indígena difieren cuando se vulnera a los hombres y cuando se ataca a las mujeres. Los cuerpos de las mujeres fueron mutilados y torturados en zonas de clara referencia sexual y reproductiva como el útero y los senos y, además, antes y después de la masacre, los paramilitares dibujaron grafitis en las casas de las mujeres con el fin de intimidarlas y mostrarles lo que les podía pasar si continuaban con su lucha por el puerto de bahía Portete. Siguiendo el informe de Memoria Histórica, "los grafiti son otra forma de violencia sexual y ultraje a las mujeres y a la comunidad. Los pintan en la casa de Rosa Fince Uriana posterior a la masacre con figuras de mujeres violadas por la boca, la vagina y el ano y letreros con mensajes ofensivos que recordaban las violaciones de las mujeres, el rasgamiento de los senos, el abrir de los vientres; además contienen amenazas directas a lideresas con diferentes formas de violación y tortura sexual" (Colombia, Centro Nacional de Memoria Histórica 2010, 86).

A continuación se muestran las fotografías de los grafiti tomadas por los funcionarios del Centro Nacional de Memoria Histórica: 
Figura 3.2. Grafiti en las paredes de la casa de Rosa Fince Uriana y en el centro de salud, 2009 y 2010.
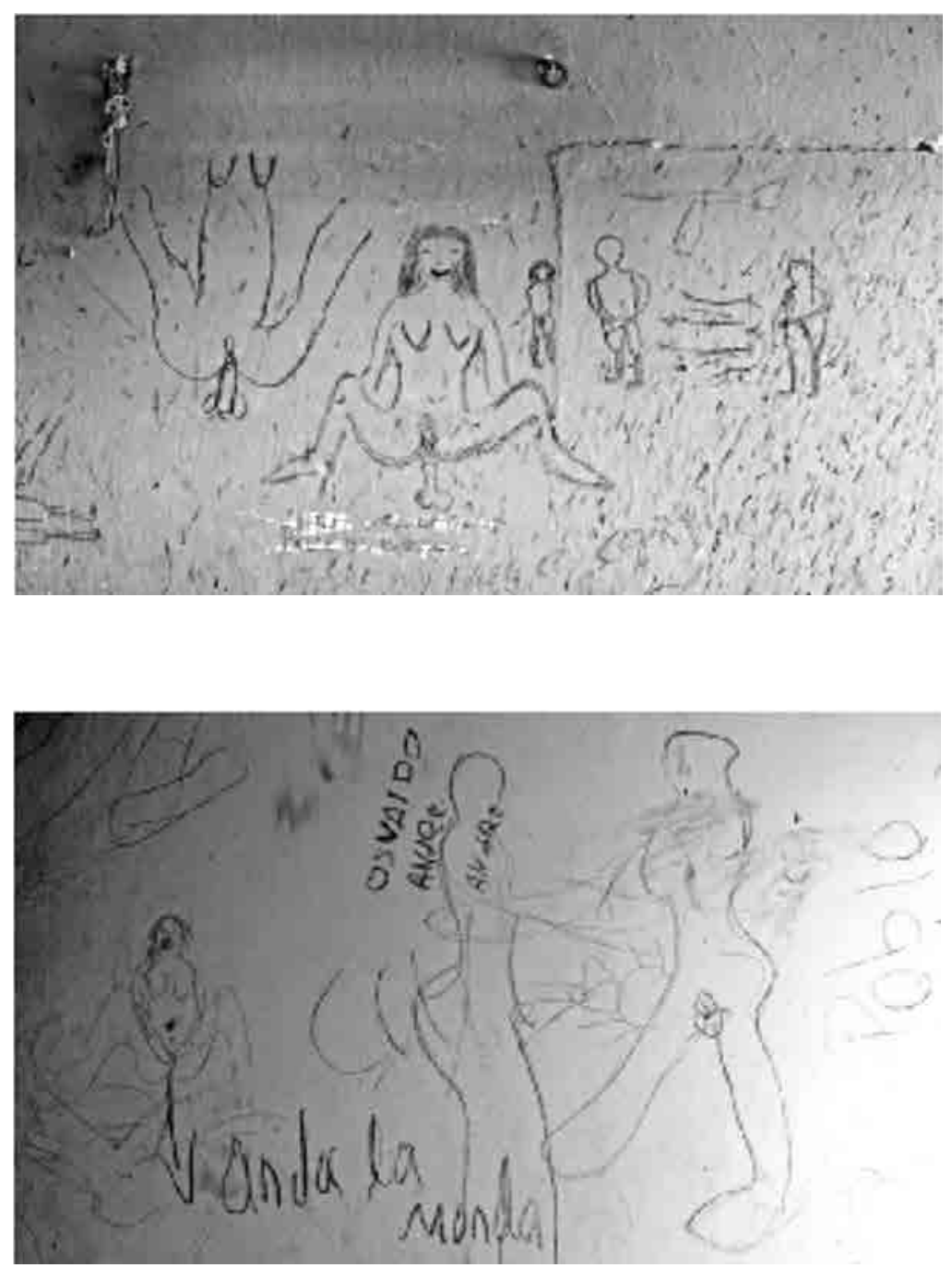

Fuente: Colombia, Centro Nacional de Memoria Histórica 2010, 88. 
En las imágenes, se pueden advertir las amenazas sexuales que los paramilitares utilizaron en contra de las lideresas wayús para intimidarlas y frenar su lucha por el territorio. Las recurrentes referencias al pene y a la vagina y los dibujos de armas de fuego que se convierten en penes son algunos de los signos contundentes de violencia sexual. Y es que, en definitiva, el tipo de violencia que atravesó los eventos de bahía Portete en relación con las mujeres estuvo constantemente ligado con lo sexual, a diferencia de las vulneraciones recibidas por los hombres, quienes fueron atacados a través de otros métodos -igualmente crueles-como la mutilación de las extremidades o los disparos. ${ }^{43}$ ¿En

43 Con respecto a las estrategias de intimidación llevadas a cabo por los paramilitares hay que hacer algunas anotaciones. En primer lugar, de acuerdo con el informe del Centro Nacional de Memoria Histórica titulado Mujeres y guerra. Víctimas y resistentes en el Caribe colombiano (2011), uno de los mecanismos usados con más frecuencia por los grupos paramilitares para someter a las poblaciones es la violencia sexual, la cual se ejecuta en dos sentidos principales: por un lado, como violencia cotidiana utilizada para mantener controladas a las personas, es decir, para demostrar constantemente quién tiene el poder y asustar a los que piensan resistir o enfrentarse, y por otro lado, como violencia ligada con la idea del "castigo ejemplar", esto es, violencia cuyo fin es atacar a líderes resistentes a la incursión paramilitar, y así mostrar públicamente lo que puede pasar a quienes se opongan a su accionar. La masacre de bahía Portete, y en particular, las vulneraciones recibidas por las mujeres wayús se enmarcan en esta línea de actividad paramilitar, específicamente, en el uso de la violencia sexual como "castigo ejemplar". En segundo lugar, el hecho de que en el caso de bahía Portete los paramilitares atacaran sólo a las mujeres con violencia sexual no significa que los hombres hayan estado exentos de este tipo de prácticas en otros contextos; por el contrario, se han documentado varios casos de violencia sexual efectuada a hombres y a personas homosexuales en distintos lugares de dominio paramilitar en el país. Esto introduciría nuevos e importantes elementos a las reflexiones que siguen a continuación, pero, en lo que concierne a los límites del presente texto, me restringiré a estudiar la masacre de bahía Portete y la diferencia entre los métodos de intimidación efectuados en contra de las mujeres y de los hombres. 
qué radica la diferencia en las estrategias de intimidación efectuadas hacia los enemigos y enemigas wayús? ¿Es pertinente señalar dicha distinción en relación con el concepto de lo político?

Como se advirtió en el capítulo anterior, el conflicto en bahía Portete llegó a la hostilidad absoluta, en tanto que se trató de una guerra encabezada por los mismos hermanos de la comunidad, aliados con actores armados externos, para atacar a integrantes de su propio grupo. En este escenario, las regulaciones sobre la guerra o sobre la manera de enfrentarse con el enemigo fueron trastocadas. A diferencia de los conflictos regulados, en los que "el enemigo está a mi propio nivel" (Schmitt 1966, 118) y hay acotamientos sobre el modo de enfrentarlo y de darle muerte, en las guerras de partisanos $y$, en general, en aquellas disputas que superan los marcos de la guerra tradicional -como en el caso de bahía Portete- el enemigo es visto como susceptible de ser eliminado a toda costa y a partir de cualquier medio posible. ${ }^{44}$ Según Derrida, ese momento de "dar muerte" revela el carácter del conflicto que se lleva a cabo: cuando hablamos de guerras acotadas, dar muerte está regulado, no todas las formas de acabar con el otro están permitidas. En contraste, cuando de guerras no

44 Aunque, para Schmitt, lo esencial de lo político no es el momento de la guerra o de dar muerte al enfrentarse cuerpo a cuerpo con el otro, sino la tensión que existe entre amigos y enemigos, la cual no necesariamente conlleva al combate físico, los conflictos no acotados sí suelen suponer la eliminación de los otros y, generalmente, implican una eliminación física que rebasa los límites de sólo matar, pues los conflictos no regulados traen consigo la sevicia y la ejecución de diversas prácticas cuyo fin es degradar al enemigo y atacarlo de manera que se transmita el mensaje de quién tiene el poder. 
reguladas se trata, no hay límite alguno sobre dar muerte; el otro es percibido como un enemigo absoluto a quien se puede eliminar sin restricción. Un examen de los conflictos requeriría, entonces, estudiar los modos de enfrentamiento entre los enemigos, ya que esto permite pensar en la naturaleza de la disputa, en cómo se reconoce al enemigo, en cuál es el carácter de la hostilidad y en el tipo de enemistad que subyace al conflicto.

Derrida afirma que la muerte producto de un conflicto político no es natural: "la muerte del hombre, implicada así en este concepto de enemigo, es decir, en toda guerra, exterior o civil, no es ni una muerte natural, puesto que el enemigo tiene que ser matado, ni un asesinato, pues matar en la guerra no se considera un crimen", sin embargo, cuando la guerra rompe con las regulaciones del ius belli, la distinción entre matar como parte de la guerra y el crimen se vuelve difusa y se llega "al salvajismo de una violencia que no respeta las leyes de la guerra y el derecho de gentes" (Derrida 1998b, 143). El punto crucial aquí es que cuando las lógicas de lo político llevan a la guerra la muerte que allí se produce no es natural: al enemigo se le mata y la manera como se le da muerte es diciente con respecto al carácter del conflicto. No es lo mismo una muerte que se produce en el contexto de una guerra regulada a una muerte que se efectúa con sevicia en el marco de una guerra irregular: mientras en el caso de la primera al enemigo se le reconocen ciertas prerrogativas y se le mata en condiciones reguladas, en el segundo contexto el enemigo no es considerado como un igual y, por esto, la manera como se le da muerte transmite un mensaje sobre 
quién tiene el poder absoluto, sobre qué forma de vida impera y sobre la forma de vida que sucumbe. Nuevamente, no es fortuito que los paramilitares, en medio de su alianza con Chema Bala, hayan atentado contra los referentes culturales que se consideraban vitales en la forma de vida wayú: en una guerra no regulada, lo que usualmente se toma como intocable y sagrado es vulnerado, con el fin de degradar al enemigo y de acabar totalmente con su forma de vida.

Pero habría que llevar la cuestión más allá: un estudio de la masacre de bahía Portete a la luz de las herramientas conceptuales de la teoría del conflicto de Schmitt no sólo implicaría poner de manifiesto que en medio de una disputa no regulada los enemigos paramilitares, aliados con clanes wayús, trastocaron los códigos de guerra para desestructurar la forma de vida de este grupo indígena; también habría que preguntarse por la forma escogida por los actores armados para dar muerte a sus enemigos indígenas: ¿ por qué las mujeres fueron atacadas sexualmente y los hombres no? ¿Qué lógicas del reconocimiento del enemigo operan en este caso cuando el enemigo es una mujer? ¿En qué se diferencian de las que operan cuando es un hombre? ¿Qué tipo de conflicto se revela a partir del examen de los métodos de dar muerte e intimidación elegidos por los paramilitares para acabar con la forma de vida wayú? Estas cuestiones dejan de ser meras anécdotas históricas en el momento en que recaen sobre la noción de enemistad: si la naturaleza de los conflictos y de las enemistades puede ser entendida al atender a la manera en que los enemigos se enfrentan, matan y agreden entre sí la diferencia en los métodos de intimidación para acabar 
con enemigos y enemigas debe ser pensada como parte del concepto de lo político. ${ }^{45} \mathrm{La}$ diferencia sexual, entonces, es un concepto clave a la hora de entender cómo se reconoce, define y enfrenta al enemigo en los conflictos. Bajo esta perspectiva, en lo que sigue recurriré a la metodología del punto de vista feminista para esclarecer los términos desde los que se tendría que proponer la noción de diferencia sexual como parte de las lógicas de lo político y como un elemento central para considerar en relación con la comprensión del caso de bahía Portete y del conflicto que allí se gestó.

45 El uso de la violencia sexual contra las mujeres es un método recurrente en medio de los conflictos y guerras. Catharine Mackinnon (1993) ha estudiado ampliamente este fenómeno, particularmente, a partir del caso de las mujeres croatas violadas y torturadas sexualmente por los enemigos serbios en medio del conflicto entre dichos países. De igual manera, durante la dictadura de Augusto Pinochet en Chile, muchas mujeres que se oponían al régimen fueron violadas y torturadas, con el fin de silenciarlas y castigarlas por sus denuncias (Mujeres violadas en la dictadura chilena rompen su silencio con historias dramáticas 2010). Durante el holocausto también se recurrió a la violencia sexual para atacar a las mujeres judías (Suárez Toro 2011). Y el caso colombiano no se queda atrás: de acuerdo con un informe realizado por la Casa de la Mujer, aproximadamente medio millón de mujeres fueron violadas entre el 2001 y el 2009 en el contexto del conflicto armado. Todos estos casos ponen de manifiesto que la violencia sexual es una estrategia recurrente para doblegar a las enemigas en el marco de la guerra, por esta razón es central preguntarse y darle un lenguaje a este fenómeno en los análisis del conflicto y de lo político. 


\section{El "punto de vista feminista" y la diferencia sexual: la experiencia de género y las nuevas miradas al conflicto ${ }^{46}$}

En palabras de Sandra Harding, uno de los principios centrales de la llamada metodología del "punto de vista feminista" es el hecho de que "los asuntos feministas no pueden ser encasillados e ignorados sólo como asuntos de mujeres, sino que, en su lugar, deben ser vistos como valiosos en relación con la teoría, la metodología y el pensamiento político en general”47 (Harding 2004, 2). A lo que Harding

46 En este punto es preciso señalar que la cuestión de la diferencia sexual ha sido ampliamente examinada por corrientes de estudios de género que toman como base a la filosofía de Derrida. Ver, por ejemplo, los textos de Kamuf (2002), Poovey (2001) y Alcoff (2001). Sin embargo, estos estudios se concentran, principalmente, en abogar por eliminar las categorías de mujer y hombre, con el fin de no dictaminar las conductas sexuales a partir de una normativa heterosexual y, con ello, contribuir a eliminar la violencia inherente a una estructura de género binaria que vulnera y excluye a quienes no se acomodan a ella. Si bien estos análisis son pertinentes e importantes para estudiar la cuestión de la diferencia sexual, me distanciaré de ellos para plantear el asunto de la hermana en el caso de bahía Portete. Mi interés por la metodología del punto de vista radica en que muestra la pertinencia de introducir la diferencia sexual en la filosofía política, al dar cuenta de unas lógicas de violencia, jerarquías e injusticias que operan en contextos concretos y que se sostienen sobre concepciones y prácticas sociales vinculadas con el "ser hombre" y el "ser mujer"; esto no excluye la posibilidad de que las teorías de género que se derivan de Derrida puedan ser provechosas y pertinentes en el momento de concebir sistemas de género diferentes que rompan con la violencia producida desde la estructura heterosexual y binaria, pero, en lo que respecta a este texto, me interesa pensar en la violencia sexual contra las mujeres wayús como un elemento que opera efectivamente en el conflicto y desde el cual se revelan relaciones de poder, violencias e injusticias en el caso concreto de bahía Portete.

47 Todas las citas de los artículos compilados en S. G. Harding (2004) son traducciones propias. 
apunta con esta formulación es a señalar que los reclamos del feminismo no deben ser pensados como cuestiones aisladas de las preocupaciones de la filosofía política; más bien, el feminismo debe concebirse como un cuerpo de conceptos, reclamos y reivindicaciones que le impone retos a las conceptualizaciones filósoficas tradicionales a la luz de la introducción de la diferencia sexual como elemento vital para pensar y conceptualizar la realidad. Como bien lo indica Celia Amorós, el feminismo parte de afirmar que “[...] las demandas de las mujeres exigen replanteamientos conceptuales radicales en sus esquemas teóricos [los de la filosofía]" (Amorós 2000, 12). Y es que, en efecto, el punto de vista feminista apela a retar los esquemas filosóficos con base en lo que Amorós denomina "las demandas de las mujeres”, expresión que puede ser equiparada a la de "experiencia femenina" articulada por las teóricas del punto de vista feminista para plantear las bases centrales de su metodología ${ }^{48}$

48 Con respecto a la noción de experiencia femenina como base de la metodología del punto de vista han surgido varias críticas. En primer lugar, se ha dicho que el punto de vista parte de una concepción esencialista de los géneros (Hirschmann 2004, 317), en el sentido en que parece asumir que las mujeres comparten una experiencia común que las define como tales. Esto lleva a la segunda crítica: para algunos, el punto de vista feminista, además de ser esencialista, es universalista, puesto que supone que todas las mujeres tienen la misma experiencia. Judith Butler ha sido una de las teóricas que más ha desarrollado estos cuestionamientos al feminismo; de acuerdo con ella, el principal problema de las teorías feministas es que tienen necesariamente que tomar como base el concepto de “mujer” y esta es una categoría difusa y cuya definición no es clara. En palabras de Butler, “si una 'es' mujer, es evidente que eso no es todo lo que una es; el concepto no es exhaustivo, no porque una 'persona' con un género sobrepase los atributos específicos de su género, sino porque el género no siempre se constituye de forma coherente o consistente en contextos históricos distintos, y porque se 


\section{Aunque existen diversas formas de aplicar el punto de vista de acuerdo al tipo de feminismo que se defienda y a}

entrecruza con modalidades raciales, de clase, étnicas, sexuales y regionales [...]” (Butler 1990, 49). Pero además de que, para Butler, la experiencia de género no puede encasillarse en los conceptos de "mujer" o de "hombre", pues es maleable y se articula de distintas maneras en diversos contextos históricos, el feminismo también descansa sobre otro supuesto problemático, a saber: la idea de que existe una suerte de "patriarcado universal”, es decir, un sistema de dominación masculina de alcance universal que afecta a todas las mujeres y hombres de la misma manera. En esta dirección, dice Butler que las feministas ven en los casos históricos concretos ilustraciones o ejemplos de cómo funciona la dominación masculina y no prestan atención a los posibles problemas de "forzar" la realidad para que se ajuste a sus supuestos (Butler 1990, 49-50). Estas críticas imponen grandes retos a las teorías feministas y se enmarcan en un debate más amplio que ha sido llamado por Linda Alcoff como "la crisis de identidad de la teoría feminista” (Alcoff 2001, 65). Siguiendo a Alcoff, las teorías feministas actuales oscilan entre los dos polos de una tensión: por una parte, ciertas teorías feministas defienden que las categorías de mujer y de hombre se deben mantener porque remiten a experiencias de género ligadas a la biología o a prácticas sociales de largo alcance que no se pueden pasar por alto en el análisis social; por otra parte, las feministas influenciadas por el posestructuralismo rechazan " [...] la posibilidad de definir a la mujer como tal” (Alcoff 2001, 67), pues no hay una sola forma de pensar en el género y hay diversas mujeres atravesadas por diferentes experiencias que no se pueden capturar en una sola categoría. En esta tensión, las teóricas del punto de vista alegan que sus supuestos no son esencialistas ni universalistas, puesto que no piensan en mujeres y hombres como categorías basadas en la biología o en una esencia inmutable, sino como nociones constituidas socialmente y que varían de contexto en contexto. Sin negar la diversidad de "mujeres" y de "hombres" y la diversidad de contextos, las feministas del punto de vista sí defienden el mantenimiento de las categorías de género, puesto que estas resultan útiles para pensar los arreglos de género y de poder en situaciones históricas concretas. No se trata de generalizar o de buscar la confirmación del patriarcado universal, sino de examinar ciertos contextos con el objetivo de estudiar experiencias sociales compartidas que parecen definir lo que es "ser mujer" y "ser hombre" y, en vista de las diferencias que cada caso puede presentar, se pueden articular diversos puntos de vista que tengan en cuenta variables como raza o clase, además del género. De acuerdo con estas teóricas, eliminar la diferencia sexual supondría negar las dinámicas que responden a la diferencia sexual en algunos contextos concretos. 
las realidades a las que se intente responder, en general, las diferentes corrientes comparten un objetivo común: “[...] explorar (en oposición a asumir) cómo la experiencia de vida de la mujer difiere de la del hombre [...]" (Ramazanoglu y Holland 2002,61$)^{49}$ en virtud de las relaciones sociales concretas en las que se inscriben. La noción central aquí es la de experiencia: para las teóricas del punto de vista, ciertas dinámicas sociales conllevan a que, en determinados contextos, se pueda distinguir la experiencia de la mujer de la del hombre. Y se entiende "experiencia” como la relación, vínculo, compromiso o participación de un sujeto en el mundo social en el que está inmerso. Como bien lo indica T. Bowell, "la situación social de un agente epistémico -su género, clase, raza, etnicidad, sexualidad y capacidades físicas- juega un papel en la formación de lo que conoce y limita lo que es capaz de conocer" (Bowell 2011) 50 ; en este sentido, la noción de experiencia remite a cómo, desde una determinada situación social, los sujetos comprenden el mundo, participan en sus dinámicas, lo verbalizan, lo viven. Lo crucial aquí es que la constitución de los sujetos está inevitablemente atravesada por lo social: la experiencia es social en la medida en que la manera como los individuos entienden y participan en el mundo está enmarcada en coordenadas sociales precisas como el género, la raza o la clase.

49 Todas las citas de Ramazanoglu y Holland (2002) son traducciones propias.

50 Todas las citas de Bowell (2011) son traducciones propias. 
Bajo esta perspectiva, de todas las experiencias sociales posibles que pueden formar parte del desarrollo de un sujeto a lo largo de su vida, al punto de vista feminista le interesa la experiencia social del género, esto es, aquella referida a las relaciones entre unos sujetos que denominamos "mujeres" y otros que designamos como "hombres", ${ }^{51}$ en virtud de unos roles, prácticas, discursos y concepciones sociales históricamente constituidas. Siguiendo a Ramazanoglu y Holland, el punto de vista no asume a priori que las mujeres participan de un tipo de experiencia social particular diferente a la de los hombres; por el contrario, se trata, más bien, de examinar el modo como históricamente se han articulado experiencias sociales que han establecido lo que es "ser mujer" y "ser hombre" en distintos contextos y a partir de diversas prácticas concretas. Así, por ejemplo, algunas feministas del punto de vista se concentran en estudiar la experiencia social de la maternidad distinguiéndola de la paternidad, mientras otras se dedican a examinar la experiencia social de las mujeres afro o de las mujeres trabajadoras. En esta pretensión por indagar sobre los procesos históricos y sociales que han moldeado las formas de ser mujer y ser hombre descansa la idea de que las nociones de "mujer" y "hombre" no son naturales, sino que son formadas en virtud de procesos sociales. La "desna-

51 Habría que decir que el punto de vista feminista no parte de la "experiencia de género", sino, específicamente, de la “experiencia de género heterosexual”. Este sesgo ha sido fuerte y agudamente criticado por Judith Butler (Butler 1990, 7-33). Sería interesante y relevante examinar cómo las experiencias de género no heterosexuales pueden contribuir a plantear la cuestión de la "hermana" desde nuevas perspectivas. 
turalización" de las identidades y las experiencias de género es un principio que las teóricas del punto de vista feminista han tomado del marxismo y, en particular, de la idea de que las condiciones materiales de existencia definen la posición social desde la cual se comprenderá el mundo y se participará en él; la formación de mujeres y hombres responde, entonces, no a esencias pre-determinadas e inmutables, sino a procesos históricos concretos que distribuyen roles, tareas y formas de ver el mundo a distintos actores sociales.

Tomando lo anterior como presupuesto, Nancy Hartsock ha desarrollado los vínculos entre marxismo y feminismo alrededor de la noción de "punto de vista". De acuerdo con esto, el "punto de vista" se sostiene sobre cinco elementos: en primer lugar, supone la idea de "vida material” de Marx, según la cual la relación de los sujetos con los medios y sistemas de producción “[...] no sólo estructura sino que impone límites al entendimiento de las relaciones sociales” (Hartsock 2004, 37). En otras palabras, para Marx, la posición social que se ocupe en relación con el proceso de producción estructura y define la manera como los sujetos entienden el mundo; así, la experiencia del obrero se caracteriza por la manipulación directa de las materias primas de la producción, mientras la del capitalista se define por no interactuar directamente con los medios de producción y por recibir los beneficios del trabajo del obrero. Estas dos perspectivas del mismo sistema proveen dos puntos de vista diferentes, dos tipos de experiencia que perfilan dos formas de ver y estar en el mundo. De acuerdo con Hartsock, lo mismo puede aplicar para las estructuras de género: históricamente se han asignado tareas 
a hombres y a mujeres que implican dos formas de relacionarse con los elementos del mundo material; por ejemplo, las mujeres se han encargado de las tareas de reproducción y crianza de los hijos en el ámbito de lo privado, mientras los hombres han sido asignados en las tareas públicas, ya sea en el trabajo en las fábricas o en labores intelectuales o "abstractas". 52

Pero, como bien lo indica Harding, el punto de vista feminista no es un proyecto etnográfico (Harding 2004, 6), pues su objetivo no es simplemente poner de manifiesto los diferentes puntos de vista relacionados con el género que se articulan en relación con prácticas y estructuras sociales precisas. El punto de vista es, sobre todo, un proyecto conceptual y político, en el sentido de que tiene como fin mostrar las relaciones de poder, violencias e injusticias que

52 En este punto vale la pena aclarar que las teóricas del punto de vista feminista no buscan capturar la experiencia de todas las mujeres alrededor de la función de la crianza ni la de todos los hombres alrededor de las labores intelectuales. Esta es una distinción que es válida para algunos contextos pero para otros no aplica. De ahí que muchas feministas del punto de vista se hayan preocupado por articular diferentes puntos de vista que den cuenta de las diferencias en las experiencias de las mujeres. Por ejemplo, Patricia Hill Collins introduce la variable de raza para mostrar que el punto de vista de las mujeres afro difiere del de las mujeres blancas y, más aún, si además de la raza se introduce la clase, el punto de vista de las mujeres afro de clase baja se distingue radicalmente del de las mujeres blancas de clase alta. Según Collins, la interacción entre las categorías de género, clase y raza proporciona una concepción más compleja de la noción de punto de vista y de la vida social en general. Para conocer su enfoque "interseccional", ver Collins (2004). De igual manera, algunas feministas también han elaborado puntos de vista no occidentales, con el fin de mostrar que algunas de las categorías usadas por las feministas occidentales para dar cuenta de la experiencia femenina se quedan cortas en el momento de tener en cuenta las experiencias de las mujeres del mundo no occidental. Con respecto a esto ver Narayan (2004). 
se derivan, tanto del sistema de relaciones de género que se ha articulado históricamente en diversos contextos, como de la invisibilización conceptual de dichas injusticias. ${ }^{53}$ De ahí que el segundo elemento identificado por Hartsock como característica fundamental del punto de vista sea la idea igualmente planteada con base en la teoría de Marx- de que el sistema de género que le asigna ciertos roles a las mujeres distintos a los ejercidos por los hombres es un sistema de dominación, puesto que, o bien las labores femeninas son vistas como inferiores o no valiosas, o bien dichas tareas generan estereotipos o propician violencia sobre las mujeres.

El tercer elemento que se deriva del anterior indica que la injusticia del sistema de género descansa en el hecho de que "la visión de la clase dominante (o el género dominante) estructura las relaciones materiales en las cuales todas las partes están obligadas a participar [...]” (Hartsock 2004, 37). Para Hartsock, así como desde el marxismo se afirma que el sistema de producción está construido desde el punto de vista del beneficio del capitalista y a costa del trabajo del proletario, el sistema de género está articulado en provecho

53 De ahí que la traducción al español del término "feminist standpoint" como "punto de vista feminista" no sea completamente acertada, pues esta metodología no sólo muestra un punto de vista frente a la realidad, también es una posición que busca revelar las contradicciones del sistema en pro de promover y pensar en relaciones sociales justas; desde los inicios de la metodología, en el marco del surgimiento de las corrientes del feminismo de segunda ola, "standpoint" remitía al talante crítico y normativo de las teorías feministas del periodo. El término "punto de vista" no logra capturar este elemento normativo y cuestionador de la metodología. Sin embargo, para facilitar la lectura, continuaré usando "punto de vista feminista", con la advertencia de que el término no es totalmente conveniente. 
del punto de vista masculino y en desventaja del femenino. Por ejemplo, siguiendo el interés de Hartsock por estudiar la relación de las mujeres con los medios de producción, se puede decir que ellas se encuentran en desventaja, pues sus labores no son valoradas como trabajo, mientras las de los hombres sí son remuneradas y reconocidas socialmente como productivas e importantes. El ejemplo muestra cómo la división sexual del trabajo repercute en el no reconocimiento social y económico de las tareas femeninas y en la valoración positiva de lo masculino. En esta dirección, la manera como el "género dominante" se vincula con el sistema de producción determina el modo de interpretar y de participar en las relaciones sociales: el trabajo de las mujeres es valorado desde los parámetros del trabajo realizado por los hombres; es desde esos términos que se juzgan y reconocen las actividades de las mujeres.

En cuarto lugar, Hartsock afirma que el punto de vista feminista es una posición social que se adquiere, no viene dada de antemano, sino que requiere ciertos esfuerzos políticos precisos para ser alcanzada. En efecto, el punto de vista contribuye a revelar las relaciones de poder que subyacen a ciertos arreglos de género en contextos concretos, pero ¿Cómo lo hace? ¿Cuáles son las estrategias para poner de manifiesto las jerarquías e injusticias? ¿Cómo se logra que los sujetos puedan hablar de "injusticia" en el marco de un sistema de género dominante que condiciona la manera de ver y estar en el mundo? Hartsock, nuevamente, apela a Marx para dar cuenta de estos interrogantes: según este filósofo, la formación de un punto de vista supone un cambio en la 
relación con "lo real", es decir, con las formas tradicionales de ver y participar en el mundo. En lugar de pensar en el sistema como dado, se trata de buscar sus "puntos de quiebre", las dinámicas que resulten problemáticas y que den cuenta de la no armonía o de los conflictos que el sistema genera. Para Marx, ese punto de quiebre se puede hallar en la experiencia de los actores que tienen una posición desventajosa en el sistema. Con esto como base, Hartsock afirma que examinar el sistema de género desde la mirada masculina, es decir, desde la posición de aquellos cuyo trabajo es valorado y reconocido positivamente, no genera información contundente sobre las distorsiones del sistema, pues esta perspectiva obtiene ventajas de los arreglos de género existentes y aboga por su reproducción. En cambio, la experiencia de quienes no son reconocidos y cuyas labores son vistas como inferiores sî puede llegar a informar sobre contradicciones, injusticias o subordinaciones que provienen de una posición de vulnerabilidad, puesto que sobre esta no recaen los beneficios del sistema y, por ello, desde allí se pueden comenzar a percibir sus fallos.

Es posible señalar que la tesis anterior encuentra su fundamento en la noción de experiencia: siguiendo a Nancy Hirschmann, las teóricas del punto de vista feminista parten de pensar en la realidad como un proceso en curso, en movimiento (Hirschmann 2004, 322); como las relaciones sociales no son estáticas y la experiencia no es unívoca, sino que se encuentra atravesada por diversas posiciones sociales, se puede pensar en la posibilidad de que surjan sujetos cuestionadores del sistema. Las diferentes relaciones que se 
entablan con el mundo permiten la movilidad y la aparición de lenguajes y prácticas que se oponen al status quo. Para las teóricas del punto de vista, atender a la experiencia de las mujeres, que es desventajosa en el sistema de género configurado en términos del punto de vista masculino, puede proveer información nueva sobre el sistema; información que revele sus desarmonías y violencias. Y se enfatiza en el "puede" porque el hecho de ser mujer no implica inmediatamente la adquisición del punto de vista feminista, esto es, la aparición de la posición cuestionadora del sistema de género. El ser mujer guarda potencialmente el punto de vista feminista, pero no es su garantía; para llegar a él, es preciso adquirir nuevos lenguajes, nuevas prácticas y, sobre todo, nuevas miradas que se ganan en la discusión compartida, en la puesta en común de experiencias y en la práctica política. ${ }^{54} \mathrm{La}$ idea de "mirada" resulta central aquí: en palabras de Hirschmann, "la adopción de un punto de

54 En relación con el modo en que se adquiere el punto de vista feminista, es preciso señalar a la dimensión histórica del feminismo de segunda ola, que es la corriente en la que se inscriben las reflexiones de la metodología del punto de vista. De acuerdo con Alix Kates Shulman, en la segunda mitad del siglo xx se comenzaron a formar los llamados "grupos de conciencia", los cuales tenían como fin reunir a diferentes mujeres para hablar de sus vidas personales y de sus relaciones con los hombres. Muchas de estas mujeres habían sido violadas, habían sufrido de algún tipo de acoso o vivían situaciones familiares y domésticas hostiles. Esto resulta importante en la medida en que permite comprender cómo, en la práctica, ha funcionado el proceso de creación del "punto de vista" como un ejercicio colectivo de "puesta en común" que permite ubicar la experiencia, por un lado, como parte de un sistema de géneros con consecuencias reales sobre las personas involucradas y, por otro, como un punto de partida para hallar las "fisuras" de lo que se presenta como armónico y "natural". Para una revisión de la historia de los grupos de conciencia y de la corriente del feminismo radical que se comenzó a gestar allí, ver Shulman (1980). 
vista feminista particular permite ganar un entendimiento del mundo 'menos parcial y perverso' [...] la confluencia de una variedad de puntos de vista feministas revela diferentes aspectos de la 'verdad', diferentes ángulos en la búsqueda de claridad, diferentes piezas de una imagen más amplia” (Hirschmann 2004, 322).

En últimas, la metodología del punto de vista feminista permite pensar en lo real desde diferentes ángulos y, con ello, cuestionar la visión hegemónica dada desde el punto de vista masculino; como bien lo señala Donna Haraway, "la visión es siempre una cuestión del poder para ver -y quizás de la violencia implícita en nuestras prácticas visuales" (Haraway 2004, 90). En un sistema de género en el que lo femenino se considera inferior o no se reconoce en términos positivos (o sólo se reconoce en términos positivos cuando se ajusta a la mirada masculina), la visión está estructurada desde lo masculino, en el sentido en que las categorías desde las que se interpreta, entiende y vive el mundo contribuyen a la reproducción del sistema de dominación. La puesta en circulación de nuevas categorías conduce a nuevas formas de ver; el punto de vista feminista tiene como objetivo, justamente, atender a la experiencia desventajosa de las mujeres para crear nuevas categorías que pongan de manifiesto la violencia inherente al sistema de género. ${ }^{55}$ En este proceso, la mirada cambia: el

$55 \mathrm{Y}$, en este sentido, enfocarse en la experiencia femenina no sólo contribuye a entender el punto de vista femenino, sino el sistema en general: desde la posición desventajosa ocupada por las mujeres se pueden advertir las lógicas del sistema desde el punto de vista de quienes tienen menos privilegios en él. En otras palabras, la experiencia femenina permite ver otra cara del sistema, en la 
sistema se percibe de otra manera y la visión se amplía, al no considerar a lo masculino como la única forma posible de pensar y estar en el mundo. ${ }^{56}$ De ahí que el último elemento identificado por Hartsock como central en la constitución del punto de vista feminista sea su "rol liberador" (Hartsock

que se revelan injusticias, violencias y distorsiones que se ocultan cuando se está en la posición de lo masculino. Bowell afirma que "[...] ciertas posiciones sociopolíticas ocupadas por las mujeres (y por extensión, por otros grupos que carecen de privilegios económicos y sociales) pueden llegar a ser lugares de privilegio epistemológico y, con ello, puntos de partida provechosos para generar preguntas no sólo sobre quienes son social y políticamente marginales, sino sobre aquellos que, en relación con sus privilegios sociales y políticos, ocupan la posición de opresores” (Bowell 2011). La experiencia femenina es un lugar potencialmente provechoso para examinar al sistema de género y sus modos de operar.

56 Para Haraway, es preciso tener precaución con esta idea de que atender la experiencia de las mujeres permite desplazar la visión de una perspectiva dominada por la mirada masculina, a una más amplia que posibilite pensar en otras formas de ver y estar en el mundo. Si bien Haraway está comprometida con esta tesis, también señala que "los puntos de vista de los subyugados no son posiciones inocentes” (Haraway 2004, 88), es decir, también involucran intereses y posiciones sociales precisas que deben ser puestas de manifiesto, con el objetivo de clarificar desde qué posición se interpreta y cuestiona el sistema. A pesar de que la posición de "los subyugados" también es parcial, las teóricas del punto de vista feminista defienden que examinar dicha posición en relación con la de los “dominantes” permite tener un panorama más amplio de las lógicas del sistema y, sobre todo, permite cuestionarlo y problematizarlo. Por otra parte, siguiendo las reflexiones de Hartsock, la metodología del punto de vista no se piensa como la vía para explicar la totalidad de los fenómenos, sino que se plantea como una perspectiva que pretende capturar ciertas realidades del mundo social sin desconocer que existen otras que se quedan por fuera (Hartsock 1997, 371). En este sentido, las teorías feministas que recurren a dicha metodología "iluminan" ciertos aspectos de la realidad, sin negar la posibilidad de que las realidades que se quedan en "la oscuridad" no puedan ser abordadas también y no sean igualmente legítimas. Por esta razón, no se trata de desconocer el hecho de que el punto de vista de las mujeres también es parcial, sino de revelar cómo desde esa parcialidad se puede obtener otra visión de la realidad que muestre que la hegemonía del punto de vista masculino no es el único mundo posible ni la única forma de estar en el mundo. 
2004, 37). Revelar las relaciones de poder y violencias que subyacen al sistema de género existente y, por esto, buscar nuevas formas de ver y nuevas experiencias son procesos que conducen a la pretensión de cambiar el estado de cosas actual por uno en el que se pueda hablar de relaciones justas. Este es el elemento normativo del punto de vista feminista: al enfocarse en la experiencia que está en desventaja en las dinámicas del sistema, se apunta a cambiar al sistema mismo, a pensar más allá de las relaciones de dominación que se entablan en él (Hartsock 2004, 39).

En resumen, los cinco puntos centrales del punto de vista feminista son: (i) las relaciones de los sujetos con las condiciones materiales de existencia conforman las experiencias sociales de los hombres y de las mujeres, es decir, perfilan sus modos de estar, participar y relacionarse con el mundo; (ii) el sistema de género que asigna experiencias distintas a mujeres y hombres es un sistema de dominación que involucra jerarquías y relaciones de poder desde las cuales lo femenino es visto como inferior mientras lo masculino se asocia con lo superior; (iii) en ese sistema de dominación de género, la visión del género dominante (el masculino) condiciona y estructura la experiencia del género dominado (el femenino); (iv) el punto de vista feminista se define como una posición social adquirida a partir de esfuerzos políticos concretos; (v) el punto de vista feminista es una metodología que le apuesta a la liberación, es decir, a la estructuración de relaciones de género justas y no jerárquicas. Estas cinco características dan una idea de cómo esta metodología contribuye a la reflexión sobre las enemigas y los enemigos en bahía Portete. 
En primer lugar, se puede decir que la diferencia en los métodos de intimidación usados por los paramilitares para atacar a mujeres y a hombres debe ser considerada, puesto que puede descansar sobre experiencias diferentes en el marco de los conflictos políticos. En otros términos, es posible que la manera de enfrentarse a los enemigos se encuentre atravesada por formas de interpretar y estar en el mundo que repercuten en el modo como se reconoce y se define al otro en el momento de defender la forma de vida propia. El punto de vista feminista permite llamar la atención sobre estos asuntos, por una parte, al mostrar la pertinencia de introducir la diferencia sexual en casos en los que la posición de las mujeres se presenta como diferente a la de los hombres $y$, por otra parte, al propiciar el examen de esa diferencia, es decir, al promover la indagación sobre las lógicas sociales, las prácticas, la violencia, las distorsiones que pueden estar en la base de la distinción hombre-mujer en determinados contextos. Bajo esta perspectiva, no se trata de asumir que en el caso de bahía Portete la diferencia sexual es un elemento central, sino de pensar en la distinción en los métodos de intimidación como un posible síntoma de concepciones del enemigo y de la enemistad que no se han revelado aún y que merecerían un examen riguroso en el marco de la teoría del conflicto de Schmitt, en tanto que pondrían de manifiesto nuevas formas de pensar en el enemigo y de definir al otro que rebasan los límites del concepto de lo político neutral ante el género.

En segundo lugar, la metodología del punto de vista feminista aplicada al caso de bahía Portete revelaría tipos de 
violencia, relaciones de poder y jerarquías que se vinculan con las diferentes experiencias en el conflicto. La violencia ejercida por los paramilitares en contra de las mujeres wayús puede ser un indicio del sistema de dominación que está en la base de las experiencias de género y que estructura la manera como hombres y mujeres participan en la disputa política. En este sentido, el punto de vista feminista posibilita centrar la atención en cómo las relaciones de género dominantes definen los tipos de enemistad y de guerra en los conflictos; la metodología invita a examinar las experiencias femenina y masculina y las relaciones entre ellas como elementos estructurantes de las enemistades y de la forma de reconocer al otro en medio de los conflictos. De igual manera, el punto de vista permite preguntarse por el carácter del poder que se ejerció por los hombres paramilitares en contra de las mujeres wayús: en un conflicto no acotado en el que los paramilitares apuntaban a destruir la forma de vida wayú absolutamente, ¿por qué escoger la violencia sexual para enfrentarse a las enemigas? ¿Revela esto relaciones de poder y experiencias sociales que no se agotan en el concepto de enemigo ciego ante la diferencia de género?

Por último, el punto de vista feminista permite cuestionar la teoría de Schmitt a partir de la experiencia femenina en el conflicto. Centrar la mirada en cómo las mujeres wayús participaron en la disputa y, en particular, enfocarse en la manera como fueron vulneradas por los enemigos posibilita el planteamiento de preguntas que conducen a un entendimiento más amplio del conflicto y de lo que está en juego en el momento de enfrentarse con el otro amenazante de la forma 
de vida propia. Puesto en términos de Haraway, el punto de vista feminista abre la posibilidad de articular nuevas formas de ver el conflicto, de plantear nuevas categorías que permitan ampliar el panorama de la noción de enemistad y problematizar la idea de que las experiencias de género no impactan en las lógicas de lo político. En últimas, las reflexiones que se plantean desde el punto de vista feminista contribuyen a señalar la relevancia de la experiencia de género para entender desde una perspectiva más amplia los procesos que se llevan a cabo cuando el antagonismo político de Schmitt se desarrolla entre mujeres y hombres. Pero, además de ampliar la visión y de sugerir que el concepto de lo político debería ser sensible ante la experiencia de género en casos en los que se muestra como relevante para entender el carácter de la enemistad (como es el caso de bahía Portete), el punto de vista feminista también apunta a un examen de la violencia y de las relaciones de poder que subyacen a las experiencias sociales de género concretas. En este sentido, estudiar el caso de bahía Portete con las herramientas de la teoría de Schmitt y del punto de vista feminista requeriría el análisis del tipo de violencia que se efectuó allí, de cómo esta descansa sobre experiencias relativas al género, constituidas y reproducidas socialmente, y de la enemistad que se revela en relación con ella. ${ }^{57}$

57 Utilizar la metodología del punto de vista feminista para estudiar el caso de Bahía Portete en relación con el concepto de lo político se sustentaría sobre un compromiso con la liberación. Al entender las lógicas de poder y de violencia que operan en la estructuración de las experiencias de género definitorias de los enemigos en el conflicto se apunta a una transformación de la estructura de género que se base en la justicia y en la reducción de la violencia. 


\section{La violencia sexual en contra de las mujeres wayús: el significado social de los cuerpos y el reconocimiento de las enemigas wayús}

Ramazanoglu y Holland afirman que "las aproximaciones que adoptan un punto de vista feminista varían porque hay más de una teoría feminista y más de una posición epistemológica feminista" (Ramazanoglu y Holland 2002, 64). En esta dirección, si el objetivo es plantear la pregunta por la diferencia sexual en el marco del concepto de lo político y del caso de bahía Portete, no sólo basta con proponer que se puede pensar en el conflicto a partir de un punto de vista articulado desde la experiencia de género que problematice la noción de enemistad y la del reconocimiento del enemigo a la luz de la diferencia que parece establecerse entre mujeres y hombres; también es preciso "dotar de contenido" a los términos desde los cuales se va a plantear el asunto. ¿Qué significaría "experiencia de género" en el contexto de la masacre de bahía Portete? ¿En qué radicaría la diferencia entre mujeres y hombres allí? En últimas, ¿cuáles serían los términos desde los que se plantearía la cuestión de la diferencia sexual en el marco de la masacre de bahía Portete? El modo en que el feminismo radical de Catharine Mackinnon utiliza las herramientas del punto de vista feminista para construir su teoría puede proporcionar elementos importantes en relación con la pregunta por la diferencia sexual en el caso de las enemigas y los enemigos wayús. En particular, el aporte de Mackinnon está dirigido a ubicar en el centro de la diferencia sexual la idea de que la experiencia de género se define en términos de los significados sociales de los cuerpos y, en 
este sentido, un estudio de la diferencia entre los métodos de intimidación llevados a cabo en contra de las mujeres y los hombres wayús tendría que tomar como punto de partida la experiencia del cuerpo y las violencias y relaciones de poder que se derivan de ella.

La reflexión de Mackinnon también recurre al marxismo como punto de apoyo: para esta filósofa, marxismo y feminismo ${ }^{58 ~ "[. . .] ~ o f r e c e n ~ e x p l i c a c i o n e s ~ d e ~ c o ́ m o ~ l a s ~ d i s p o s i c i o-~}$ nes sociales de disparidad pautada y acumulativa pueden ser internamente racionales y sistemáticas, pero injustas. Ambos son teorías del poder, de sus consecuencias sociales y de su injusta distribución. Ambos son teorías de la desigualdad social" (Mackinnon 1989, 24). Tanto en el marxismo como en el feminismo persiste la idea de que las diferencias entre proletario y capitalista o entre mujer y hombre no son arbitrarias, sino que, por el contrario, responden a estructuras sociales que definen posiciones desde las cuales percibir, comprender y participar en el mundo. Pero, en lugar de hablar de diferencia, marxismo y feminismo prefieren recurrir al término desigualdad, pues no es sólo que existan diversas maneras de ver e interactuar con el entorno, sino que esas diferencias suponen desigualdad en la distribución del poder social. El capitalista, como dueño legítimo de los medios de producción, tiene poder sobre la vida del obrero, debido a que la fuerza de trabajo del último forma parte integrante en la constitución de la riqueza del primero. Y, en el caso de la

58 Con “feminismo", Mackinnon se refiere al feminismo radical. De ahora en adelante, seguiré la misma terminología de la autora. 
desigualdad de géneros, según Mackinnon, el hombre tiene el poder de definir y disponer del cuerpo femenino y la mujer carece de poder sobre su propia corporalidad. ${ }^{59}$

La propuesta de Mackinnon se plantea desde un cambio de categorías, o de mirada (como diría Haraway): mientras el marxismo identifica al trabajo como el proceso social básico a partir del cual se articulan las relaciones humanas, el feminismo supone que la sexualidad es ese proceso articulador y determinante de la interacción social. En otras palabras, para el marxismo las interacciones laborales son el momento en el que se ponen en juego las relaciones de poder y, por ende, en el que la desigualdad se hace evidente; el feminismo, por su parte, considera que la desigual distribución del poder encuentra su sentido en las relaciones sexuales, entendidas como la interacción corporal entre hombres y mujeres. ${ }^{60}$ En este sentido, Mackinnon rechaza la propuesta marxista por insuficiente a la hora de dar cuenta del sistema de desigualdad de género. El trabajo como categoría central de las estructuras sociales funciona como explicación sistemática

59 En la teoría de Mackinnon, y desde la perspectiva de las teóricas del punto de vista en general, hablar de "hombre" y "mujer" no remite a mujeres y hombres concretos y particulares, sino a puntos de vista. Es decir, a modos de estar en el mundo, a formas de vida que se propician desde estructuras sociales determinadas, pero que son maleables y cambiantes. Entonces, el punto no es que todas las mujeres carezcan de poder social y todos los hombres lo posean completamente; la distribución del poder varía de contexto en contexto. Lo que se quiere señalar aquí es que sí hay unas estructuras que son desiguales en tanto que están articuladas desde la distribución inequitativa del poder.

60 Sobre Mackinnon también recae la crítica de Butler, según la cual el feminismo parte de una experiencia de género heterosexual. 
del capitalismo y las relaciones proletario-capitalista y, eventualmente, esto puede dar luces sobre ciertas experiencias femeninas (como se hace en la teoría de Nancy Hartsock). No obstante, de acuerdo con Mackinnon, el concepto de trabajo no agota la experiencia femenina; todo lo contrario: desconoce relaciones que, para esta pensadora, son centrales en la constitución de lo que es una mujer y de lo que define al hombre. La propuesta de Mackinnon apunta a buscar un concepto que cumpla el mismo papel que el trabajo en el marxismo, pero, esta vez, para una conceptualización del feminismo. Entonces, aunque rechaza los postulados marxistas que explican la desigualdad, Mackinnon toma la estructura "formal" de esta teoría para articular una propuesta de corte feminista. Se mantiene la noción de experiencia como punto de partida para el análisis y se conserva la idea del sistema de distribución desigual del poder, pero se desplaza la mirada de las relaciones de producción a las relaciones sexuales.

Para Mackinnon, "una teoría es feminista en la medida en que está convencida de que las mujeres han sido injustamente distintas de los hombres por el significado social de su cuerpo" (Mackinnon 1989, 84). En efecto, desde esta perspectiva, los significados sociales que se le atribuyen al cuerpo son los que perfilan lo que se piensa como femenino y como masculino y son los que articulan el sistema de desigualdad en la distribución del poder. Por un lado, Mackinnon es enfática en el hecho de que su concepción del cuerpo y de las relaciones que se establecen entre el cuerpo masculino y el femenino no es producto de determinantes biológicos; por el contrario, el cuerpo es un escenario de lucha social y de distribución del 
poder (Mackinnon 1989, 110). Por otro lado, tomando como base lo anterior, Mackinnon defiende que las concepciones sobre el cuerpo descansan en estructuras de desigualdad en la distribución del poder; de acuerdo con esto, la experiencia femenina se configura por la manera como el cuerpo de la mujer es definido, esquematizado y apropiado por parte del hombre. De ahí la desigualdad: mientras el hombre tiene el poder de disponer del cuerpo femenino y de definirlo, la experiencia de la mujer -la manera en que ella piensa y vive su cuerpo- depende del punto de vista masculino; lo que es la mujer se define y juzga en términos de lo masculino. Esta distribución del poder se traduce en violencia, en la medida en que el poder asignado al hombre le permite disponer del cuerpo de la mujer en beneficio de sus intereses; por esto, Mackinnon afirma: "no es sólo que los hombres traten mal a las mujeres, aunque a veces lo hacen, sino que de ellos depende hacerlo o no" (Mackinnon 1989, 170). El punto aquí es que, independientemente de si los hombres concretos hacen uso de su poder o no al violentar los cuerpos de las mujeres, el solo hecho de que la posibilidad de infrigir violencia corporal esté presente, sea plausible e inteligible, da cuenta del sistema de poder que está de fondo: un sistema que define a la masculinidad desde el poder sobre lo femenino.

Entonces, el punto de vista feminista configurado por Mackinnon tiene como centro la noción de sexualidad y, con ello, la de cuerpo. La experiencia de género y las estructuras de desigualdad se definen en términos de cómo se constituyen las nociones de feminidad y masculinidad alrededor de la experiencia corporal o, lo que es lo mismo, de la sexualidad. 
Este punto de vista permite dotar de contenido a la noción de diferencia sexual que se plantea a la luz del caso de bahía Portete, particularmente, porque, en virtud del énfasis en la sexualidad y en las relaciones que se establecen entre el cuerpo masculino y el femenino, la teoría de Mackinnon posibilita ubicar a la violencia sexual en el centro de la discusión sobre diferencia entre géneros. Siguiendo a Mackinnon, este tipo de violencia es una de las expresiones más contundentes del sistema de géneros y de la desigualdad que este implica; a través de la violencia sexual se graba el mensaje de quién tiene el poder por medio de la forma como lo hace efectivo. Usualmente, dice Mackinnon, se tiende a pensar en la violación sexual como un tipo de violencia que supone abuso de autoridad y fuerza física, pero esta concepción carece de una explicación del término "sexual". ¿Qué significa que una violencia sea sexual? En efecto, en la violación hay involucradas cuestiones de abuso de autoridad y vulneraciones físicas, pero su carga sexual no se agota allí; esta explicación, “además de no responder a la pregunta bastante obvia de que si es violencia y no sexo, por qué no se limitó a golpearla, este enfoque hacía imposible ver que la violencia es sexo cuando se practica como sexo" (Mackinnon 1989, 238), esto es, cuando la violencia que se ejerce está directamente relacionada con los significados sociales de los cuerpos femenino y masculino y con la desigualdad de poder que subyace a estos. El hecho de que el hombre tenga la capacidad de disponer del cuerpo de la mujer para violarlo pone de manifiesto el poder social del cuerpo masculino sobre el femenino. Por eso la violencia es sexual: porque se ejerce sobre el cuerpo 
y porque su fin es ratificar o demostrar quién tiene el poder sexual, es decir, el poder de apropiar y definir el cuerpo del otro, o en este caso, de la otra.

El concepto de sexualidad y, específicamente, el de violencia sexual le dan un lenguaje concreto a la diferencia sexual en el momento de estudiar a las enemigas y los enemigos wayús de bahía Portete: las mutilaciones de los órganos reproductivos, los grafitis y los mensajes que les enviaban los paramilitares a las lideresas wayús con el fin de intimidarlas para que renunciaran a la defensa de su forma de vida revelan el tipo de experiencia que operó allí y las relaciones de poder sobre las que se basaba. Por ejemplo, en la casa de una de las mujeres wayús se encontró esta amenaza: "quiero matarte a punta de monda [pene] por la boca, por la chucha [vagina] y el culo en especial mamacita arrecha" (Colombia, Centro Nacional de Memoria Histórica 2010, 87). El pene como órgano asociado a la masculinidad es utilizado aquí como un elemento amenazante hacia lo femenino que se asocia con la vagina. De la misma manera, no parece fortuito que los grafitis enfaticen tanto en los órganos sexuales de hombres y mujeres o que se asimile el pene con un arma de fuego que ataca directamente a la mujer representada a través de los senos y la vagina. En las representaciones gráficas y escritas de las amenazas de violación sexual se puede advertir un ataque a experiencias asociadas directamente con la "femineidad", con lo que socialmente se ha caracterizado como los rasgos centrales del cuerpo femenino. La relación de poder también se revela: los mensajes que los paramilitares les transmitieron a las mujeres wayús indican que tienen el poder para 
disponer y violentar sus cuerpos apelando a su masculinidad encarnada en la figura del pene. En este contexto, el caso de bahía Portete pone de presente cómo la enemistad que allí se gestó está directamente atravesada por la sexualidad; este es el reto que el caso le impone a Schmitt: si el concepto de lo político funciona como herramienta para entender los conflictos reales del mundo humano, no se puede pasar por alto que en la masacre de bahía Portete la sexualidad fue el elemento crucial a la hora de dar muerte al enemigo y, por esto, es un aspecto central en el momento de estudiar el tipo de enemistad que operó en ese caso.

\section{Conclusiones: ver el conflicto de bahía Portete desde la violencia sexual}

Si el punto de vista feminista muestra la pertinencia de proponer la noción de diferencia sexual como una clave de lectura para realidades que están presentes en el caso, pero que no es posible ver sin las herramientas de visión dadas por la noción de experiencia social y por la sensibilidad ante relaciones de poder ligadas al género, la propuesta de Mackinnon permite darle contenido a esas herramientas de visión al poner a la experiencia corporal como el centro de la diferencia y, más aún, de la desigualdad sexual. El punto de vista feminista posibilita afirmar que la diferencia entre hombres y mujeres en el caso de bahía Portete es un elemento crucial en la conceptualización del conflicto; la teoría de Mackinnon va un paso más allá, al ubicar la mirada en el cuerpo como el elemento definitorio de la diferencia sexual. Así, la cuestión a la que conducen las reflexiones anteriores puede ser puesta en 
estos términos: para Schmitt, "el enemigo es nuestra propia pregunta como persona” (Schmitt 1966, 118), es aquel que pone en cuestión la forma de vida propia y la existencia. De igual manera, siguiendo la sugerencia de Derrida, los métodos escogidos por el enemigo para dar muerte cuando los conflictos llegan a la guerra ponen de presente el carácter de la enemistad y, con ello, la manera como opera ese "poner en cuestión" la forma de vida del otro: si la enemistad es acotada, el otro se reconoce como un enemigo legítimo cuya forma de vida es legítima, a pesar de que sea una amenaza para $m i$; en este contexto, la violencia es regulada. En cambio, cuando la enemistad es absoluta, no se le reconoce al otro el derecho a defender su forma de vida y esto se traduce en la violencia extrema, en la eliminación física y absoluta del enemigo; la existencia del otro es puesta en cuestión de manera absoluta: el otro no merece existir. Lo que habría que preguntarse, tomando como herramientas los conceptos del punto de vista y de la teoría de Mackinnon, es ¿qué tipo de "puesta en cuestión” se da cuando la forma de atacar a la enemiga es la violencia sexual? En otras palabras, ¿cómo capturar un conflicto en el que la sexualidad parece ser crucial en el momento de acabar con otra forma de vida, en este caso, la wayú? ¿Qué tipo de conflicto se presenta allí? ¿Cómo cambia la conceptualización de lo político al introducir la noción de sexualidad?

Mackinnon afirma que, en el marco de los conflictos armados, "las mujeres son violadas como no lo son los hombres [y] muchas de estas violaciones son sexuales y reproductivas” (Mackinnon 1993, 88). En el caso particular de 
bahía Portete, habría que pensar cómo esa violencia sexual que recae sobre las mujeres entra a operar en las dinámicas de lo político. Puesto en otros términos, en un caso donde las mujeres son quienes se declaran públicamente como defensoras de su comunidad frente al enemigo paramilitar, ¿por qué la violencia sexual resulta ser el arma a partir de la cual se acaba con la existencia de las enemigas? Y ¿por qué no se recurre a los mismos métodos cuando se trata de los enemigos? Plantear estas cuestiones en el marco de la masacre de bahía Portete permite pensar que conceptos como los de experiencia de género, sexualidad y diferencia sexual pueden resultar útiles para articular nuevas miradas de lo político y la enemistad. El caso parece sugerir la importancia y la pertinencia de estudiar la violencia contra las enemigas como un factor que puede ser un síntoma de un tipo de enemistad que aún está por conceptualizar y que podría imponerle retos significativos a la conceptualización schmittiana. Introducir la diferencia sexual y ubicar a la sexualidad como el punto central de ella son movimientos conceptuales que dejan abierta la posibilidad de pensar en la violencia sexual como una forma de acabar y de reconocer al enemigo que no se ha considerado aún y que puede proporcionar nuevos elementos al concepto de lo político o incluso poner en cuestión muchos de sus supuestos. Lo sucedido en bahía Portete parece exigir nuevas formas de ver lo político: si se pretende dar cuenta de esta masacre, entender las dinámicas que operaron allí, el tipo de conflicto que se desarrolló, los modos de entender la enemistad, etc. Es preciso articular 
herramientas de visión que sean sensibles ante fenómenos como la violencia sexual o como las diferentes experiencias de género, los cuales parecen haber impactado en la naturaleza del conflicto y en los movimientos que adquirió lo político en este caso concreto. 


\section{Conclusiones La hermana y lo político}

Mackinnon se pregunta: “¿Cómo camina la historia por la vida de las mujeres, cómo piensa sus pensamientos? Si esta pregunta nunca se ha planteado, ¿no es posible que falte algo en la conceptualización no sólo de las mujeres, sino también de la historia y de la conciencia? El feminismo se preocupa por esto y altera la postura y la persona -el 'nosotros'- de quien teoriza, la práctica de la teoría como actividad, el análisis de la conciencia, la vida social y la relación entre ellos” (Mackinnon 1989, 83). Para Mackinnon, pensar en la historia desde una perspectiva que capture la experiencia femenina y su relación con la masculina tiene consecuencias sobre la manera, no sólo de pensar en la vida social, sino en la teoría, pues se les da un lenguaje a experiencias que no lo tenían a partir de nuevas categorías. Preguntarse por la experiencia de la mujer supone un cambio de mirada y una nueva forma de pensar y conceptualizar la historia, en la medida en que la relación de las mujeres con la vida material, con los procesos sociales y con el mundo circundante no se agota en las conceptualizaciones que han sido pensadas desde un punto de vista exclusivamente masculino o desde un marco neutral ante las experiencias de género. Por esta razón, el esfuerzo por conceptualizar la historia considerando la experiencia 
de género como central en sus procesos cambia la perspectiva y exige nuevos movimientos conceptuales que, o bien pueden enriquecer la teoría existente, o bien pueden exigir la articulación de nuevas teorías que respondan de manera más acertada a las demandas del género.

Esta forma de pensar en el feminismo y en sus modos de acercarse a la vida social y a la teoría es compatible con la noción de irreductibilidad de Derrida: la teoría de Schmitt proporciona un lenguaje para entender el caso de bahía Portete desde el conflicto, la enemistad y la guerra; sin embargo, se queda corta en el momento de dar cuenta de las diferencias internas que la misma comunidad wayú albergaba y que fueron cruciales en el desarrollo del conflicto y en el carácter absoluto que este adquirió. Para Derrida, la obsesión de Schmitt con la "pureza” de lo político, es decir, con el mantenimiento de un conflicto acotado, con reglas de juego claras y con enemigos definidos en términos de unidades políticas homogéneas no permite advertir que, en los conflictos reales, priman las enemistades no acotadas y la heterogeneidad al interior de las comunidades. Por eso, y con el fin de poner de presente la importancia del enemigo interno para entender los conflictos políticos, Derrida sugiere la noción de hermano, la cual muestra, por un lado, que las unidades políticas albergan conflictos internos que una teoría interesada en el conflicto no puede pasar por alto y, por otro, que la formación de lazos que homogenizan a las unidades políticas no es producto de la naturaleza, sino de procesos históricos y sociales concretos. El hermano entra a participar de la noción de irreductibilidad, puesto que con esta noción 
se intenta conceptualizar una realidad que ha sido descuidada por Schmitt, pero que merecería mayor atención si se quiere que lo político sea una herramienta para pensar los conflictos reales del mundo contemporáneo. Y, en efecto, el concepto de hermano es útil para acercarse a la masacre de bahía Portete, ya que posibilita estudiar la inserción de los paramilitares en las redes de parentesco wayú y la aparición de la figura de Chema Bala como coyunturas que propiciaron una enemistad absoluta en la que la forma de vida wayú fue negada y atacada sin concesiones de ningún tipo.

Pero el caso parece exigir la introducción de otro elemento que permita dar cuenta de la diferencia que existe en el momento de dar muerte a las enemigas y a los enemigos wayús. Siguiendo con el movimiento de la irreductibilidad propuesto por Derrida con base en el concepto de hermano, la diferencia en los métodos de intimidación usados por el enemigo paramilitar para atacar a mujeres y hombres se muestra como un elemento que puede plantear preguntas y retos importantes frente al concepto de lo político y a los modos como se reconoce al enemigo. Capturar estos asuntos conceptualmente sería un trabajo que está por examinarse y que requiere un lenguaje; el punto de vista feminista y su aplicación por parte de Mackinnon abren la posibilidad de centrar la mirada en las experiencias de género y de afirmar la relevancia de atender a ellas para pensar en lo político de manera más amplia. Derrida ya había planteado la propuesta de introducir la diferencia sexual como parte de las lógicas de conceptualización de los conflictos; el punto de vista feminista y la teoría de Mackinnon le dieron un lenguaje y 
una dirección a esas inquietudes de Derrida por la diferencia sexual en relación con la masacre de bahía Portete.

Tanto las teóricas feministas, como el filósofo francés, coinciden en señalar la pertinencia de pensar en la diferencia sexual como un elemento que exige al concepto de lo político nuevas herramientas de visión y de análisis. De hecho, Derrida es enfático en afirmar que la diferencia entre hombres y mujeres, al igual que la noción de hermano, le demandan a Schmitt salir de los límites impuestos por la pureza conceptual: el concepto de lo político no puede ser neutral ante las diferencias, pues esto implica ceguera frente a los diversos tipos de conflictos que se presentan en las sociedades contemporáneas. Por eso, la opción, tanto para Derrida como para las teóricas del punto de vista, sería “[...] inventar otros nombres y otros conceptos [...] trasladarse más allá de esta política sin dejar de intervenir en ella para transformarla" (Derrida 1998b, 183), es decir, adquirir nuevas herramientas que sean útiles para examinar los conflictos reales y que doten de sensibilidad al concepto frente a las realidades que lo enriquecen o lo ponen en cuestión. La ceguera debe ser superada con el fin de atender a violencias, enemistades y conflictos que atraviesan lo político, pero que se pasan por alto en un examen que se remite meramente a la pureza conceptual. Entonces, así como en el caso del hermano, la introducción de la diferencia sexual como parte de lo político formaría parte del mismo movimiento de la irreductibilidad, del intento por darle un lenguaje a realidades aún no vistas $y$, con base en esto, crear herramientas de visión adecuadas. 
Derrida propone el concepto de "hermana" como aquel a partir del cual se puede comenzar a pensar en lo político con sexo y en las nuevas perspectivas que eso genera. Pero, ¿cómo definir a la "hermana” ? ¿Cómo construir ese nuevo concepto? Y, más aún, ¿cómo ponerlo a dialogar con lo político? En este texto se procuró mostrar que, para la comprensión del caso de bahía Portete, es preciso atender a las diferencias internas de la comunidad wayú; en particular, a aquellas diferencias ligadas a los enemigos que surgen en el seno de la misma comunidad y, muy especialmente, a las diferencias de género articuladas alrededor de los significados sociales de los cuerpos. Bajo esta perspectiva, introducir el concepto de hermana en la reflexión sobre el conflicto y la guerra es pertinente y central porque supone pensar en la diferencia sexual como un elemento que podría impactar en lo político, en las formas de enemistad que se articulan en diversos contextos y en la manera como se reconoce al enemigo. Sin embargo, esta monografía se concentró en mostrar la pertinencia de la noción de hermana y a dotar de dirección y contenido las inquietudes de Derrida. Aún queda por pensar qué significaría ese nuevo concepto de hermana, cómo impactaría concretamente en lo político, qué lógicas introduciría, cuáles cuestionaría. Por eso, las preguntas de Derrida siguen vigentes para futuras investigaciones: ¿y la hermana? ¿Cómo definirla? ¿Cómo ponerla a dialogar con lo político? 



\section{Bibliografía}

Alcoff, Linda. "Feminismo cultural versus posestructuralismo: la crisis de la identidad en la teoría feminista". En Nuevas direcciones, editado por Marysa Navarro y Catharine Stimpson, 65-106. Buenos Aires: FCE. 2001.

Amorós, Celia. "Presentación (que intenta ser un esbozo del estatus questionis)". En Feminismo y filosofía, editado por Celia Amorós, 9-112. Madrid: Editorial Síntesis, 2000. Applied Philosophy. Consultado octubre 6, 2013. http:// en.citizendium.org/wiki/Applied_Philosophy Arendt, Hannah. Hombres en Tiempos de Oscuridad. Barcelona: Gedisa Editorial, 1990.

Beardsworth, Richard. Derrida y lo político. Buenos Aires: Prometeo Libros, 2008.

Bennington, Geoffrey y Jacques Derrida. "La política”. En Jacques Derrida, 237-248. Madrid: Ediciones Cátedra, 1994. Bowell, Tracy. Feminist Standpoint Theory. Consultado marzo 9, 2015. http://www.iep.utm.edu/fem-stan/\#H1 Butler, Judith. Elgénero en disputa. El feminismo y la subversión de la identidad. Barcelona: Paidós, 1990.

Collins, Patricia. "Learning from the Outsider Within: The Sociological Significance of Black Feminist Thought". En The Feminist Standpoint. Theory Reader. Intellectual 
and Political Controversies, editado por Sandra Harding, 103-126. New York: Routledge, 2004.

Colombia, Centro Nacional de Memoria Histórica. La masacre de Babia Portete: Mujeres Wayun en la mira, coordinado por Gonzalo Sánchez. Bogotá: Ediciones Semana, Centro Nacional de Memoria Histórica, Taurus, 2010.

Colombia, Centro Nacional de Memoria Histórica. Mujeres y guerra. Víctimas y resistentes en el Caribe colombiano, coordinado por Gonzalo Sánchez. Bogotá: Ediciones Semana, Centro Nacional de Memoria Histórica, Taurus, 2011.

Colombia, Centro Nacional de Memoria Histórica. ¿̨ué es el Centro Nacional de Memoria Histórica? Consultado septiembre 23, 2013. http://www.centrodememoriahistorica.gov.co/somos-cnmh/que-es-el-centro-nacionalde-memoria-historica

Corbetta, Juan Carlos. "La política y lo político. De Carl Schmitt a Julien Freund”. En Carl Schmitt. Su época y su pensamiento, editado por Jorge Dotti y Jorge Pinto, 229-251. Buenos Aires: Editorial Universitaria de Buenos Aires, 2002.

Cornell, Ducilla. "The Violence of the Masquerade". En Jacques Derrida: Critical Assessments of Leading Philosophers, editado por Zeynep Direk y Leonard Lawlor, Vol. III. 163-179. London: Routledge, 2002.

Critchley, Simon. "Desconstrucción y pragmatismo: ¿es Derrida un ironista privado o un liberal público?”. En Desconstrucción y pragmatismo, editado por Chantal Mouffe, 45-85. Buenos Aires: Paidós, 1998. 
Derrida, Jacques. "Notas sobre desconstrucción y pragmatismo". En Desconstrucción y pragmatismo, editado por

Chantal Mouffe, 151-170. Buenos Aires: Paidós, 1998a.

Derrida, Jacques. Políticas de la amistad: el oído de Heidegger. Madrid: Trotta, 1998b.

Desconstrucción y pragmatismo, editado por Chantal Mouffe. Buenos Aires: Paidós, 1998.

Desde el desierto. Notas sobre paramilitares y violencia en territorio Wayun de la Media Guajira, editado por Karmen Ramírez. Maicao: Cabildo Wayúu Nóuna de Campamento, Colección Wounmainka, 2007.

Dotti, Jorge. "El visitante de la noche. En torno a la presencia de Max Stirner en el pensamiento de Carl Schmitt". En Carl Schmitt. Su época y su pensamiento, editado por Jorge Dotti y Jorge Pinto, 13-29. Buenos Aires: Editorial Universitaria de Buenos Aires, 2002.

Fernández Vega, José. “A proximaciones al enemigo”. En Carl Schmitt. Su época y su pensamiento, editado por Jorge Dotti y Jorge Pinto, 43-55. Buenos Aires: Editorial Universitaria de Buenos Aires, 2002.

Guerra, Weildler. La disputa y la palabra. La ley en la sociedad wayun. Bogotá: Ministerio de Cultura, 2002.

Haraway, Donna. "Situated Knowledges: The Science Question in Feminism and the Privilege of Partial Perspective". En The Feminist Standpoint. Theory Reader. Intellectual and Political Controversies, editado por Sandra Harding, 81101. New York: Routledge, 2004.

Harding, Sandra. "Introduction". En The Feminist Standpoint. Theory Reader. Intellectual and Political Controversies, 
editado por Sandra Harding, 1-15. New York: Routledge, 2004.

Harding, Sandra. The Feminist Standpoint Theory Reader: Intellectual and Political Controversies. New York: Routledge, 2004.

Hartsock, Nancy. "Comment on Hekman's 'Truth and Method:

Feminist Standpoint Theory Revisited': Truth or Justice?" Signs 22.2 (1997): 367-374.

Hartsock, Nancy. "The Feminist Standpoint: Developing the Ground for a Specifically Feminist Historical Materialism”. En The Feminist Standpoint. Theory Reader. Intellectual and Political Controversies, editado por Sandra Harding, 35-53. New York: Routledge, 2004.

Herrera, Wilson. Political Guilt, Forgiveness and the Duty to Remember. New York: Binghamton University, 2008.

Herrero, Monserrat. El nomos y lo político: la filosofía política de Carl Schmitt. Pamplona: Ediciones Universidad de Navarra (Eunsa), 1997.

Hirschmann, Nancy. "Feminist Standpoint as Postmodern Strategy". En The Feminist Standpoint. Theory Reader. Intellectual and Political Controversies, 317-332. New York: Routledge, 2004.

Holmes, Stephen. Anatomía del antiliberalismo. Madrid: Alianza, 1999.

Kaldor, Mary. Las nuevas guerras : la violencia organizada en la era global. Barcelona: Editorial Tusquets, 2001.

Kamuf, Peggy. "Différance”. En A Derrida Reader. Between the Blinds, editado por Peggy Kamuf, 61-77. New York: Columbia University Press, 1991. 
Kamuf, Peggy. "Deconstruction and Feminism”. En Jacques Derrida: Critical Assesments of Leading Philosophers, editado por Zeynep Direk y Leonard Lawlor, Vol. III, 118-138. London: Routledge, 2002.

Laclau, Ernesto. "Desconstrucción, pragmatismo y hegemonía”. En Desconstrucción y pragmatismo, editado por Chantal Mouffe, 97-136. Buenos Aires: Paidós, 1998.

Mackinnon, Catharine. Hacia una teoría feminista del Estado. Madrid: Ediciones Cátedra, 1989.

Mackinnon, Catharine. "Crímenes de guerra, crímenes de paz”. En De los derechos humanos. Las conferencias Oxford Amnesty de 1993, editado por Stephen Shute y Susan Hurley. Madrid: Trotta, 1993.

Mancuso, Alessandro. Relaciones de género entre los Wayúu:estado de la investigación y nuevos campos de análisis. Consultado octubre 4, 2013. http://jieyuuwayuu.blogspot. com/2007/09/relaciones-de-gnero-entre-los-wayu.html Massot, Vicente Gonzalo. “¿Por qué Schmitt?”. En Carl Schmitt. Suépoca y su pensamiento, editado por Jorge Dotti y Jorge Pinto, 79-87. Buenos Aires: Editorial Universitaria de Buenos Aires, 2002.

Meier, Heinrich. Carl Schmitt, Leo Strauss y el concepto de lo político. Sobre un diálogo entre ausentes. Buenos Aires: Katz Editores, 2008.

Mouffe, Chantal. "Desconstrucción, pragmatismo y la política de la democracia”. En Desconstrucción y pragmatismo, editado por Chantal Mouffe, 13-33. Buenos Aires: Paidós, 1998. 
Mouffe, Chantal. "Carl Schmitt y la paradoja de la democracia liberal”. En La paradoja democrática, 51-72. Barcelona: Editorial Gedisa, 2003a.

Mouffe, Chantal. "Para un modelo agonístico de democracia". En Laparadoja democrática, 93-118. Barcelona: Editorial Gedisa, 2003b.

Mouffe, Chantal. En torno a lo político. Buenos Aires: FCE, 2009. Mujeres violadas en la dictadura chilena rompen su silencio con historias dramáticas. Consultado octubre 6, 2013. http://informe21.com/chile/mujeres-violadas-dictadurachilena-rompen-su-silencio-historias-dramaticas

Narayan, Uma. "The Project of Feminist Epistemology: Perspectives from a Nonwestern Feminist". En The Feminist Standpoint. Theory Reader. Intellectual and Political Controversies, 213-224. New York: Routledge, 2004.

Ochoa, María. Horror sin nombre. Impacto de la entrada de los paramilitares en territorio wayú. Bogotá: Universidad de los Andes, 2011.

Platón. “Lisis”. En Diálogos I, 271-316. Madrid: Editorial Gredos, 1985.

Poovey, Mary. "Feminismo y deconstrucción”. En Nuevas direcciones, editado por Marysa Navarro y Catharine Stimpson, 47-64. Buenos Aires: FCE, 2001.

Ramazanoglu, Caroline y Holland, Jane. "From truth/reality to knowledge/power. Taking a feminist standpoint”. En Feminist Methodology. Challenges and Choices, 60-79. Londres: Sage Publications, 2002.

Romero, Mauricio. Paramilitares y autodefensas. 1982-2003. Bogotá: Editorial Planeta, 2003. 
Rorty, Richard. "Derechos Humanos, racionalidad y sentimentalidad". En De los derechos humanos. Las conferencias Oxford Amnesty, editado por Stephen Shute y Susan Hurley, 117-136. Madrid: Trotta, 1998a.

Rorty, Richard. "Notas sobre desconstrucción y pragmatismo".

En Desconstrucción y pragmatismo, editado por Chantal Mouffe, 35-43. Buenos Aires: Paidós, 1998b.

Salas, Ángela. Resentimiento en el paramilitarismo: análisis del discurso de Carlos Castaño Gil. Bogotá: Editorial Universidad del Rosario, Colección Ópera Prima, 2008.

Schmitt, Carl. "Teología política”. En Carl Schmitt, teólogo de la política, editado por Héctor Orestes. México: FCE, 1933. Schmitt, Carl. "El concepto de lo político". En Héctor Orestes (ed.), Carl Schmitt, teólogo de la política, 167-223. México: FCE, 1939.

Schmitt, Carl. Teoría del partisano. Acotación al concepto de lo político. Madrid: Instituto de Estudios Políticos, 1966.

Schmitt, Carl. "El nomos de la tierra. En el derecho de gentes del 'Jus publicum europaeum'“. En Héctor Orestes (ed.), Carl Schmitt, teólogo de la política, 461-500. México: FCE, 2001.

Serrano, Enrique. Consenso y conflicto. Schmitt y Arendt. La definición de lo político. Medellín: Editorial Universidad de Antioquia, 2002.

Shulman, Alix Kates. "Sex and Power: Sexual Bases of Radical Feminism”. Signs (Women: Sex and Sexuality 5 (1980): 590-604.

Strauss, Leo. "Comentario sobre el concepto de lo político de Carl Schmitt”. En Carl Schmitt, Leo Strauss y el concepto 
de lo político. Sobre un diálogo entre ausentes, editado por Heinrich Meier, 133-168. Buenos Aires: Katz Editores, 2008.

Suárez, María. Las mujeres fueron violadas durante el Holocausto. Consultado octubre 6, 2013. http://amecopress. net/spip.php?article7259

Uribe, Ángela. Petróleo, economía y cultura. El caso U'wa. Bogotá: Universidad del Rosario, Siglo del Hombre Editores, 2005.

Walzer, Michael. Guerras justas e injustas. Un razonamiento moral con ejemplos históricos. Barcelona: Editorial Paidós, 2001.

Young, Iris Marion. “Introducción”. En La justicia y la política de la diferencia, 11-30. Barcelona: Ediciones Cátedra, 2000. 

Este libro fue compuesto en caracteres

Stempel Garamond 12 puntos, sobre papel propal de 70 gramos y encuadernado con método Hot Melt, en mayo de 2015, en Bogotá, D. C., Colombia 